Fabíola de A. Salles Mariano

Corpo Cor:

entre o visual

e o tátil

São Paulo, 2012 



\section{Corpo Cor: entre o visual e o tátil}

Fabíola de Almeida Salles Mariano

Dissertação ECA/USP

Mestrado em Poéticas Visuais Orientador: Prof. Dr. Marco Garaude Giannotti 
Autorizo a reprodução e divulgação total ou parcial deste trabalho (exceto o conteúdo do DVD anexo), por qualquer meio convencional ou eletrônico, para fins de estudo e pesquisa desde que citada a fonte.

\section{Catalogação da Publicação Serviço de Documentação da Biblioteca da ECA/USP Escola de Comunicação e Artes da Universidade de São Paulo}

Mariano, Fabíola de Almeida Salles

Corpo cor: entre o visual e o tátil / Fabíola de Almeida Salles Mariano - São Paulo : F. A. S. Mariano, 2012.

146 p. : il. + DVD

Dissertação (Mestrado) - Escola de Comunicação e Artes / Universidade de São Paulo.

Orientador: Marco Garaude Giannotti

1. Artes Performativas 2. Percepção 3. Cor 4. Processo

I. Giannotti, Marco Garaude II.Título

CDD 21.ed. - 700 


Nome: Mariano, Fabíola de Almeida Salles Título: Corpo Cor: entre o visual e o tátil

Dissertação apresentada à Faculdade de Artes Plásticas da Escola de Comunicação e Artes da Universidade de São Paulo para obtenção do título de Mestre em Artes Visuais.

Aprovado em:

\section{Banca Examinadora:}

Prof. Dr.: Instituição:

Julgamento: Assinatura:

Prof. Dr: Instituição:

Julgamento: Assinatura:

Prof. Dr.: Instituição: Julgamento: Assinatura: 



\section{Agradecimento}

Agradeço imensamente a: Adriana, Alberto, Ana Maria e José Roberto Mariano, André Bella, Amelia Toledo, José Maria Carvalho, Leandro da Costa, Marcos Kaiser Mori, Maura Grimaldi, Monica Nador, Pedro Terra e a Tiago Lisboa.

Especialmente, com reconhecimento de sua atenção, agradeço aos professores Ana Maria de Araujo Tavares, Cristine Greiner, Carlos Alberto Fajardo e ao orientador deste trabalho Marco Garaude Giannotti.

Agradeço ainda à CAPES por apoiar esta pesquisa e produção. 

À minha avó. 



\section{Sumário}

\section{Parte I}

1. Introdução em Preto e Branco _ 16

2. Nuances e ciclos__ 21

2.1. ciclo vermelho — 27

2.2. ciclo verde 41

2.3. ciclo cinza-cor-de-pele 63

\section{Parte II}

3. A percepção como instrumento 84

3.1. Limiar: a opacidade do observador 86

3.2. Tátil-visual: o corpo performer _ 90

3.3. Pequenos movimentos: praticar percepção _ 92

3.4. A cor: o que vaza, o que infiltra __ 98

3.5. Atmosfera: meias-tintas 99

4. Experimentações cromáticas: corpo e pigmento 105

4.1. Uma pintura corporal na nação Kadiwéu 106

4.2. Antropometrias da Fase Azul de Yves Klein 109

4.3. Roda dos Prazeres de Lygia Pape 115

5. Dacapo 120

6. Referências 122

\section{Parte III}

6.1. Anexo 1: Entrevista com Monica Nador

6.2 Anexo 2: Conversa com José Maria Carvalho 138

6.3. Anexo 3: DVD com imagens de trabalhos citados 


\section{Resumo:}

MARIANO, F. A. S. M. Corpo Cor: entre o visual e o tátil. 2012. 146 f. Dissertação (mestrado em poéticas visuais) - Escola de Comunicação e Artes, Universidade de São Paulo, São Paulo, 2012.

A presente dissertação trata de três ciclos de trabalhos poéticos realizados entre 2009-2012 (vermelho, verde e cinza-cor-de-pele). A vivência do corpo com a cor nos três ciclos fez emergir, a partir de tonalidades e de balizas estipuladas a priori, processos de sensibilização do corpo no cotidiano, que foram entendidos em si como poética, bem como geraram desdobramentos: pinturas, objetos, ações... Nos ciclos, importaram as transformações que aconteceram no corpo, nas obras e num certo entre. Onde o dentro e o fora se encontram? O que separa um corpo do outro? No embate direto com a matéria, com o pigmento, a percepção tátil-visual foi ativada e, neste texto, entendida como chave conceitual para uma abordagem do corpo do artista nas artes visuais. Tal estudo deu-se principalmente a partir da Fenomenologia da Percepção de Maurice Merleau-Ponty, da Doutrina das Cores de Joahnn Wolfgang Goethe, do infra-mince descoberto por Marcel Duchamp e do Corpo do Artesão descrito por Pamela H. Smith. Além do estudo teórico, foram analisadas obras e manifestações culturais como auxílio reflexivo para toda a pesquisa: a pintura corporal do rito de passagem dos meninos da nação Kadiwéu, as Antropometrias da Fase Azul de Yves Klein e a performance e instalação Roda dos Prazeres de Lygia Pape. Ainda, fazem parte desta dissertação duas entrevistas com artistas que têm a cor e a atitude corporal diante do fazer artístico como foco de seus trabalhos.

Palavras chave: artes performativas, percepção, cor, processo. 


\section{Abstract:}

MARIANO, F. A. S. M. Body Color: between the visual and the tactile. 2012. 146 f. Dissertação (mestrado em poéticas visuais) - Escola de Comunicação e Artes, Universidade de São Paulo, São Paulo, 2012.

This essay analyzes three cycles of poetic works made between 2009-2012 (red, green and skin-gray color). The interaction of color and body in the three cycles emerged from hues and goals stipulated a priori, affecting the behavior of the body, what was perceived as poetry, in that they stimulated paintings, actions, objects... The main focuses of attention in each cycle were the transformations that took place in the body, in the pieces and somewhere inbetween. Where the inside and the outside toutch each other? What separates one body from the other? In direct confrontation with materials, with pigments, the visual-tactile perception was activated and, in this text, understood as a conceptual key of the artist's body in the visual-art's field. The conceptual approach was mainly driven by the Phenomenology of Perception by Maurice Merleau-Ponty, the Theory of Colors by Joahnn Wolfgang Goethe, the infra-mince discovered by Marcel Duchamp and the Body of the Artisan described by Pamela H. Smith. Besides the theoretical study, were analyzed some works and cultural manifestations: body painting of the rite of passage for boys in the nation Kadiwéu, the Antropometries of the Blue Period by Yves Klein and the performance and installation Roda dos Prazeres of Lygia Pape. Still part of this dissertation, two interviews with artists that have the color and human attitude as artistic focus.

Keywords: performance art, perception, color, process. 

Parte I 


\section{Introdução em Preto e Branco}

Preto: a contração minúscula e sutil da pupila é uma informação para todo o corpo que se contrai.

Branco: abertura da pupila e, sobre a cadeira, meu corpo se esparrama um pouco.

A presente dissertação é resultado da reflexão e compartilhamento do processo de produção de trabalhos poéticos que desenvolvi nos últimos anos. Para isto, foi realizado o estudo de alguns conceitos bem como de obras-chaves de certos artistas com o intuito de esclarecer escolhas e evidenciar as balizas do percurso de criação.

Nos três ciclos de trabalhos aqui descritos, vermelho, verde e cinza-corde-pele, entendo que o meu corpo, em vivências imersivas com a cor, aos poucos, borra-se com o entorno, se transforma e faz emergir poética. No cotidiano, a percepção dos movimentos corporais é muitas vezes eclipsada pela força da mecanização. Na medida em que introduzo no dia-a-dia uma tonalidade, criase uma ambiência e desvios de hábitos acontecem, ações ganham novos rumos e por meio da experimentação dos pequenos movimentos, são desencadeadas práticas e investigações.

Assim como na pesquisa, neste texto, o corpo como um todo será solicitado enquanto potencial criativo e participador do visível. Será por meio do agenciamento entre os sentidos, tátil e visual, que a abordagem conceitual será estruturada. É hipótese que este espaço intersensorial específico (tátil-visual) é constantemente ativado em meu corpo no seu embate direto com a matéria e com a visualidade nas práticas das artes visuais: pintar, desenhar, preparar misturas $^{1} . .$. Ações que envolvem fundamentalmente: o manipular e o observar.

1 Por mais que existam relações entre as diversas áreas artísticas podemos evocar referências de cada linguagem. Não no sentido de compactuar com as restrições dos campos mas de pensar que, a partir do momento em que é delimitado, torna-se possível a identificação de propriedades e detalhamentos que o caracterizam. E, as aberturas e encontros podem acontecer de maneira cuidadosa, rigorosa. 
Como estes movimentos reverberam e transformam todo o corpo? Quais qualidades de movimentos produzem?

Como consequêencia do fazer e fazer-se, coloca-se em evidência certo estado de presença vibrátil do artista plástico a ser explorada como elemento sutil das artes performativas. Não para generalizar, mas encontrar princípios a partir de vivências de meu corpo colocado em xeque neste campo artístico.

Cabe ressaltar que, quando falarmos de performance, desejamos evocar uma temporalidade que se relaciona não ao espetáculo, mas aos processos vitais que beiram a arte. Trata-se de um estudo relacionado aos fenômenos diminutos e às experimentações cotidianas.

Iniciamos esta introdução com o preto e com o branco, como convite aos pequenos movimentos, a partir daí criaremos as nuances, gradações e escalas. E, dacapo ${ }^{2}$, podemos rever este texto como campo preto sobre fundo branco e evocar seu conteúdo em imagem: dissolver o escrito em cor.

2 Dacapo é um termo da língua italiana usado nas partituras musicais para indicar a volta ao início da composição ou frase. 


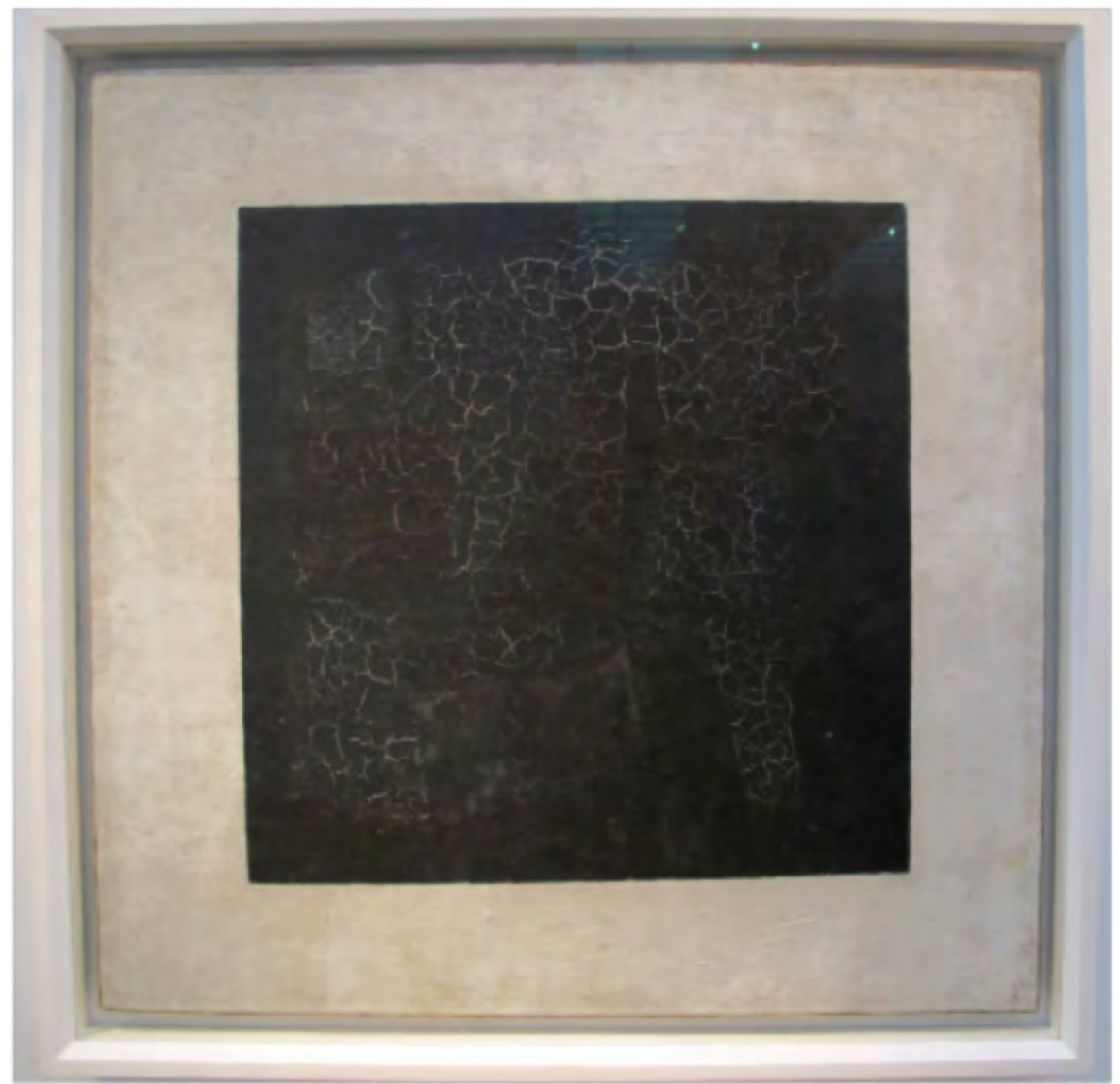

Kazimir Malevich - Quadrado Preto sobre um fundo Branco - 1915 


\section{Nuances e ciclos}

Iniciei minha carreira artística aos dezenove anos de idade com as artes circenses e aos poucos experienciei outras abordagens, modos de fazer. Passei pela dança, pelas artes cênicas, por estudos da música... Nos últimos anos, me aproximei das artes visuais de maneira intensa e compreendi este campo como base propulsora de experimentações e processos criativos.

Os trabalhos aqui apresentados são inevitavelmente respaldados por todas estas vivências e por isto os circunscrevo às artes performativas num exercício de entrelaçamento do vivido com o que está por vir, as criações. Cabe ressaltar que não se trata de uma fundamentação autobiográfica, mas de retomar algumas experiências relevantes que contribuem para uma leitura dos trabalhos e processos aqui compartilhados.

Quando decidi seguir a carreira circense, não lembrava de ter ido ao circo na infância... o que me lançou naquela direção foram as visões alegóricas que minha avó me relatara de quando assistira aos espetáculos em seus tempos de menina... O picadeiro no centro da cidade, os cortejos pelas ruas, era tudo precário, improvisado e genuíno. Aqueles relatos me sugeriam humor, romance e non-sense. Tinha o risco, também. As imagens longínquas trazidas por seu tom de voz próximo, em situações só eu e ela, eram como um segredo... E também, de olhos mais abertos e pés no chão, um pouco mais tarde, quando recebi o convite para participar de uma companhia profissional inesperadamente. Fugi com o circo.

Mas o mercado de trabalho em São Paulo era muito diferente daquelas histórias de minha avó. Alta velocidade dos eventos, as referências criativas provenientes de grupos de outros países, principalmente do Cirque du Soleil ${ }^{3}$, um interesse pelo que havia de mais virtuoso e exagerado, o hi-tech sempre obsoleto.

3 O Cirque du Soleil é uma companhia circense canadense criada nos anos 1980 e que entre os anos de 1990 e 2000 se tornou mundialmente conhecida por seus diversos espetáculos de extrema precisão técnica acrobática, bem como, pelo uso de novas tecnologias na concepção cenográfica e visual. 
As possibilidades de expressão poética em tal contexto se davam pontualmente, eram quase vislumbres, e, de fato, a primeira vez que tive espaço para elaboração de um número com mais cuidado foi quando recebi o prêmio estímulo do PAC - Programa de Ação Cultural de São Paulo, em 2008, com o projeto Circo do Miúdo ${ }^{4}$. Dalí em diante, comecei a buscar e insistir que o trabalho de arte não poderia estar atrelado à industria do espetáculo. Para mim, o estudo de práticas e conceitos é fundamental, e a temporalidade dilatada é importante no sentido de deixar que o próprio trabalho sugira seu tempo e suas formas.

Em 2009, me envolvi com o grupo Viver Dança e Cia, conduzido pelo bailarino José Maria Carvalho5 . Compartilhamos experimentações corporais e leituras diversas no Projeto de Pesquisa à Dança, apoiado pelo Fomento Munici$\mathrm{pal}^{6}$. Naquele processo, propus ao grupo uma experimentação do corpo com a cor que reverberava as experimentações com pintura que desenvolvia paralelamente em ateliê.

No final daquele ano, diante de vários questionamentos percebi que desejava o exercício do silêncio, reflexão e prática dos pequenos gestos e movimentos. O Circo Miúdo já apontara este tipo de caminho e agora, no contexto das artes visuais, as práticas corporais seriam outras, talvez mais próximas do cotidiano e distante da virtuose. Naquele momento percebi certos fazeres do artista plástico como qualidade específica e potencialmente criativa para pensarmos a performance e o corpo do artista num sentido integrado com o dia-adia.

4 O projeto Circo do Miúdo iniciou com pesquisa de campo no sertão mineiro bem como com o estudo da obra de João Guimarães Rosa. Em conversas na região de Cordisburgo, cidade natal do escritor, percebi que o circo do qual as pessoas relatavam nos anos 2000, era o mesmo descrito por Rosa, já que em épocas mais recentes os espetáculos circenses não passaram por ali. Circo do palhaço chamado Miúdo e por isto o nome do projeto. Dirigido pelo bailarino José Maria Carvalho, o resultado da pesquisa foi um número aéreo de lira, de malabarismo de contato e um pequeno documentário com depoimentos dos moradores da região mineira.

5 Dançarino, coreógrafo, professor e pesquisador da dança butoh e do método Feldenkrais. Criador e diretor do Espaço Viver Dança e Cia Trabalhou ao longo de sua trajetória com: Klauss Vianna, Denilto Gomes, Mirian Muniz, Takao Kusuo. A partir de 2001 desenvolve carreira solo, pesquisando a dança butô e o sertão mineiro através da literatura de João Guimarães Rosa.

6 Prêmio Fomento à Dança de São Paulo com o projeto de pesquisa de linguagem com: butô - O corpo em devir. 
Aparece, então, um certo descolamento pela impossibilidade de, em determinado momento experimental, não estar atrelada diretamente a coletivos. Os processos aqui apresentados, diferente da maior parte de minha trajetória, foram produzidos individualmente no ateliê. Entretanto, solicitaram pontualmente a participação de artistas. Aconteceu uma mudança das ações em grupo para procedimentos colaborativos ou reclusos no período de produção deste mestrado. Há, o desejo de compreender a minha opacidade, de visualizar fundamentos, de buscar sentido.

Relações são estabelecidas entre as práticas e os conteúdos conceituais que compõem este texto, como veremos. Porém, gostaria de evitar uma estrutura que remetesse à idéia de causa e efeito, ou de justificativa. Este primeiro capítulo trata de três ciclos de trabalhos, evidenciando por meio do texto detalhes que as imagens por si não contemplam.

Em vermelho, verde e cinza-cor-de-pele, foram estabelecidas balizas que deveriam ser seguidas ao longo de determinado tempo. A idéia foi propor vetores que indicassem o prumo de cada vivência, para que os desdobramentos encontrassem fluxo e os desvios fossem perceptíveis. E para que certas práticas participassem propositivamente da rotina diária, gerando pulsos e ciclos. Os trabalhos emergiram a partir destas proposições que em si podem ser compreendidas enquanto obra. Ao ter a possibilidade de reuni-los neste trabalho, e tecer reflexões a respeito, pude visualizar, certa poética. 

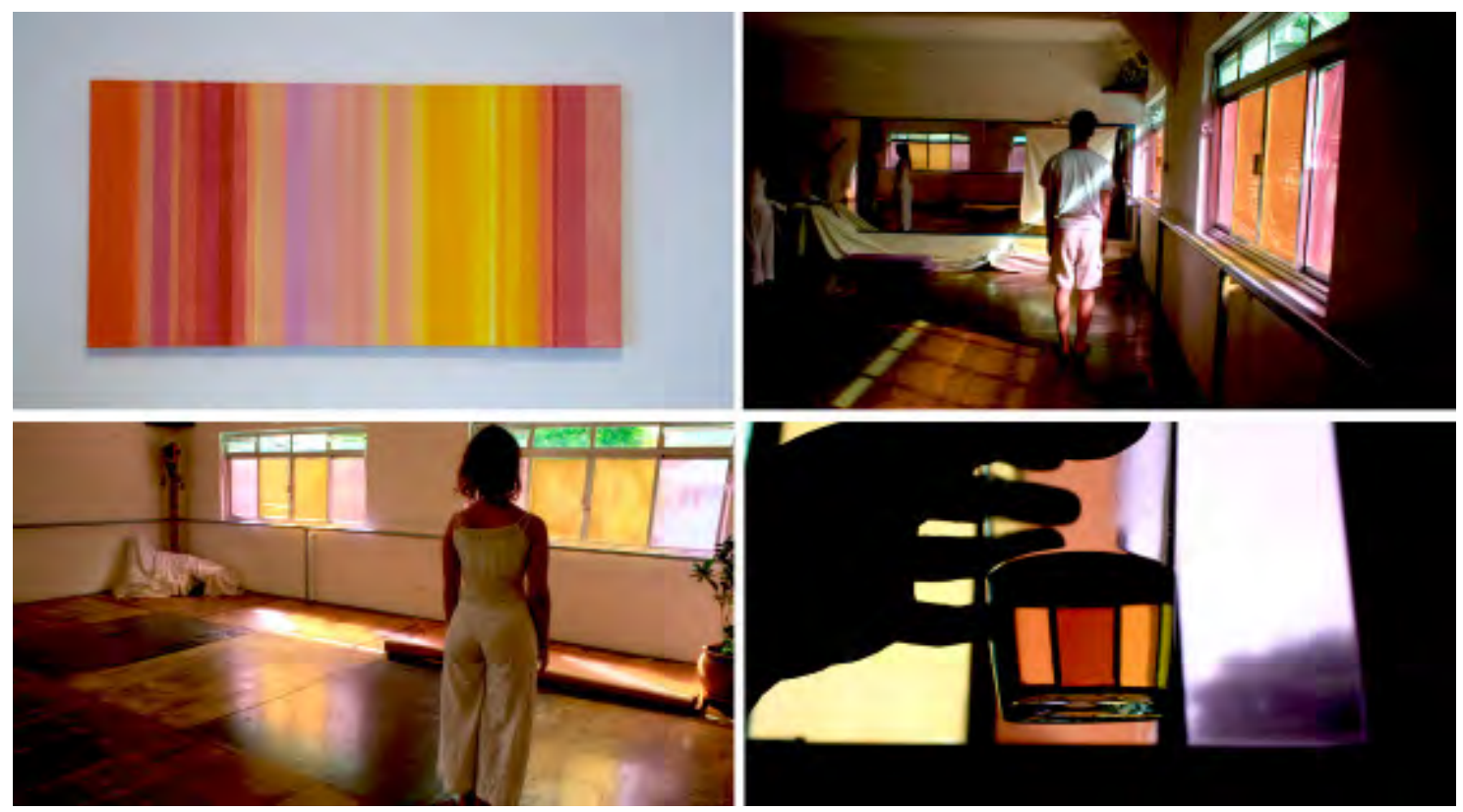

Arrebol - 2009

Experimentação cromática corporal junto ao Viver Dança e Cia a partir dos tons do céu na cidade ao cair da tarde. Nesta experimentação as janelas da sala de pesquisa foram cobertas com tons do pôr-do-sol. Mesmas tonalidades pesquisadas nas pinturas em ateliê 
ciclo vermelho 


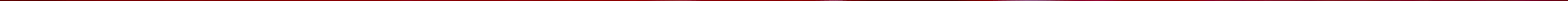




\section{Balizas do ciclo vermelho:}

- Baliza 1: criar um ambiente cromático (cobrir o coreto central da Praça dos Mártires no centro da cidade de Fortaleza com tecido, placas e luzes da praça de vermelho).

- Baliza 2: usar roupas e maquiagens em tons de vermelho.

- Baliza 3: produção pictórica em vermelho.

- Baliza 4: estar receptiva ao público e gerar interações diversas - danças, desenhos, conversas...

- Baliza 5: estar atenta para o significado que o vermelho sugeriria em tal contexto.

- Baliza 6: duração de uma semana. 


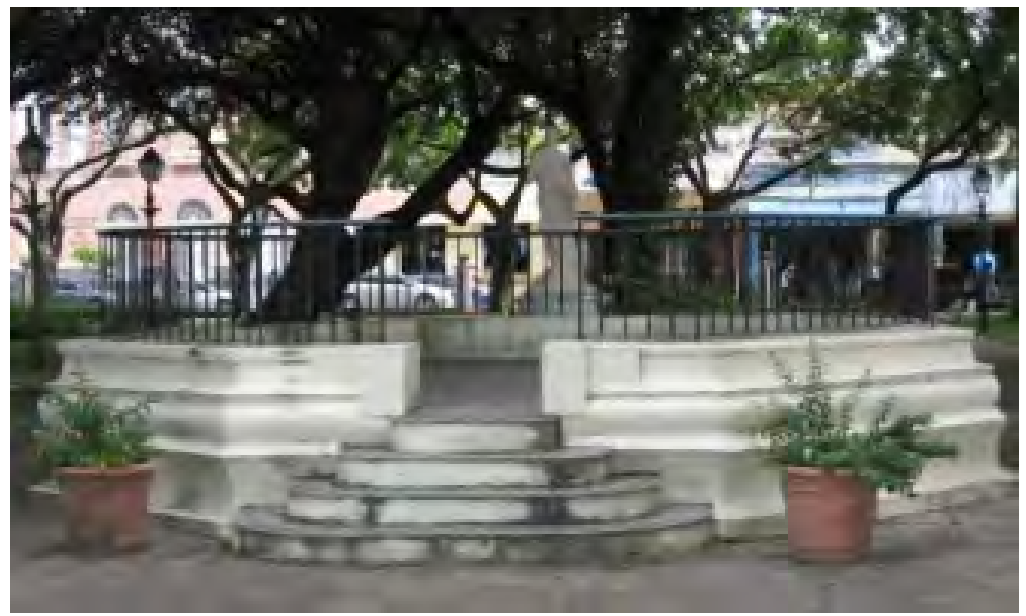

Coreto da praça dos Mártires, Fortaleza, antes da intervenção. 


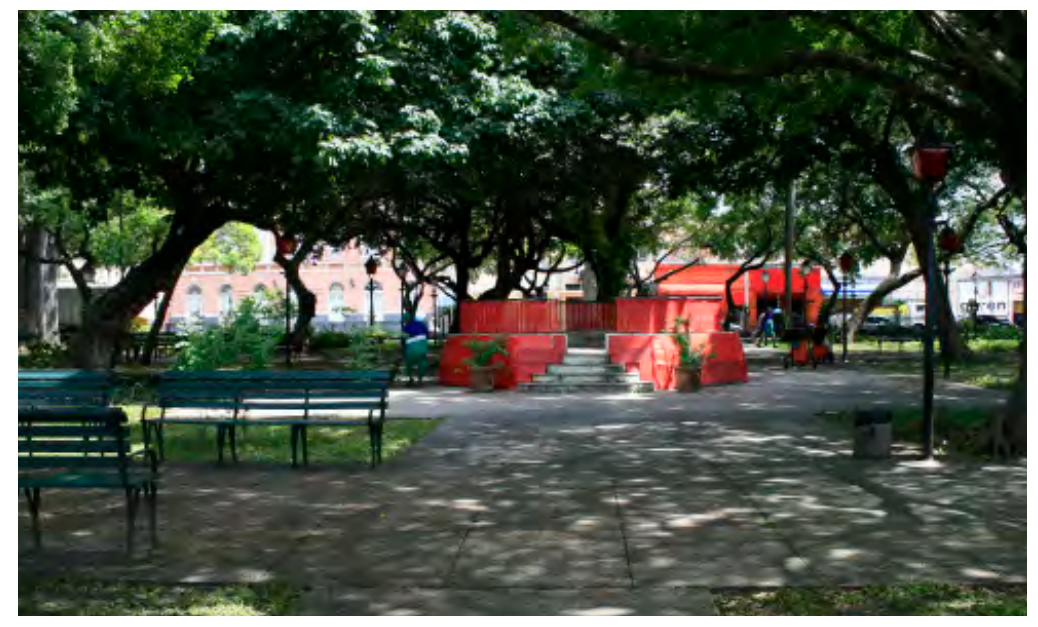

baliza 1: ambientação do coreto da praça de vermelho, 2009. 


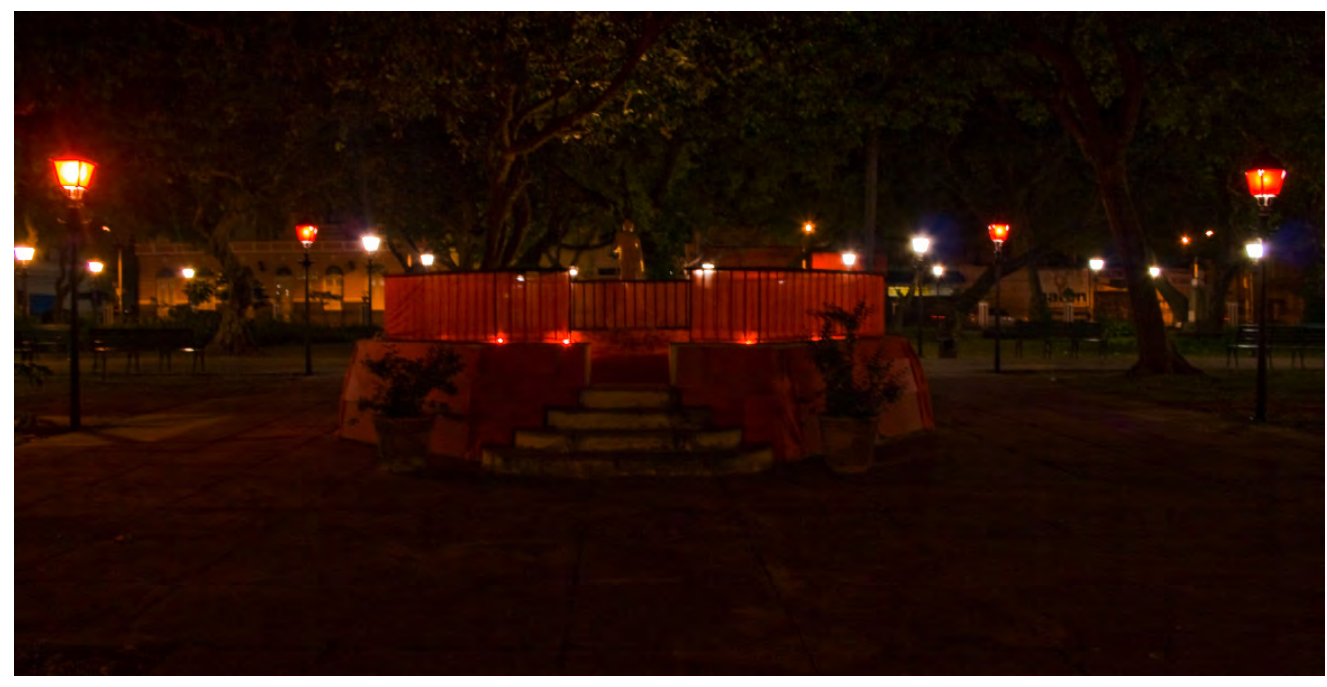

Coreto com intervenção cromática durante a noite. 


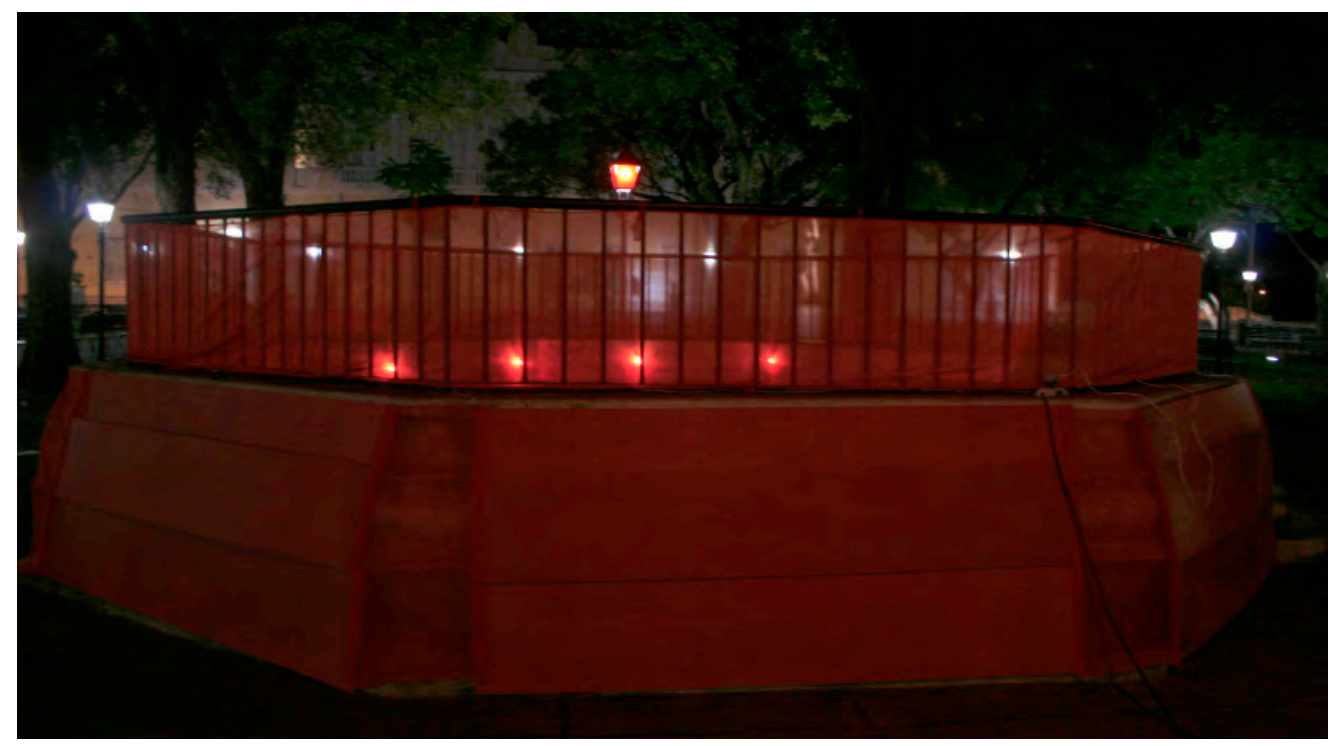


Realizado no Salão de Abril em Fortaleza, 2009, o trabalho Convergência e Dispersão a partir do Vermelho ${ }^{7}$ teve como proposta inicial ocupar o coreto da praça principal do centro histórico da cidade com elementos vermelhos e fazer daquele espaço, ao longo de uma semana, um ateliê a céu aberto.

O coreto foi coberto com tecido e placas de madeira vermelhos, bem como a iluminação da praça recebeu gelatinas da mesma tonalidade para que durante a noite o ambiente cromático se amplificasse. As ações que compunham a montagem e desmontagem da instalação também eram em si entendidas como performativas. Havia uma atenção para o estado corporal vivenciado e como este era percebido pelo público.

Ali, costurei uma roupa vermelha para mim, bem como produzi maquiagem com tons vermelhos nos dias após a montagem. Experimentações com dança, pintura e música aconteceram sempre tendo o vermelho como motivo. Os passantes participavam em pulsos: convergiam, entravam no coreto, conversavam e dispersavam, seguiam seus caminhos. Este movimento se repetia ao longo dos dias, de acordo com o fluxo natural da praça: desejo e curiosidade dos pedestres de saber o que se passava no coreto transformado.

7 Este trabalho teve como referência em sua concepção as obras Ateliê Vermelho (1911) do pintor francês Henri Matisse (1869-1954) e Desvio para o vermelho (1967) do artista brasileiro Cildo Meireles (1948). 


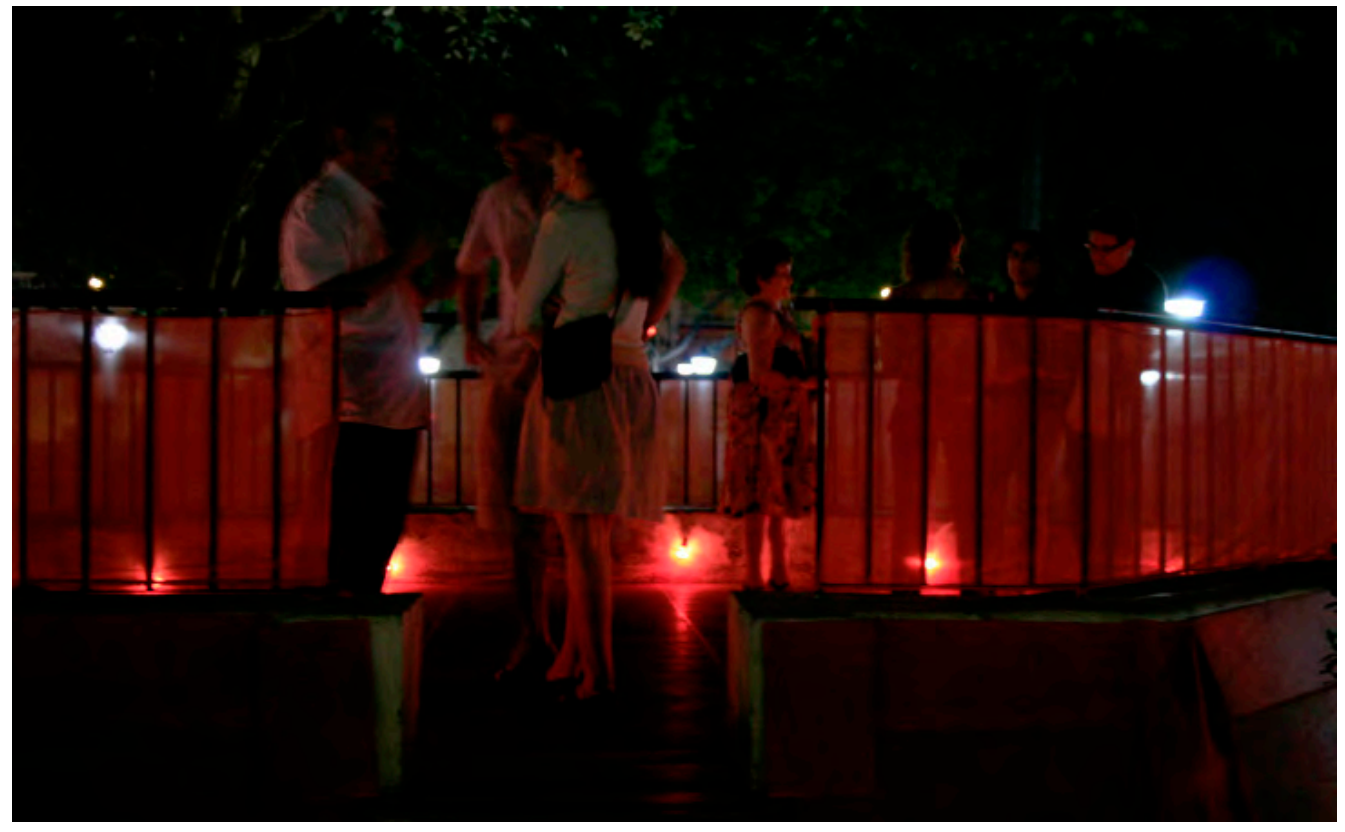


Uma das balizas do trabalho era estar atenta ao significado do vermelho em determinado contexto desconhecido para mim que vivo em São Paulo, e quais as reverberações naquele momento sócio cultural de tal instalação e performance. No centro de Fortaleza, em 2009, o ambiente e luzes vermelhas ecoaram o que o entorno circunstancialmente oferecia: a praça era ponto de prostituição, a popular, "casa da luz vermelha" no caso, a céu aberto.

Ao longo do dia, homens chegavam na praça e sentavam nos bancos. Depois de pouco tempo, as prostitutas sentavam a seu lado, conversavam. Por vezes, não seguiam para o programa. Nestes casos, depois de mais um tempo, outra mulher chegava. Se o programa fosse confirmado, logo saiam dali em direção aos pequenos hotéis do entorno.

Num dos dias em que estava realizando o trabalho, sentei num banco e, ao lado, sentou-se um senhor. Depois de certo tempo, ele me chamou e falou para eu me aproximar. Fiquei no meu lugar. Um pouco de longe, com tom enfático, perguntou se eu fazia programa. Gostava de branquinhas. Falou que pagaria $\mathrm{R} \$ 30,00$. 

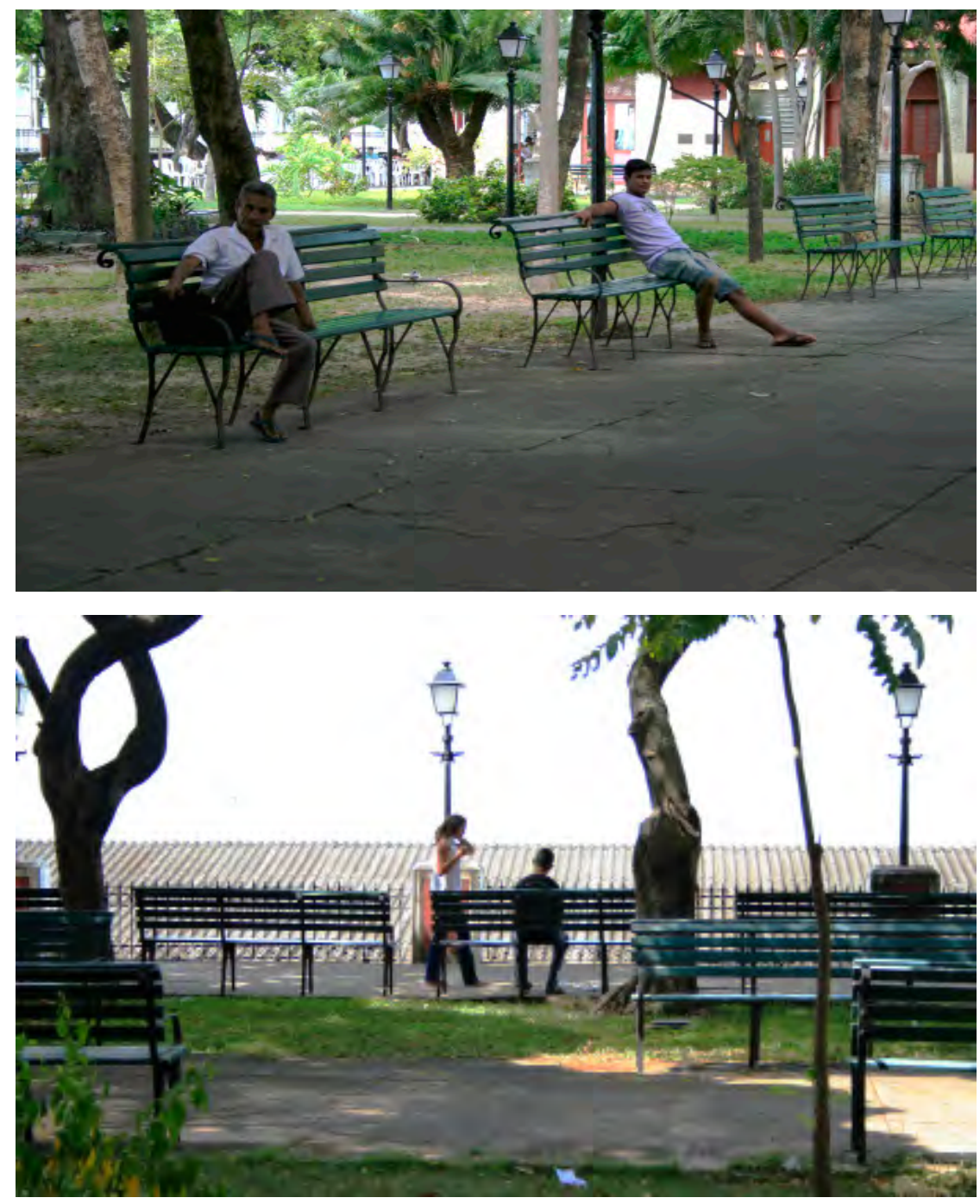

Baliza 5: estar atento para o significado que o vermelho sugeriria em tal contexto. Abordagem das prostitutas da região. 
Descobri que por ali algumas prostitutas faziam programa por até $\mathrm{R} \$$ 7,00, preço da pedra de crack. Pela manhã, mais de uma vez, encontrei mulheres com pouca roupa totalmente esparramadas no chão. A praça, de arquitetura com influências francesas do séculos XIX, impunha certo glamour europeu à circunstância e, à noite, era fechada para que o trânsito de prostitutas e travestis não ocorresse ali dentro.

O fechamento da praça, de acordo com o policial que acompanhou a realização do trabalho ao longo da semana (já que ali era um lugar perigoso de acordo com ele), era recente. Preservava-se assim um ponto turístico frágil no centro da cidade. No último dia de conversa com o policial, contando sua história, disse com certa tranqüilidade que participara de situações de tortura. Torturou presos na época da ditadura.

O vermelho e seu campo de emanações: aberto, maduro, alerta. 


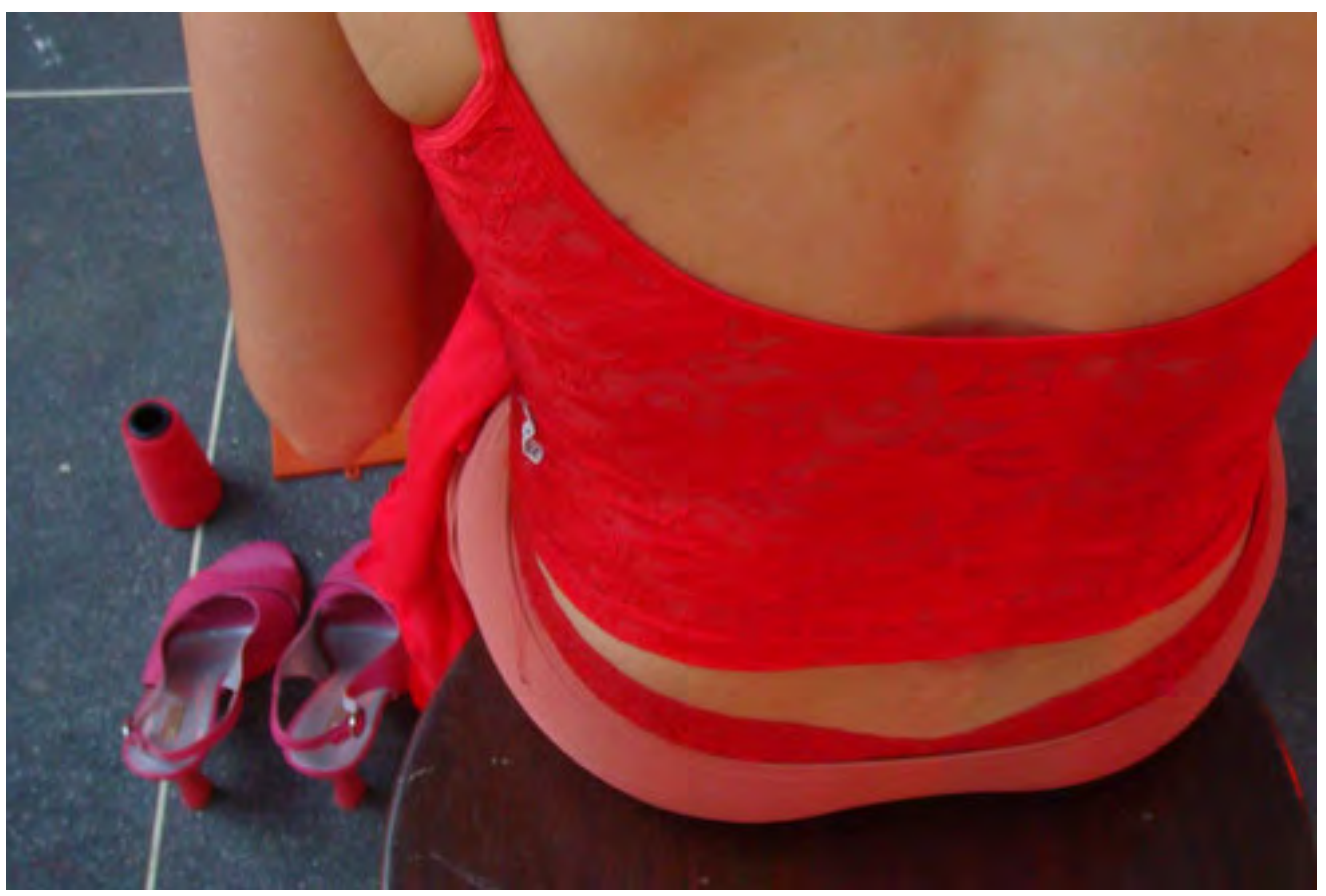


ciclo verde 


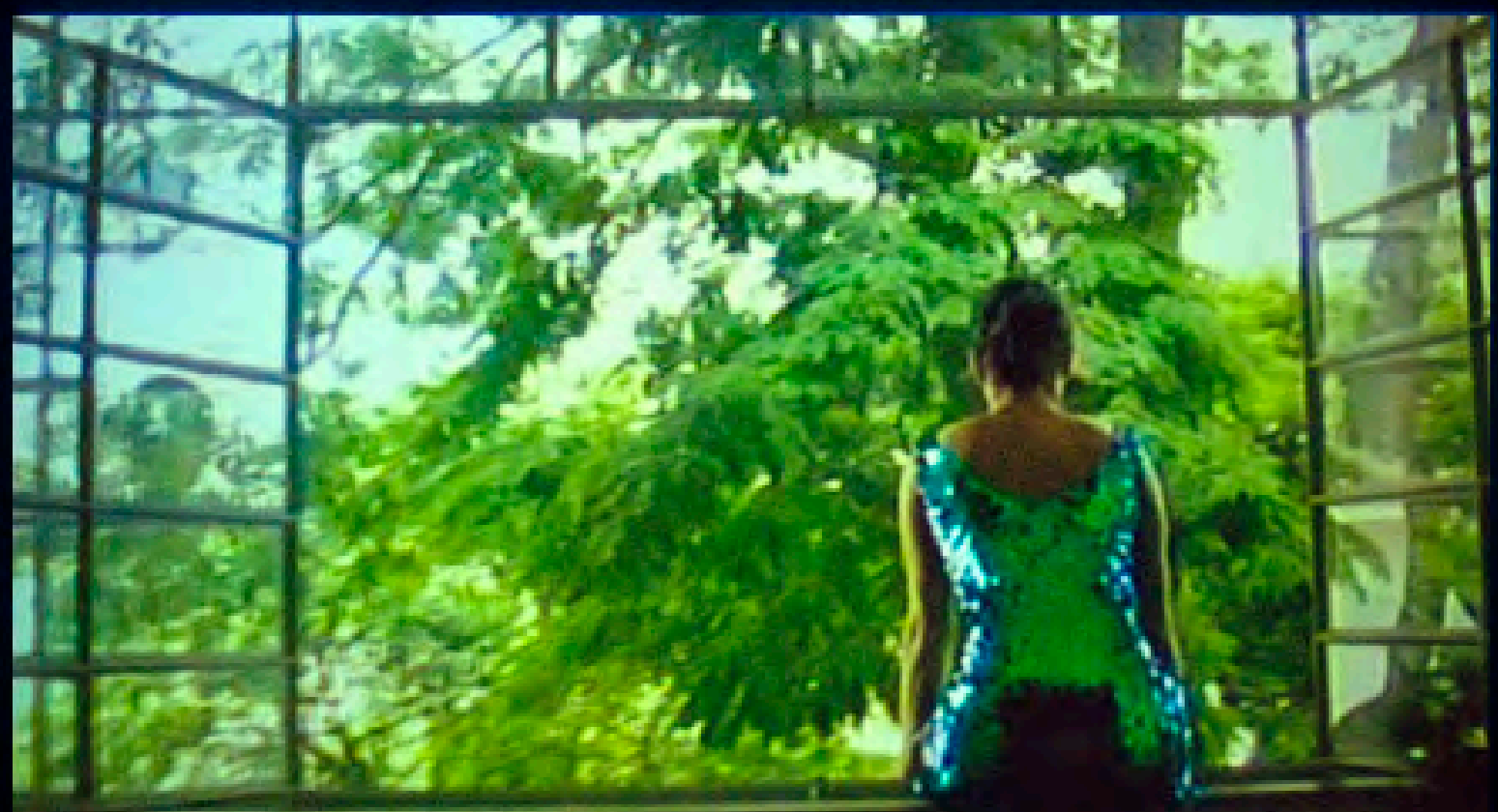




\section{Balizas do ciclo verde:}

- Baliza 1: pintar paredes da minha casa de verde.

- Baliza 2: tingir roupas e elementos da casa de verde, usar roupas verdes no cotidiano.

- Baliza 3: ingestão de alimentos verdes.

- Baliza 4: anotação num caderno de desenhos dos sonhos significativos deste período, sempre em verde.

- Baliza 5: usar verde na produção pictórica.

- Baliza 6: duração 7 meses. 
Balizas 2: utilizar elementos verdes no cotidiano.

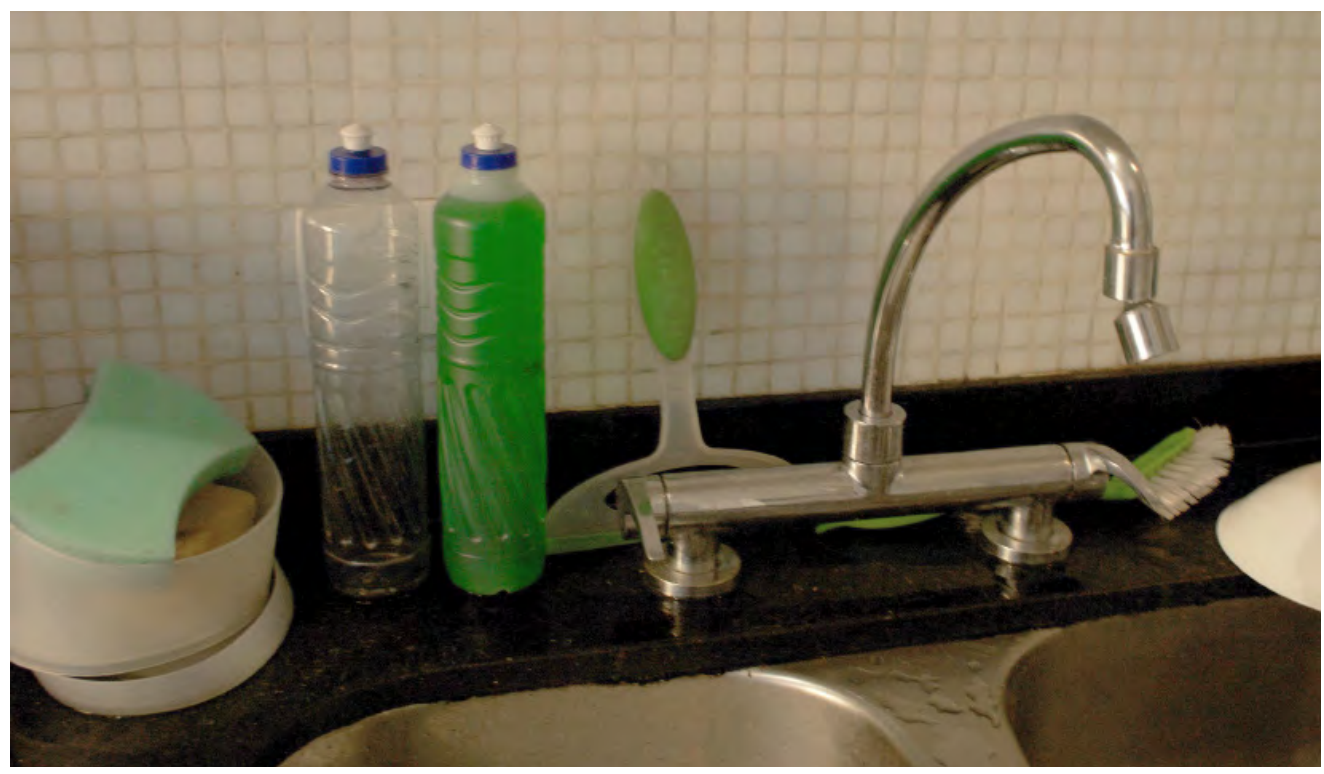



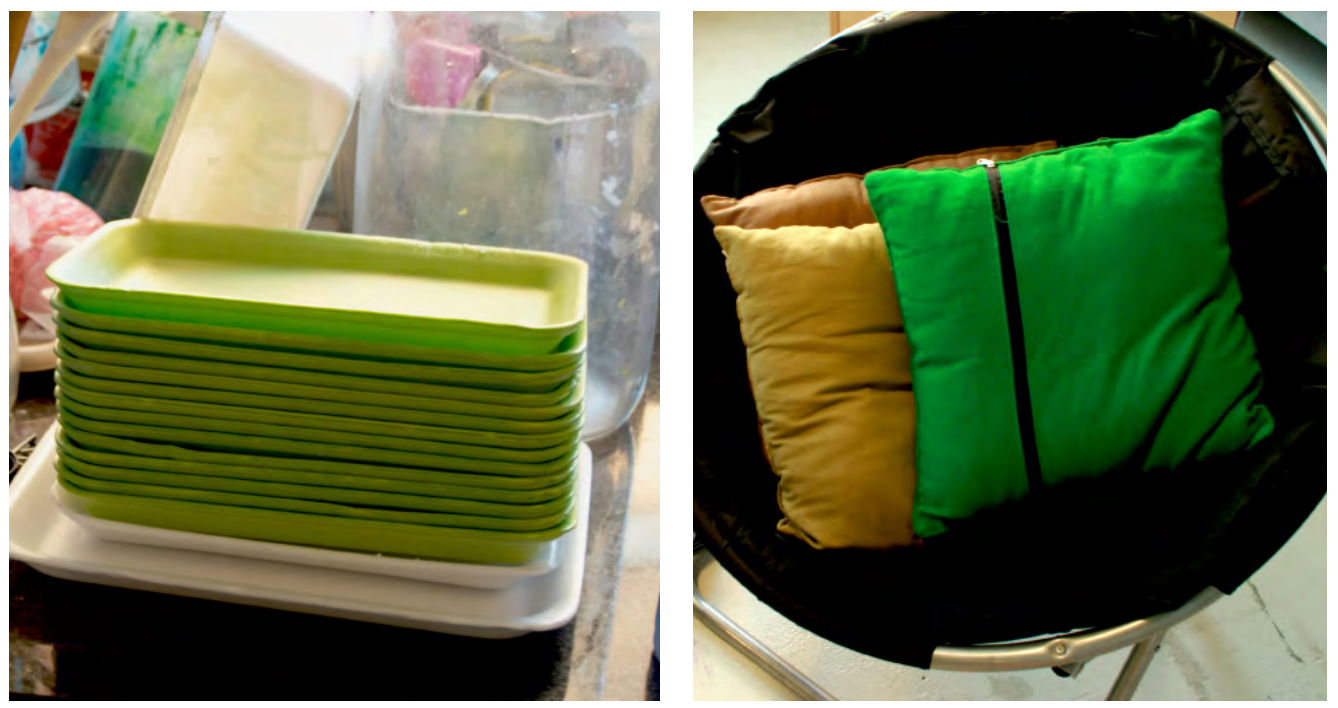
A escolha do verde como cor a ser vivenciada no processo do mestrado fez-se a partir do momento em que iniciei o ano de 2010 participando de dois trabalhos de performance: no Pará e na Serra da Capivara no Piaui ${ }^{8}$. Por todos os lados, apesar da qualidade diversa de cada uma das circunstâncias, vivenciei o verde.

Depois, já em São Paulo, decidi que para este ciclo fossem levantados procedimentos que deveriam ser praticados e inseridos de alguma forma no cotidiano num período mais longo do que o ciclo vermelho. Nesta experimentação, que duraria sete meses, decidi pintar as paredes de minha casa de verde, usar verde em elementos do uso diário como o sabão para lavar louças, roupas de cama e de banho...

Percebi que algumas práticas pictóricas poderiam estar num lugar entre as práticas da pintura (como as que me aproximei na graduação em Artes Plásticas) e aquelas do cotidiano de uma casa, como por exemplo o tingimento das roupas de verde que envolvia cozinhar, lavar e secar a roupa.

8 O trabalho realizado na Serra da Capivara, no Piauí, aconteceu dentro do parque ecológico onde encontraram-se importantes pinturas rupestres brasileiras. O projeto Entrextremos, idealizado pela artista Carolina Pinzan junto ao Coletivo Urubus, foi uma vivência imersiva de criação em performance com princípios provenientes das artes cênicas. No Pará, Alter do Chão, tratava-se do projeto Circo em Alter, concebido por Marina Guzzo, que consiste num trabalho de aproximação das crianças locais das artes circenses por meio de processos criativos diversos. 


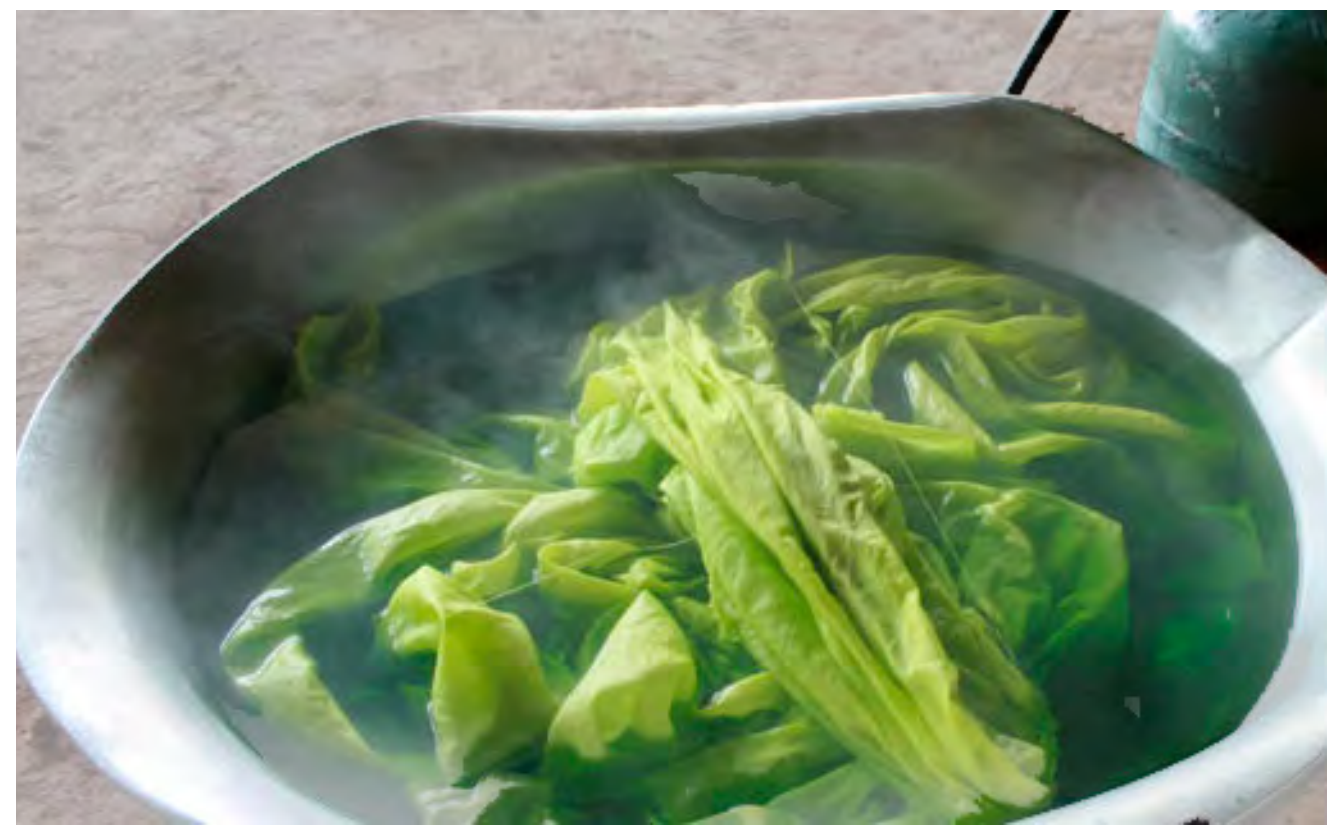

baliza 2: tingir roupas e elementos da casa de verde, usar roupas verdes no cotidiano. 


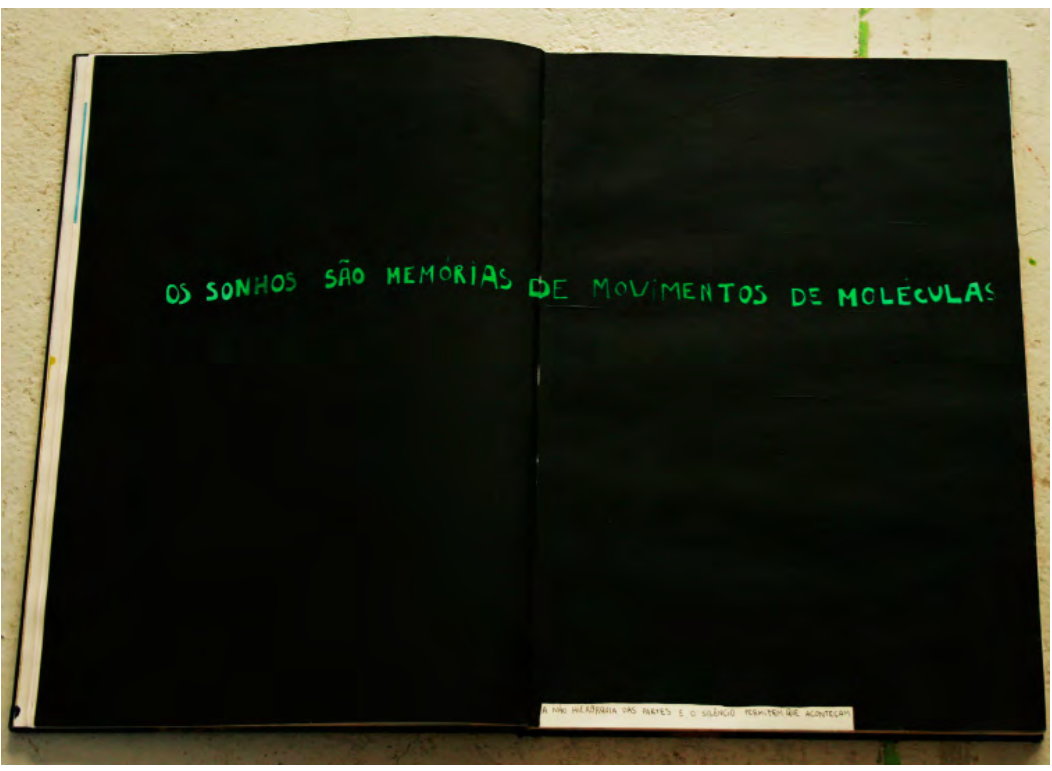

Caderno de desenho de sonhos. 
Outra baliza do trabalho era a anotação em desenhos, dos sonhos marcantes que eu tivesse no período dos sete meses, sempre utilizando tons de verde. Com o tempo, percebi que se tratava de um exercício complexo e, por vezes, desgastante de estudo do imaginário. Este material, gerou desdobramentos, outros trabalhos foram feitos. 
Baliza 4:

anotação num caderno de desenhos dos sonhos significativos deste período, em verde.

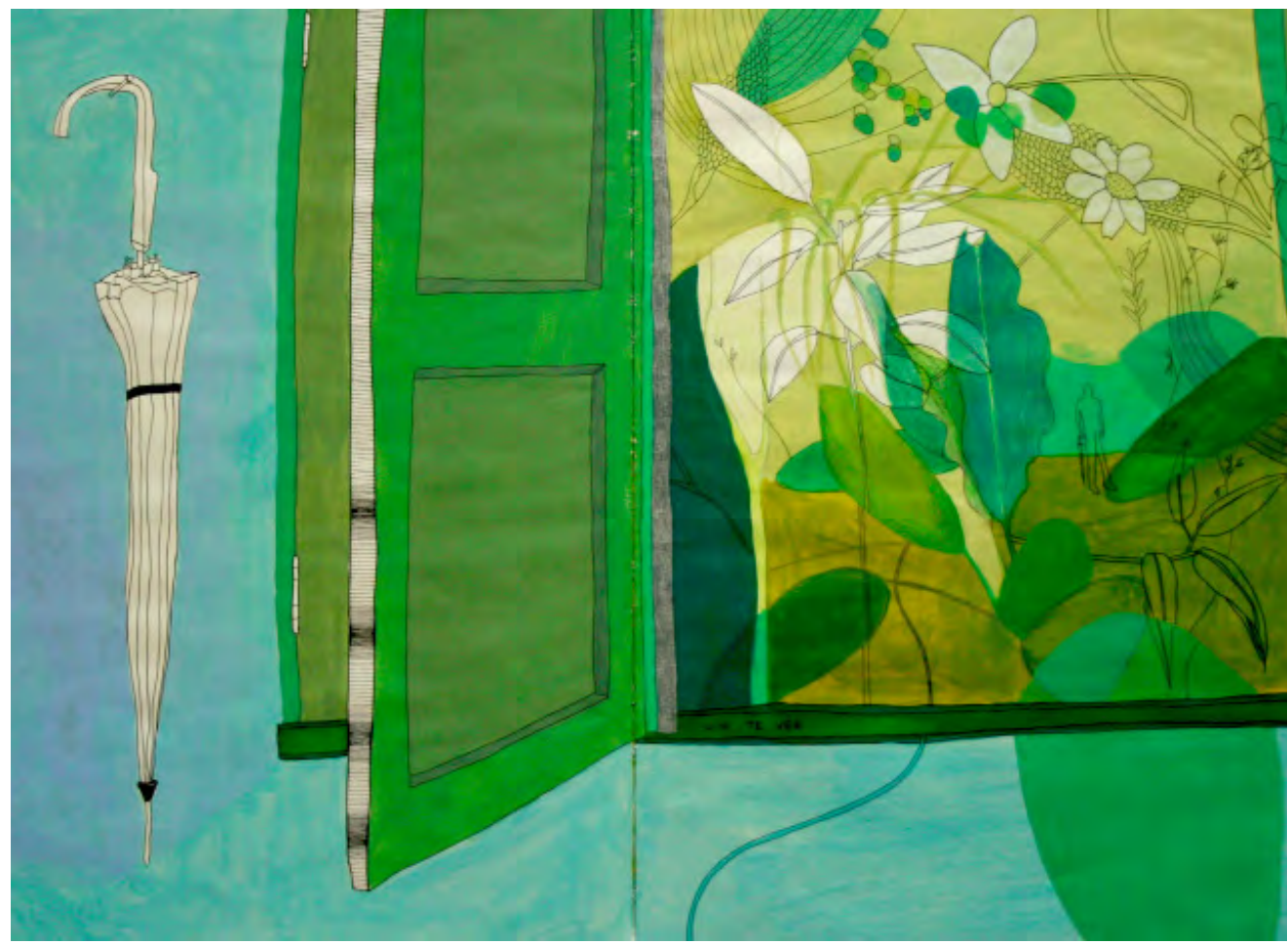




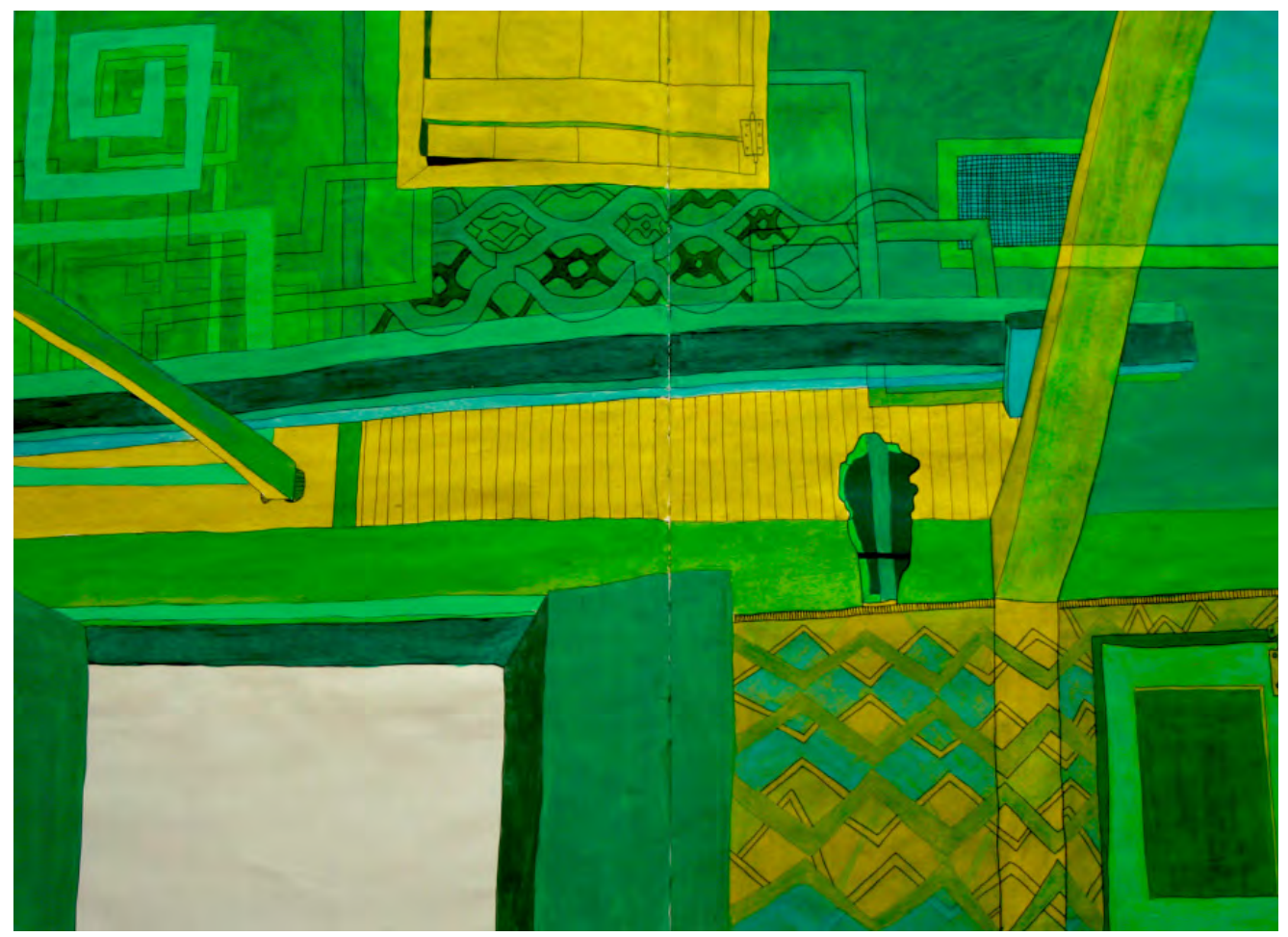


Este processo foi acompanhado de mudanças significativas em minha vida. Depois de trabalhar 12 anos com as artes aéreas do circo, descobri um problema em minha coluna e os médicos sugeriram que eu me afastasse desta prática. Caminhando para uma pesquisa que desejava desvendar as qualidades do corpo do artista plástico, o acaso desestabilizou as referências experimentadas pelo meu corpo anteriormente e abriu novos caminhos. Transformação da percepção, do cotidiano, da identidade e possibilidade de aprofundamento vivencial da pesquisa.

Como desdobramento deste ciclo, foram ainda realizados dois trabalhos: o curta-metragem, ilusão no 6 - o peixe insolúvel (ver DVD em Anexo) e uma pintura, tinta acrílica sobre tela9

O curta foi criado a partir da síntese de imagens do caderno (baliza 4) e do registro de uma performance aérea que ocorreu na Virada Cultural (início de 2010). Os elementos da narrativa ficcional do filme - a persona ${ }^{10}$ Solange, o sabonete, o peixe, a janela - organizaram-se de maneira a referenciarem-se uns aos outros em espelhamentos. O caminhar, as escamas do peixe, a água, o verde são elementos que, de maneira tátil-visual, apresentam-se e são constantemente retomados ao longo do curta.

9 Em 2011 estes dois trabalhos foram instalados no Paço das Artes (São Paulo) como parte da exposição Espaços da Cor realizada pelo Grupo de Pesquisas Cromáticas da ECA/USP.

10 Renato Cohen (1956-2003), pesquisador e artista brasileiro, sugere que na performance existe a persona como um contraponto à idéia de personagem do teatro. A persona seria como uma das qualidades ou identidades inerente ao performer e não uma personagem que ele interpreta, que incorpora de fora para dentro. 


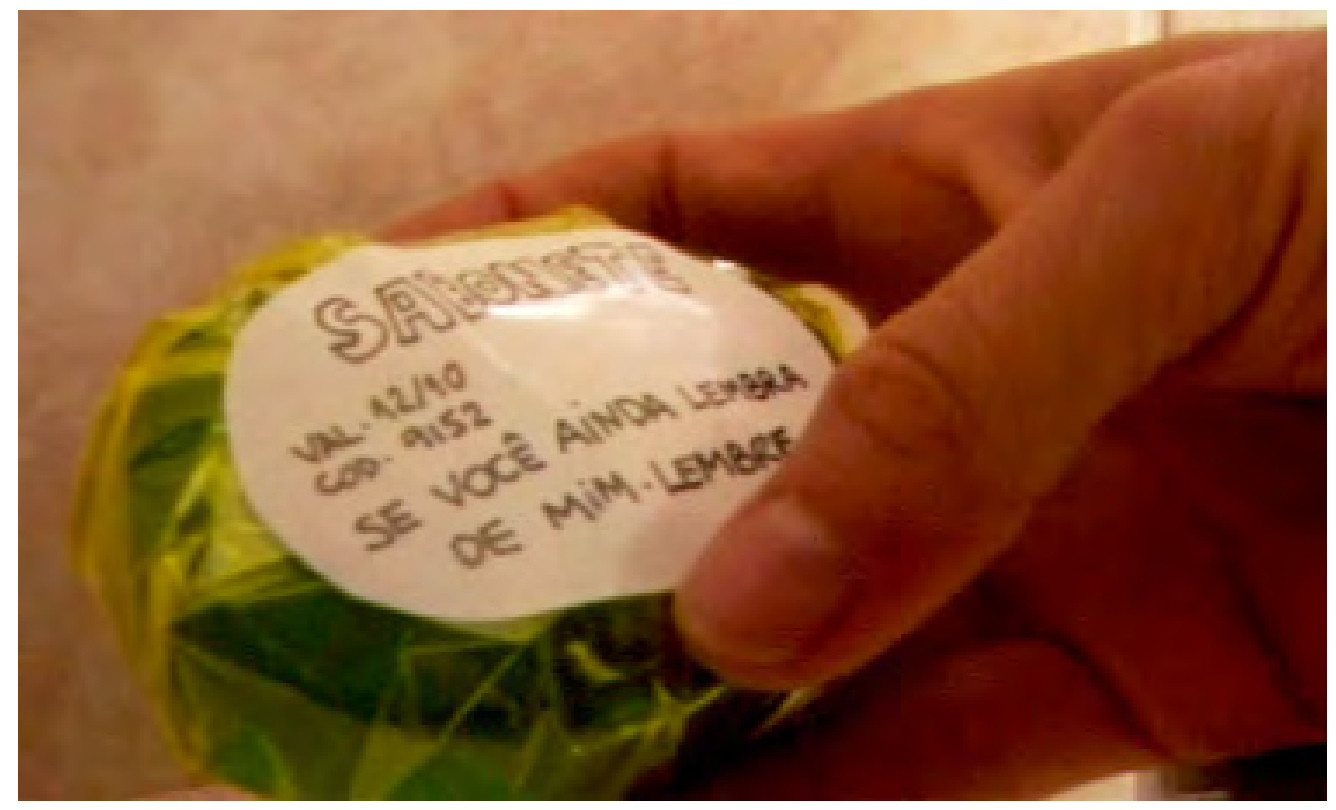

Frame do curta ilusão $n^{\circ} 6$ - o peixe insolúvel. 


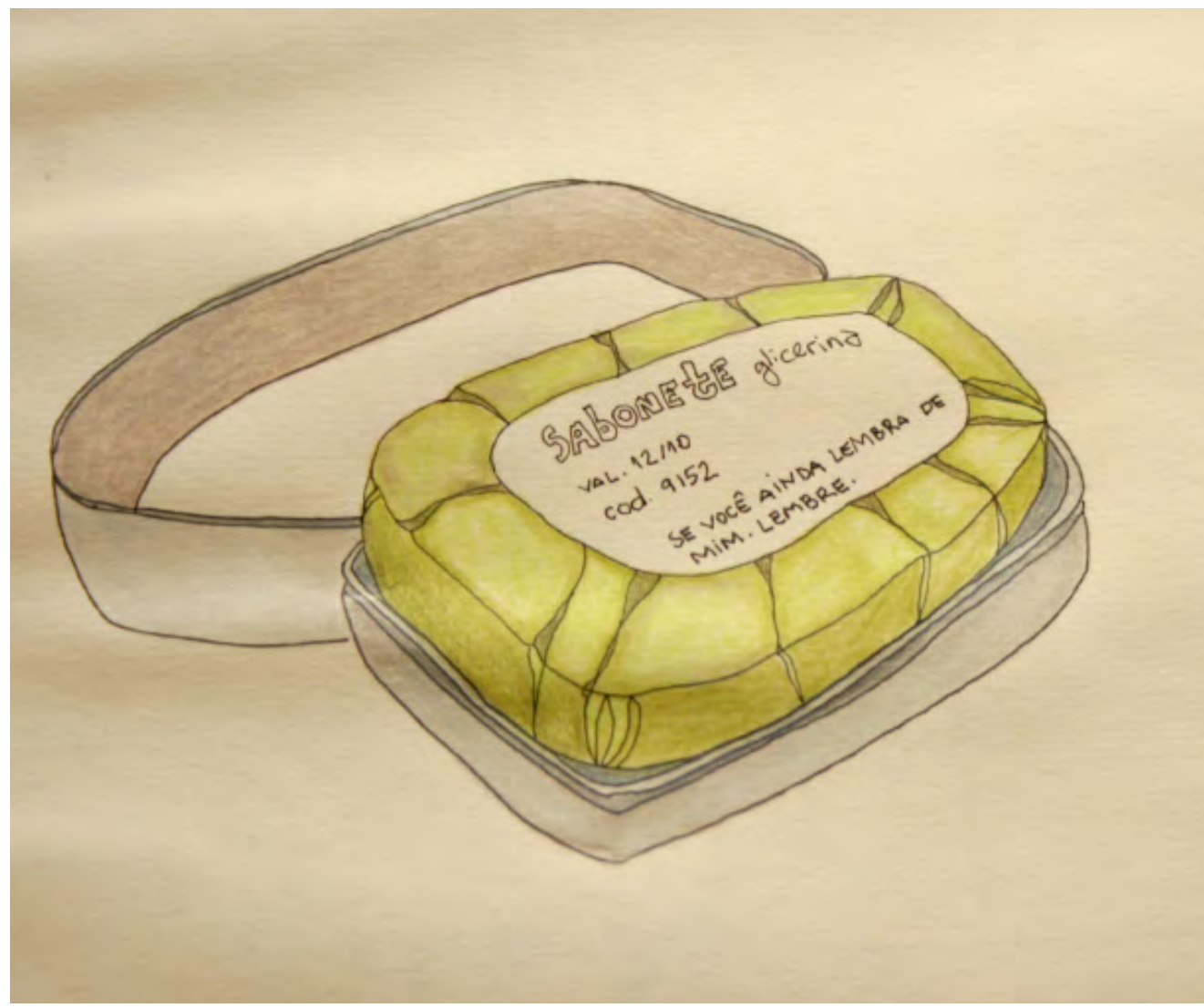

Imagem do caderno de sonhos. 
Os desenhos do caderno de sonhos organizados de determinada maneira formaram uma espécie de story board non sense. Cada imagem tratava de um sonho em dias diferentes de minha vida e, para construir com este material uma narrativa, procurei possíveis relações entre as imagens: espelhamento interno e ciclos.

Imagens vem e voltam como num estado de vertigem e suspensão: o andar nas ruas, as escamas do peixe e do vestido, as situações de limite, a janela, o caminhar no ar, a beira da calçada, o folhear do caderno (que no caso é o próprio caderno dos desenhos dos sonhos)...

O curta registra a passagem de um envolvimento dos movimentos ligados ao espetáculo para movimentos do cotidiano e suas implicações. 
Persona Solange:

imagem da Virada Cultural 2010, nesta página, e imagem do caderno de sonhos, na seguinte.

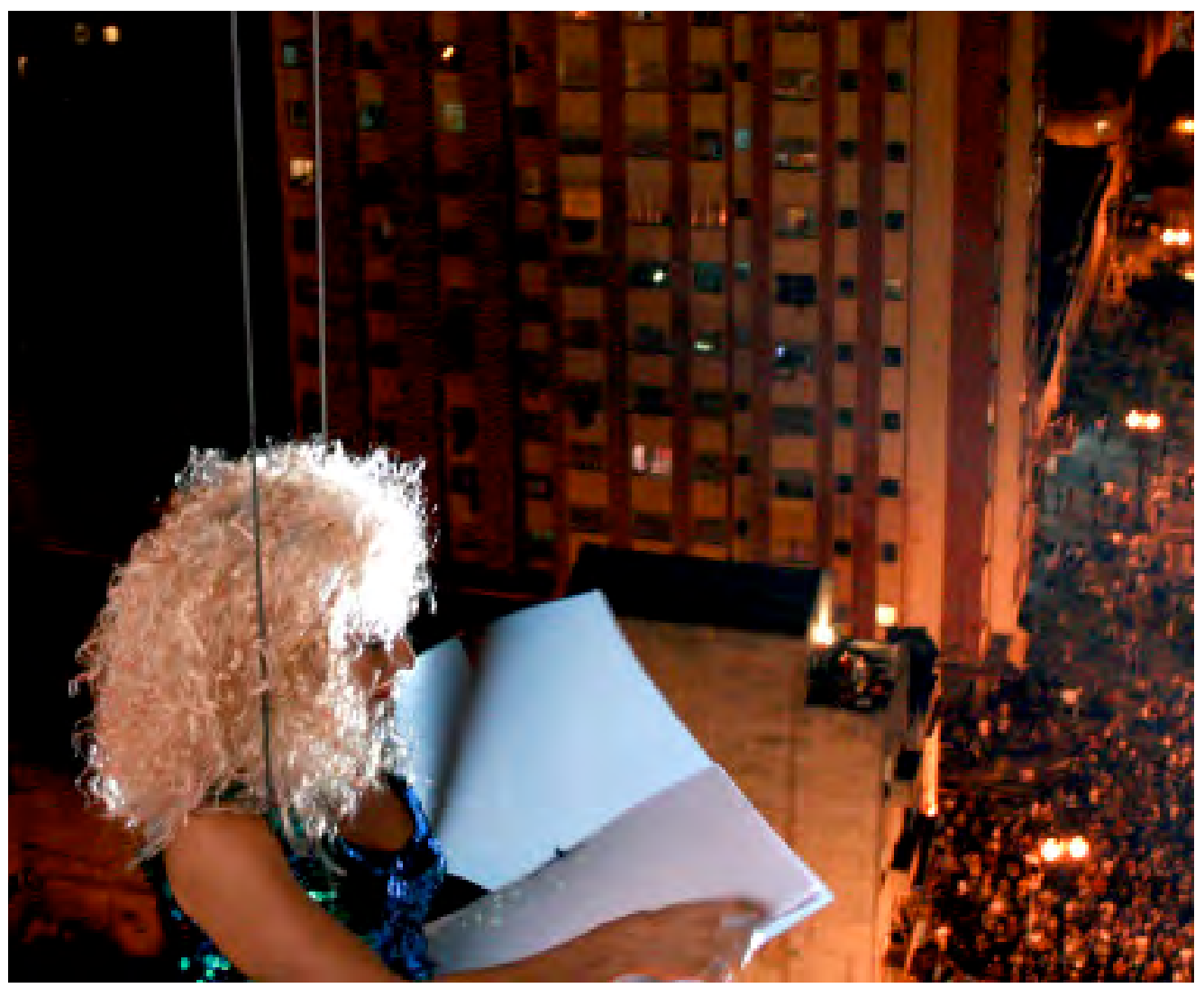




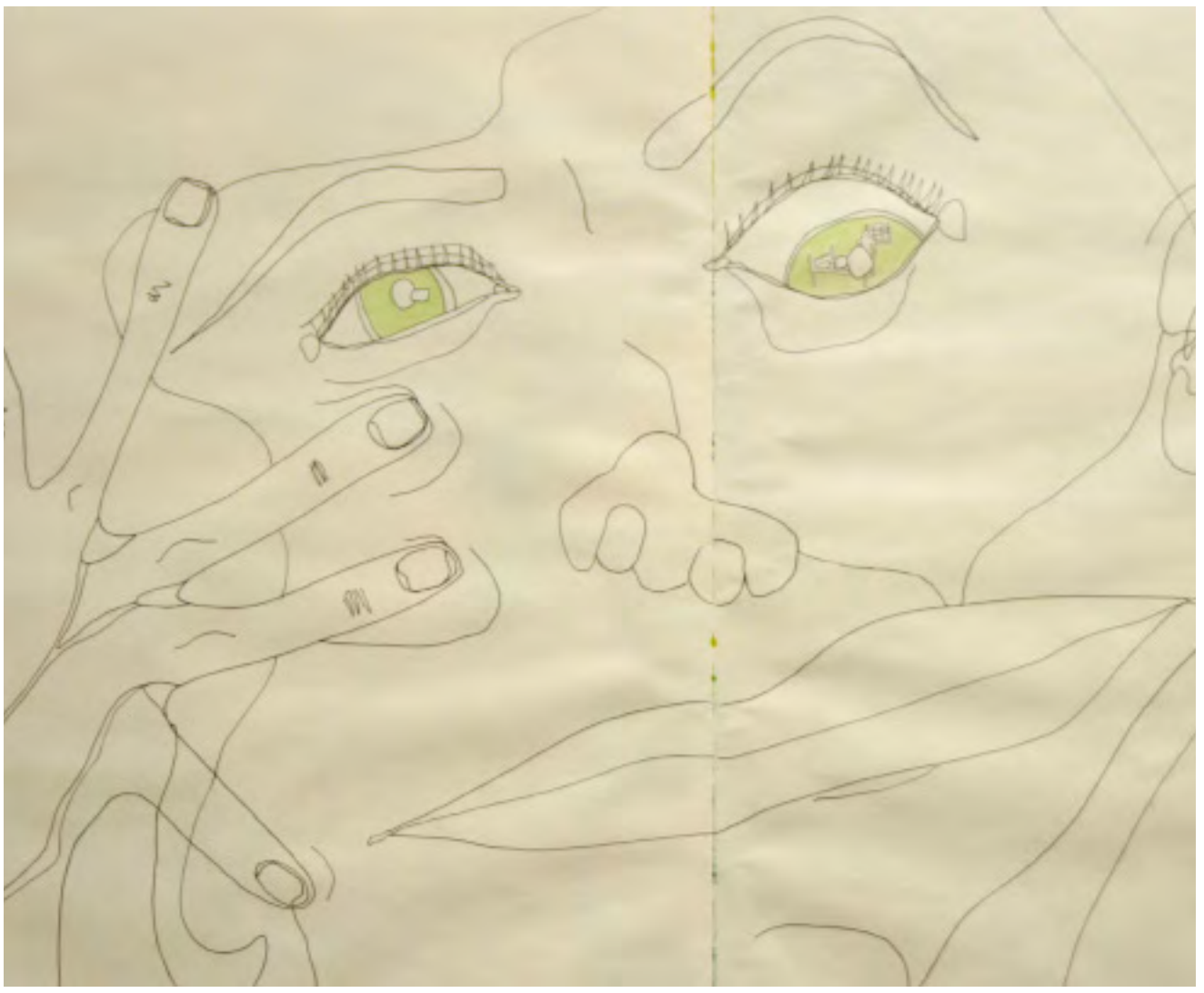


O outro trabalho relevante deste ciclo foi a pintura em tinta acrílica sobre tela sem título $(140 \mathrm{~cm} \times 160 \mathrm{~cm})$. Esta foi criada num processo lento que durou os sete meses e ativou certa sensibilização do olhar, do tato e da luminosidade da cor escolhida. Revelou a qualidade da sobreposição de imagens: a vegetação pintada em camadas criou intersecções e transparências.

O processo de mistura dos pigmentos, movimento circular do pincel dentro do pote, foi repetição cotidiana significativa. Cada cor produzida antes de ser aplicada na tela. Temporalidade que me conduzia, me transformava. Amarelos, azuis, brancos, pretos, muitos verdes...

O verde e seu campo de emanações: interiorizado, onírico e ficcional. 


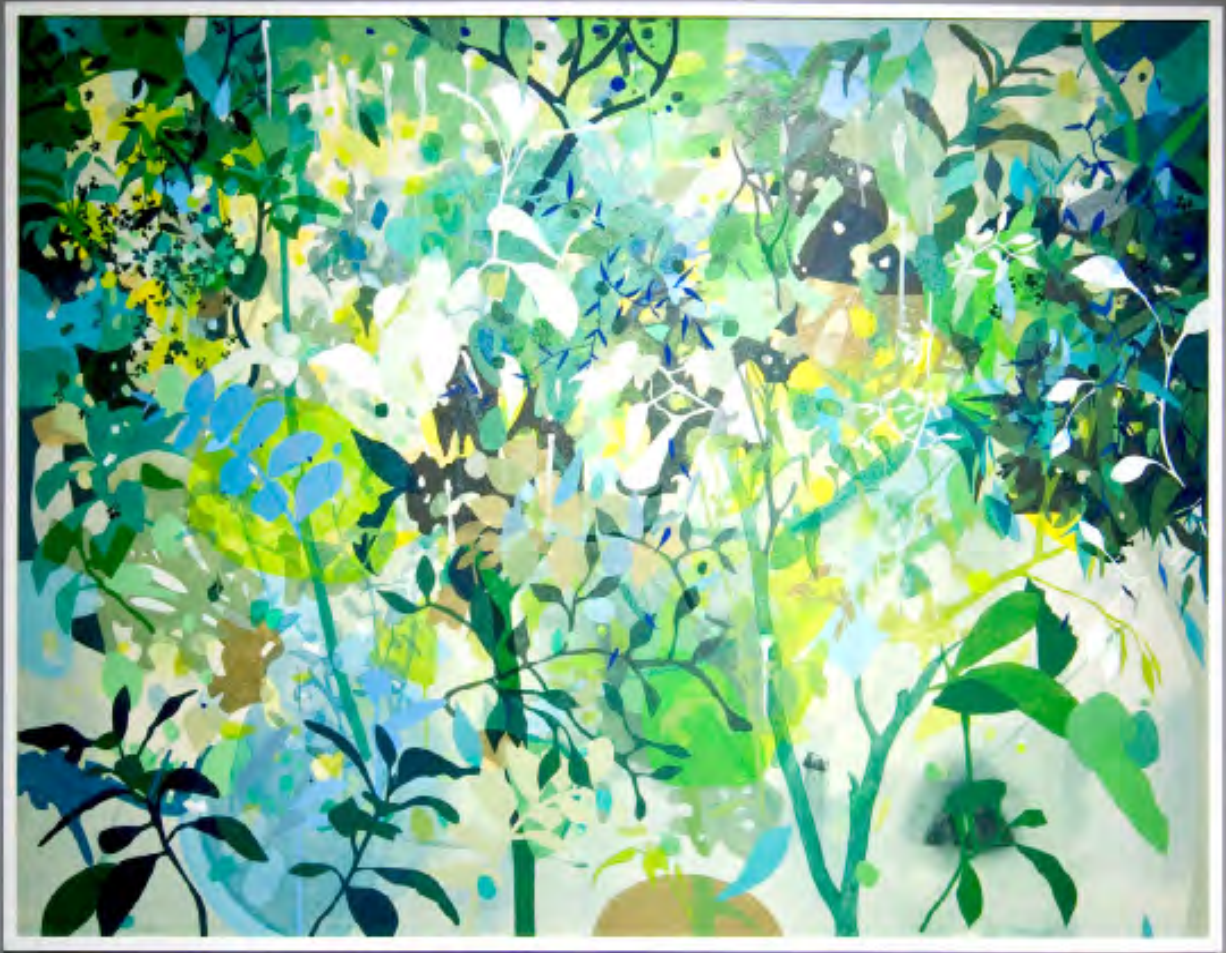

sem título - pintura tinta acrílica sobre tela - 2010 
cinza-cor-de-pele 


\section{Balizas do ciclo cinza-cor-de-pele:}

- Baliza 1: ambientar minha casa com a escala cinza-cor-de-pele.

- Baliza 2: tingir um pedaço de tecido a cada mudança de lua dentro da escala cinza-cor-de-pele.

- Baliza 3: usar o cinza-cor-de-pele na produção pictórica.

- Baliza 4: usar o cinza-cor-de-pele em roupas no cotidiano.

- Baliza 5: realizar e registrar em vídeo todos os dias, durante o ciclo, um gesto. Fosse ele ativado por uma sensação interna ou pela observação de um gesto de um pedestre nas ruas.

- Baliza 6: duração 9 meses. 

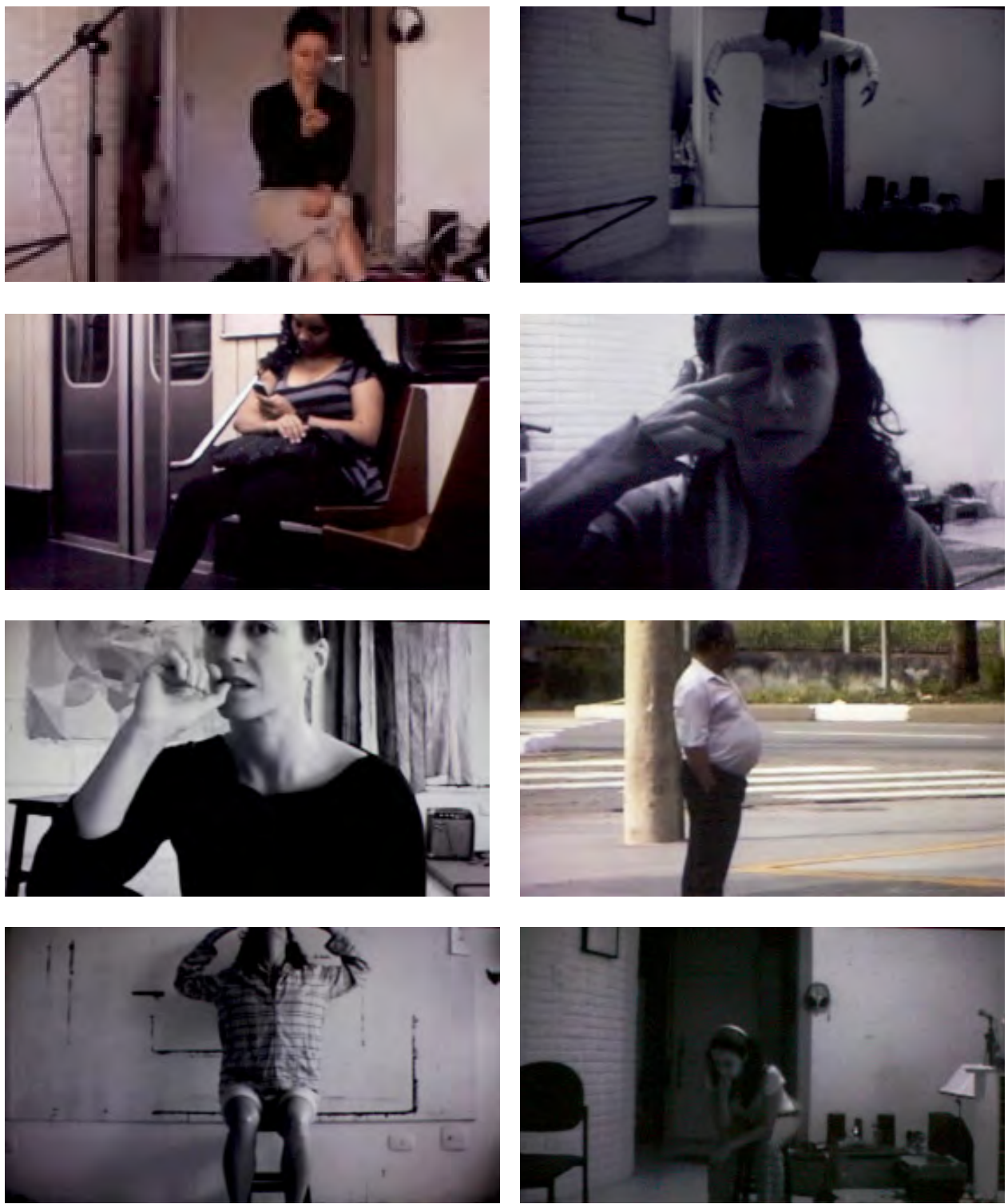

Cartografia: baliza 5 - realizar e registrar todos os dias, durante 9 meses, um gesto. Fosse ele ativado por uma sensação interna ou pela observação de um gesto de um pedestre na rua (ver DVD no anexo). 
Neste terceiro ciclo, que também ocorreu no período do mestrado, foram escolhidas as cores cinza e de pele. A imagem inicial é de quando, ao sair à rua, as partículas da cidade (fuligem e tantos outros micro-materiais) entram em contato com meu corpo. São as cores que me compõem, as dos outros corpos e também as da cidade ao se trocarem microscopicamente. Os tons e meio tons foram muitos e matizados. Onde o dentro e o fora se encontram?

Neste estudo, a atenção se deteve na passagem do meu corpo para os outros e vice-versa. Poética do tocar e ser tocado. Manter permeabilidade ou saber dosá-la, foram em si componentes deste ciclo.

No exercício do encontro com a cidade e com elementos do cotidiano, certas balizas que propunham pulsos foram fundamentais. Havia de fato a referência ao corpo feminino: nove meses e as mudanças da lua. A velocidade que a cidade muitas vezes impõe ao comportamento deveria ser interrompida por outras cadências. Que cidade habito? Quais temporalidades?

Em casa, me dei conta, por meio das ações sugeridas pela baliza 5, que a relação com a cidade permanece nos menores movimentos que me compõem: tensão, inquietude, movimentos rígidos... sensações que os gestos sugeriram ao serem revistos. Os registros editados num filme (DVD anexo) foi intitulado Cartografia. 

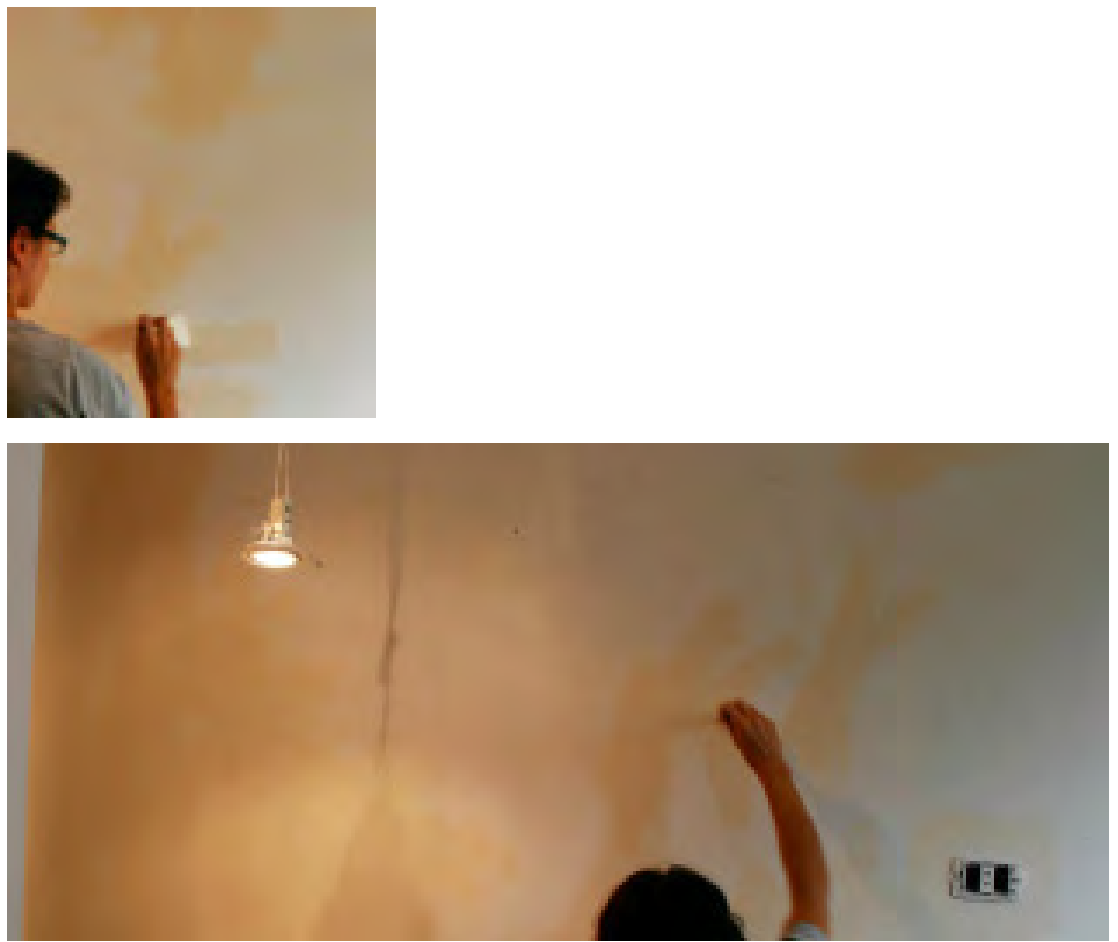

baliza 1: pintura das paredes da casa - 2011 

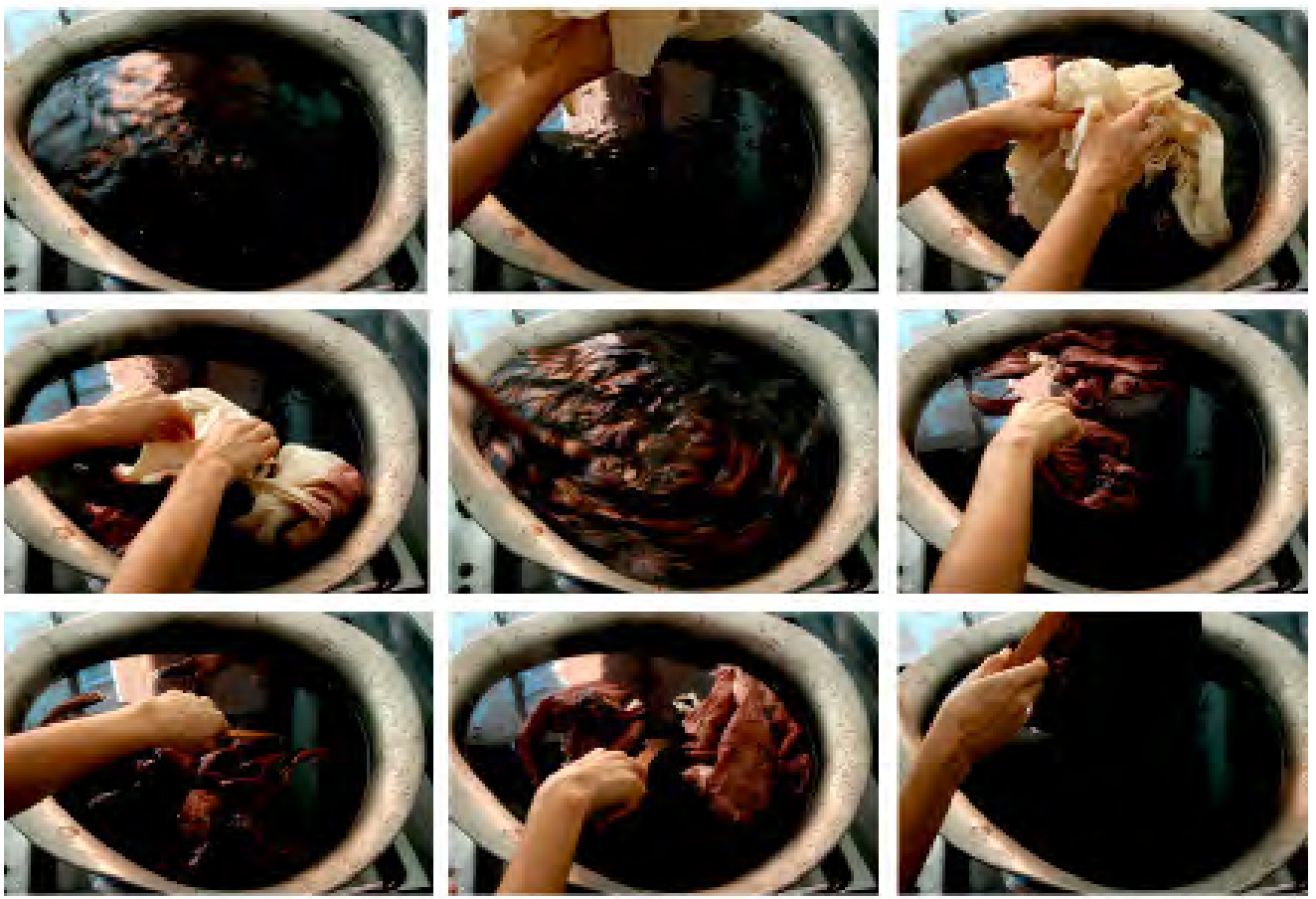

baliza 2: tingir um pedaço de tecido a cada mudança de lua - 2011/2012 


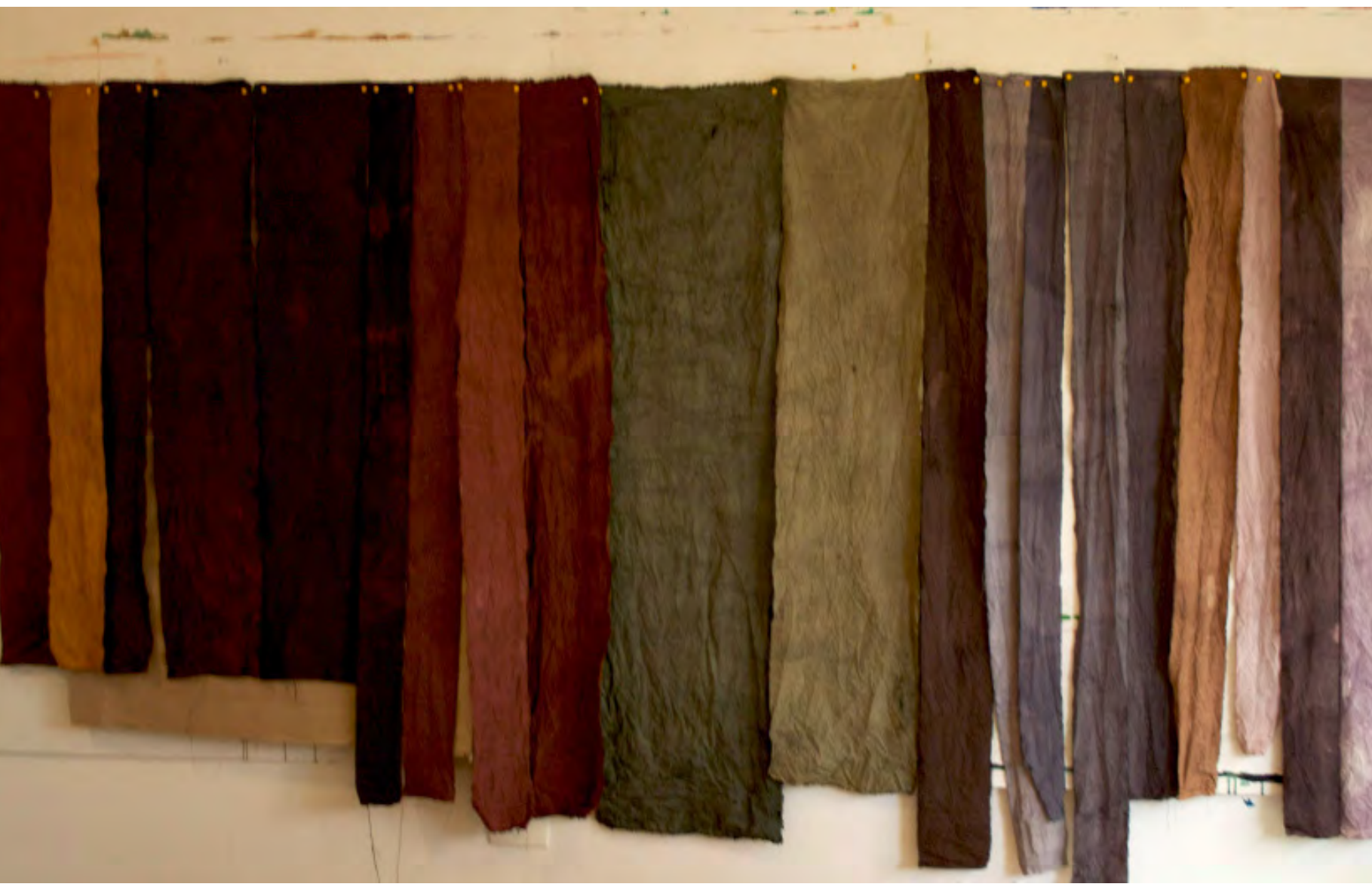




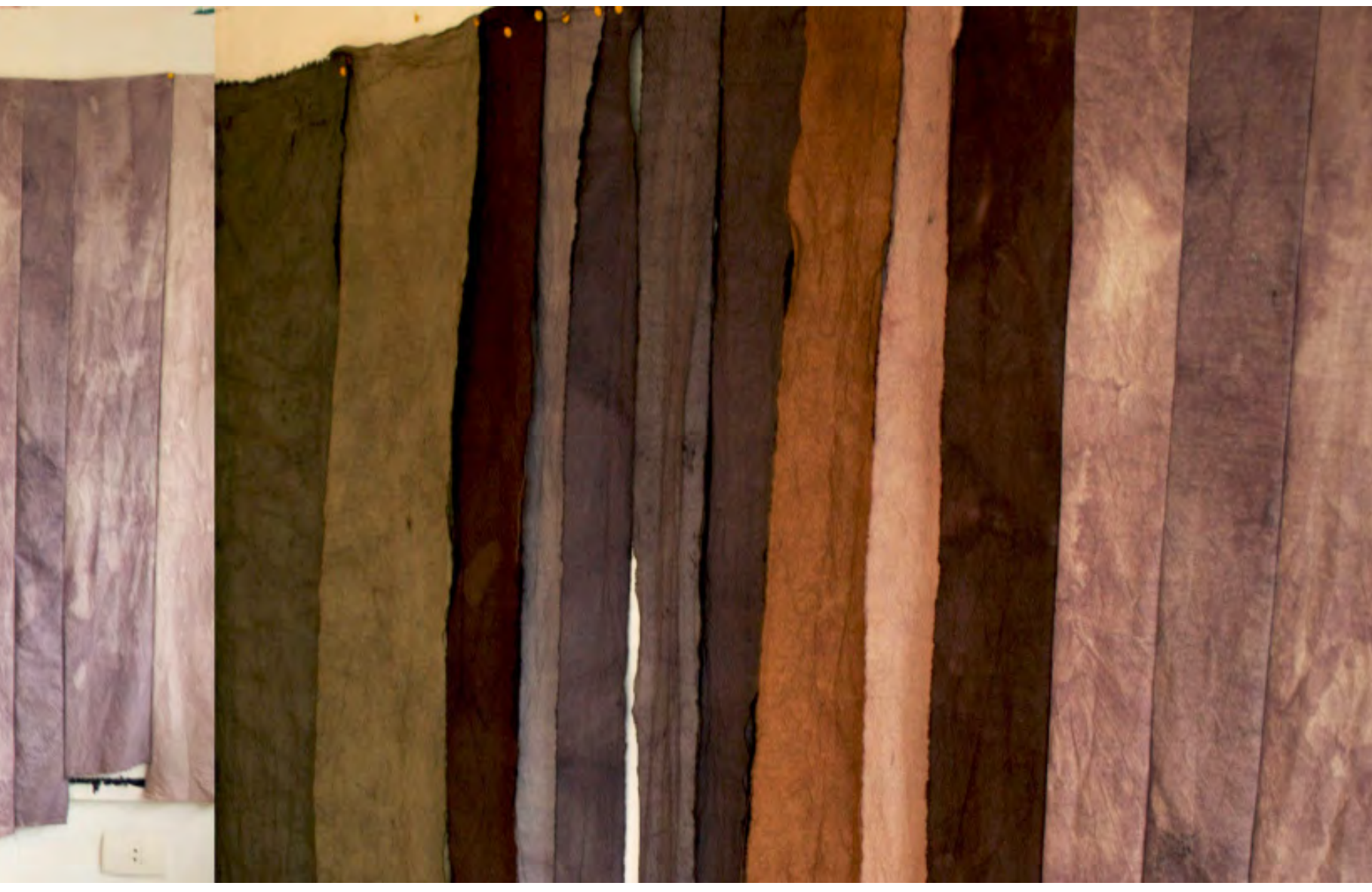

Parte dos tecidos pintados (baliza 2), organizados em ordem cronológica - 2011 e 2012 


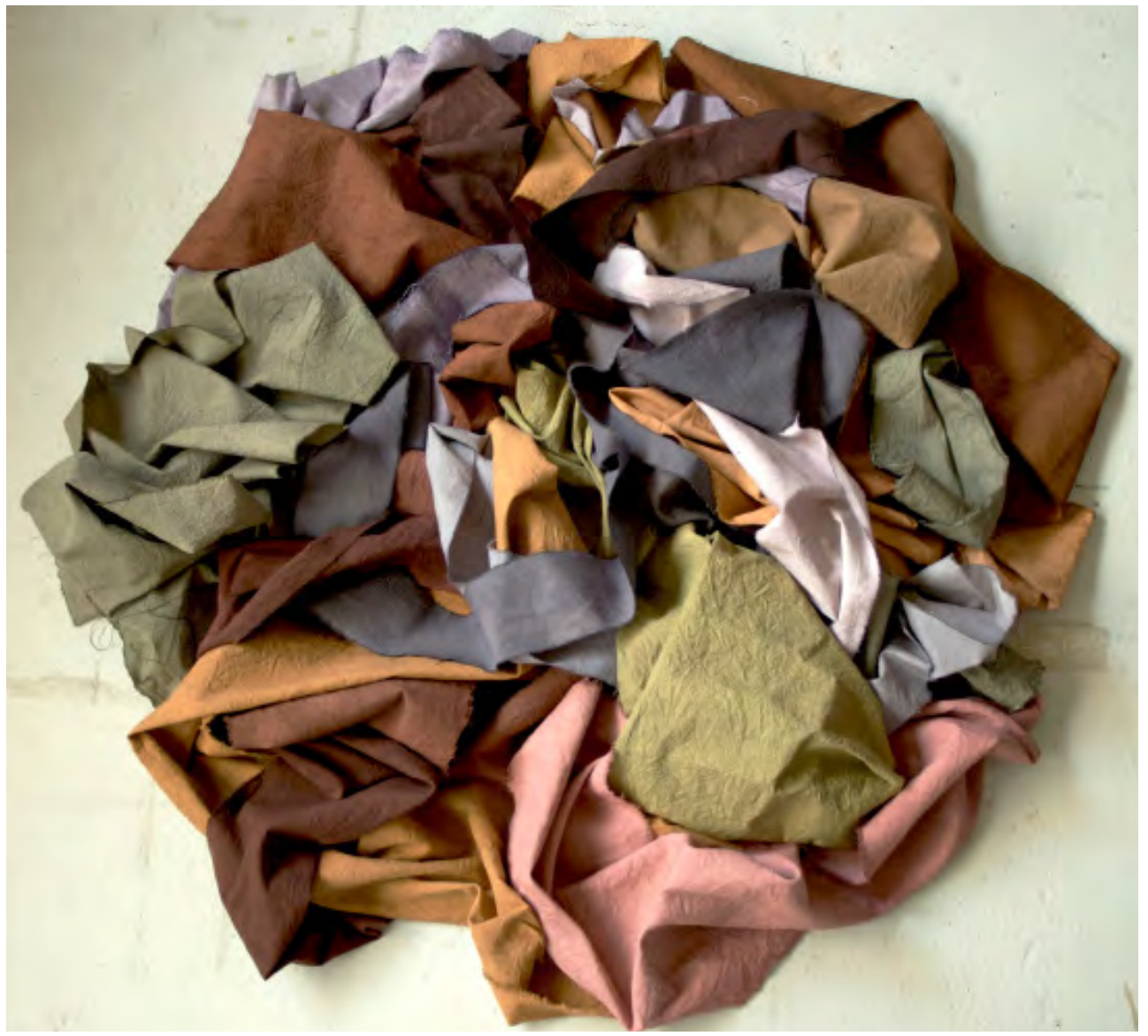

Desdobramento da baliza 2: Conserva - tecidos pintados (baliza 2) - 2011 e 2012. 


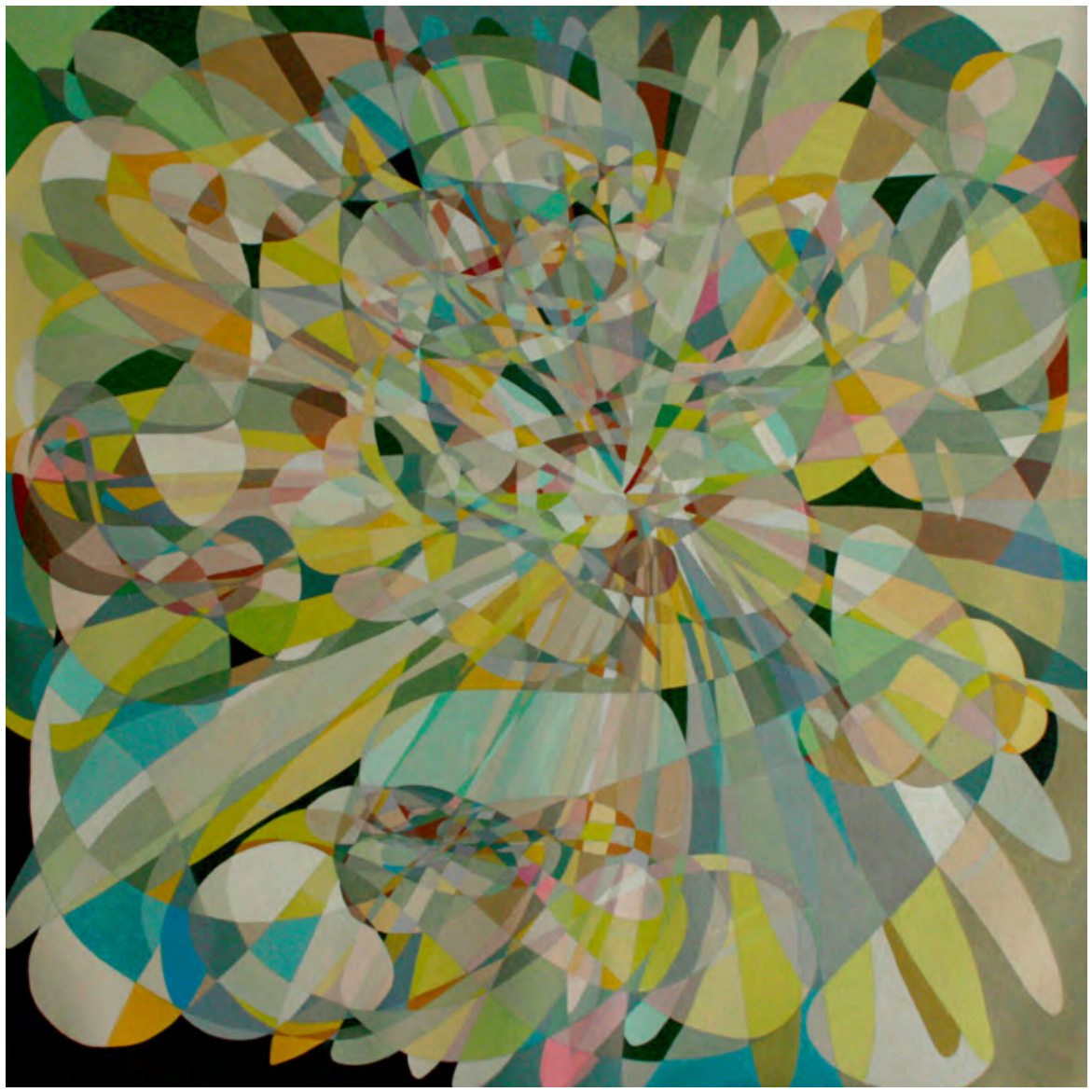

Temperança - tinta acrílica sobre tela - 2011. 
Como desdobramento do ciclo cinza-cor-de-pele, foram criados também os trabalhos: "Relevo", "Xícara de café, copo d'água, maçã e mosca" (ver DVD anexo) e as pinturas realizadas com aerógrafo de boca.

O primeiro, Relevo, se constitui de uma roupa feita com cacos de espelhos encontrados nas ruas, pregados sobre uma estrutura de viés de tecido costurada. O registro do trabalho em fotografia foi realizado em colaboração com Maura Grimaldi na cidade de São Paulo.

Xícara de café, copo d'água, maçã e mosca é um filme digital de cinco minutos que leva o olhar para elementos do cotidiano. Neste, os pequenos movimentos da mão conduzem a atenção do espectador para o "limite" invisível que separa os elementos do plano.

Ambos tratam de objetos do convívio diário (alimentos e roupa) passando agora, depois de todo o processo de pesquisa, por certo procedimento de desvio, do lugar habitual para um território de questionamento. 


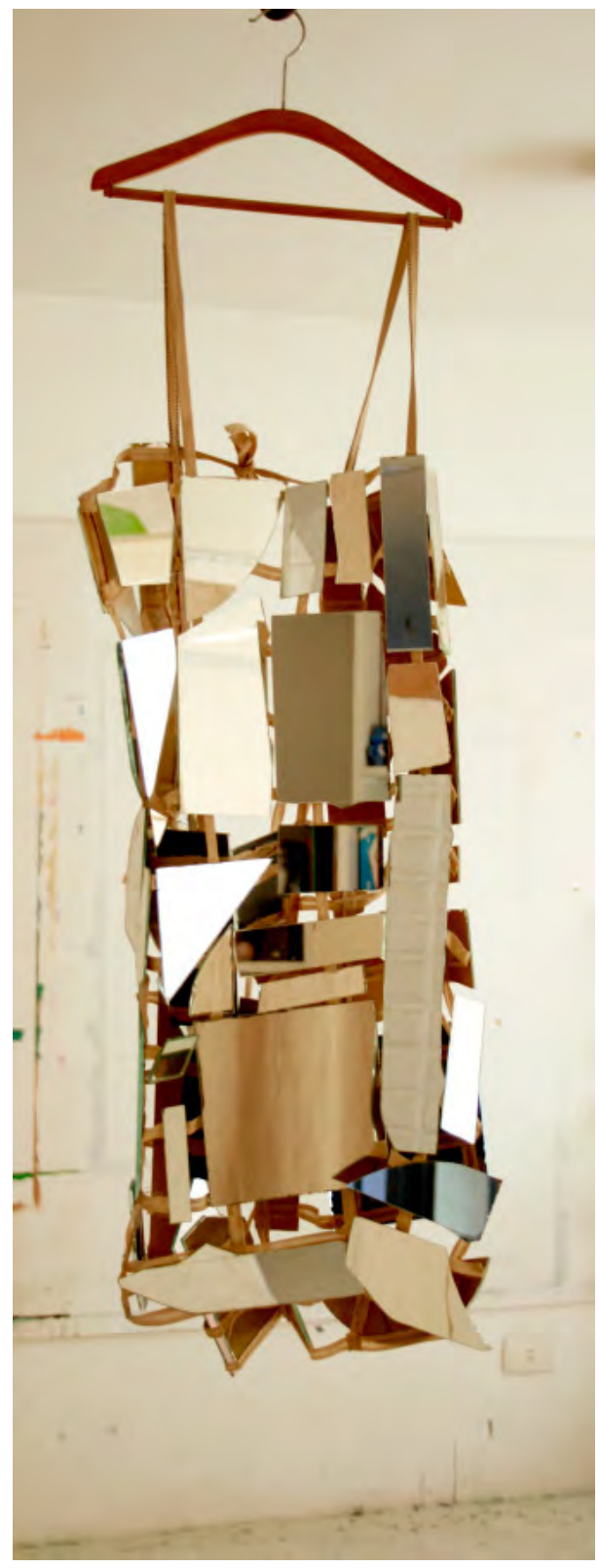




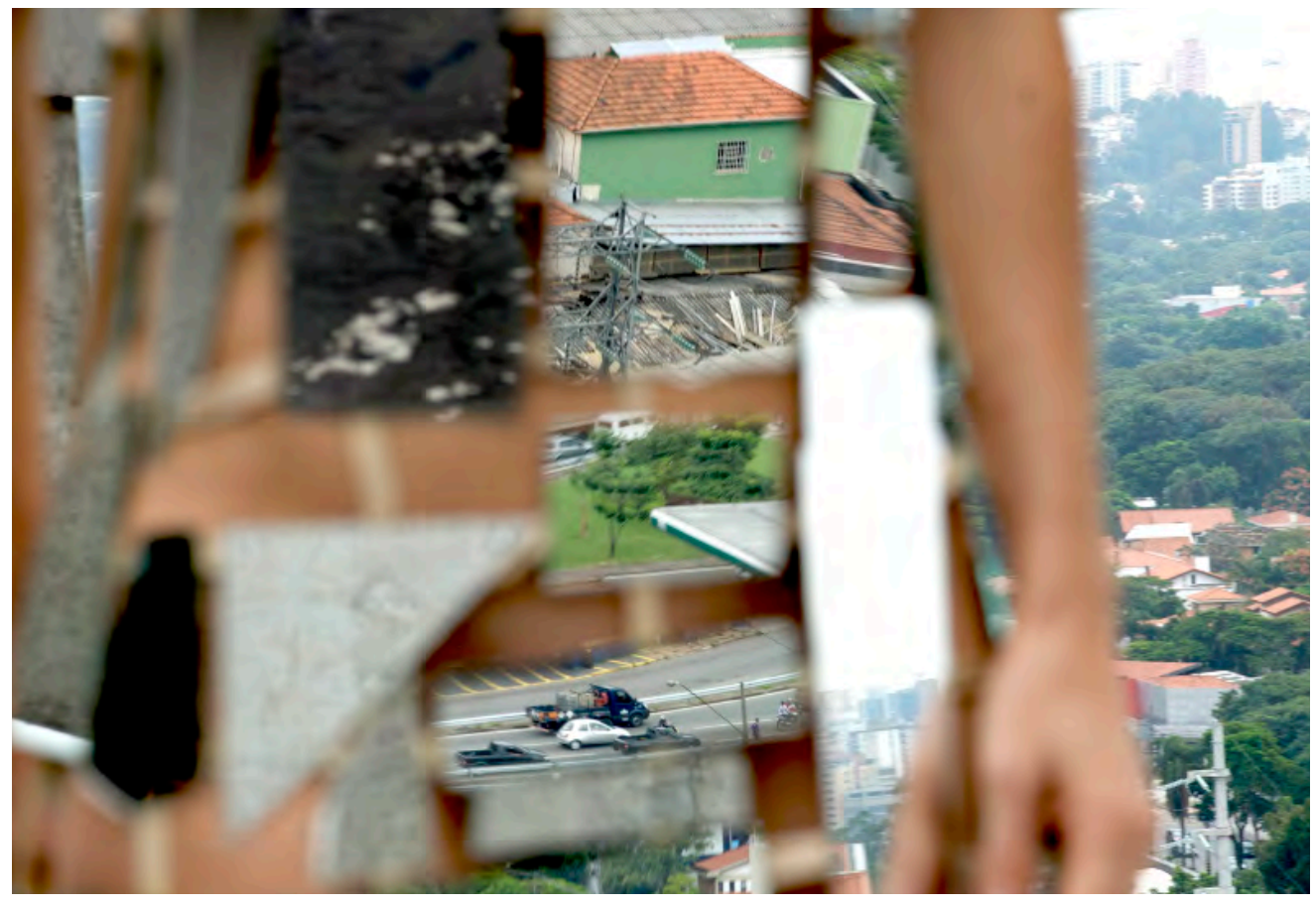

Relevo - fotografia Maura Grimaldi - 2012 
Com atenção nas passagens, nos dentros e foras, os últimos trabalhos realizados foram pinturas feitas com aerógrafo de boca. Uma técnica bastante antiga e, talvez, precária. Foi um momento chave o da escolha deste modo de fazer pintura. Para acontecer, precisava diretamente da atenção à respiração. Comunhão do corpo com a pintura. Cada expiração mudava a imagem. Intensidades que eu não controlava, mas das quais participava.

O cinza-cor-de-pele e seu campo de emanações: limites, transparências e opacidades. Urbano. 


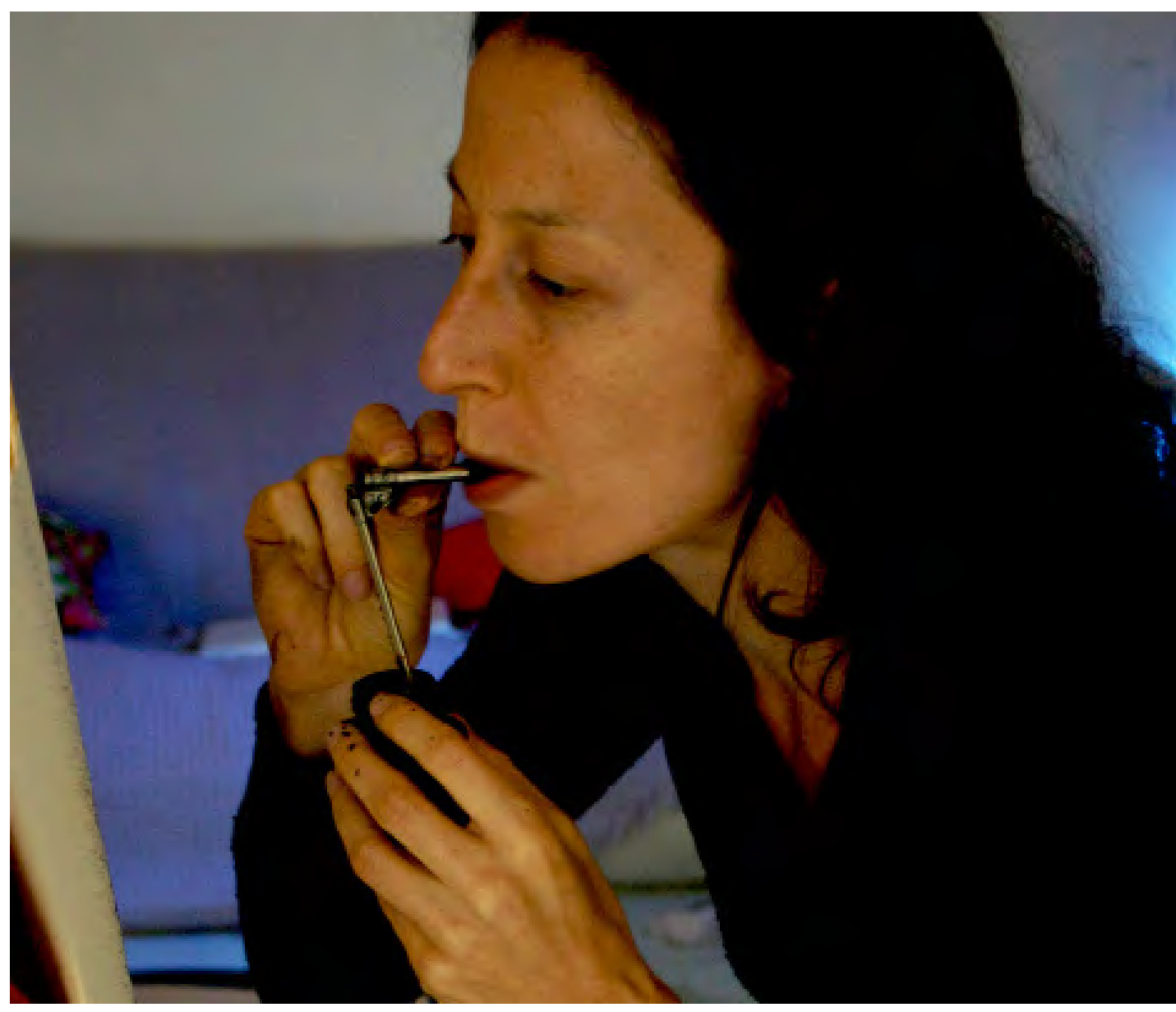

Processo das pinturas feitas com aerógrafo de boca. 


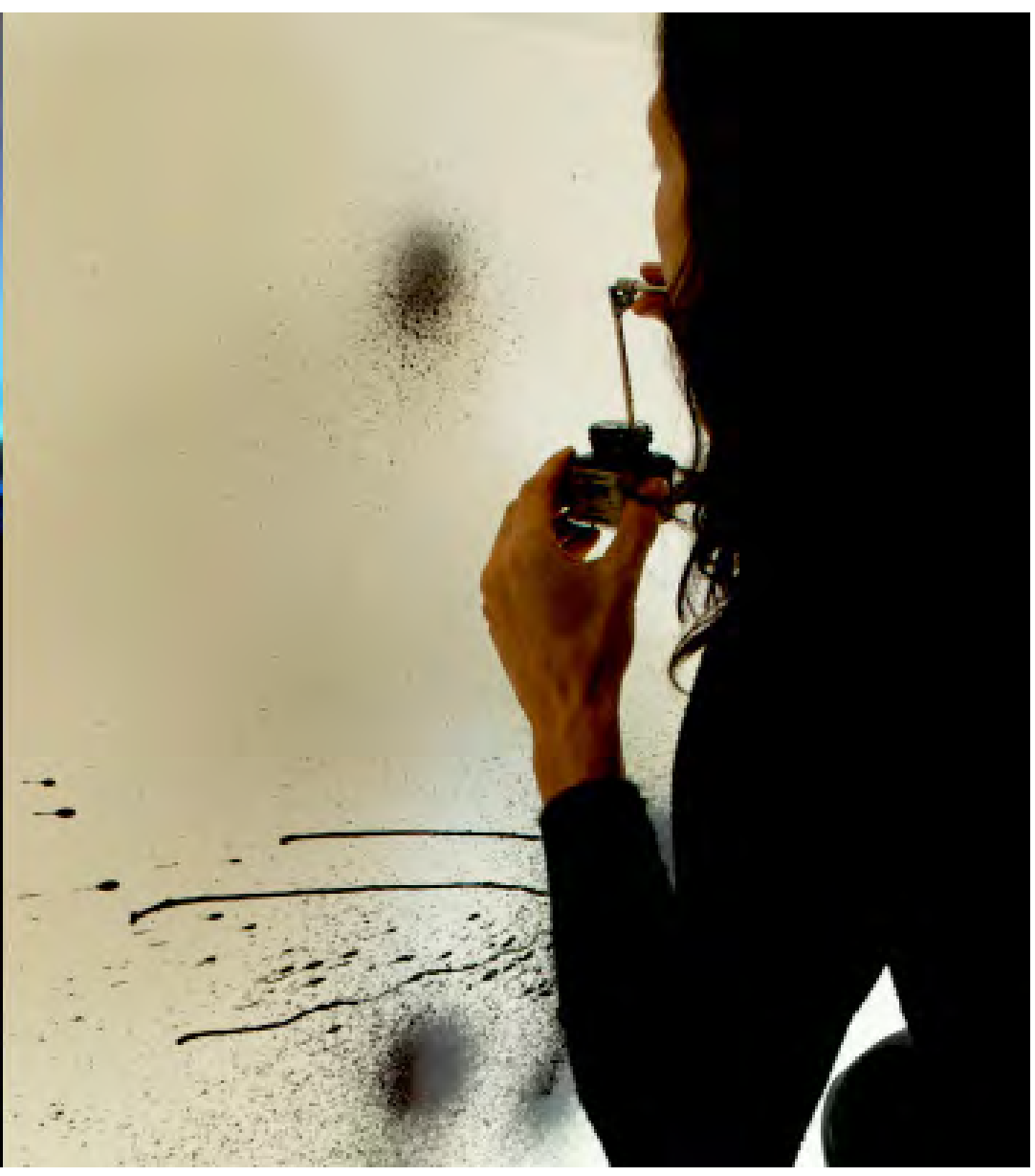




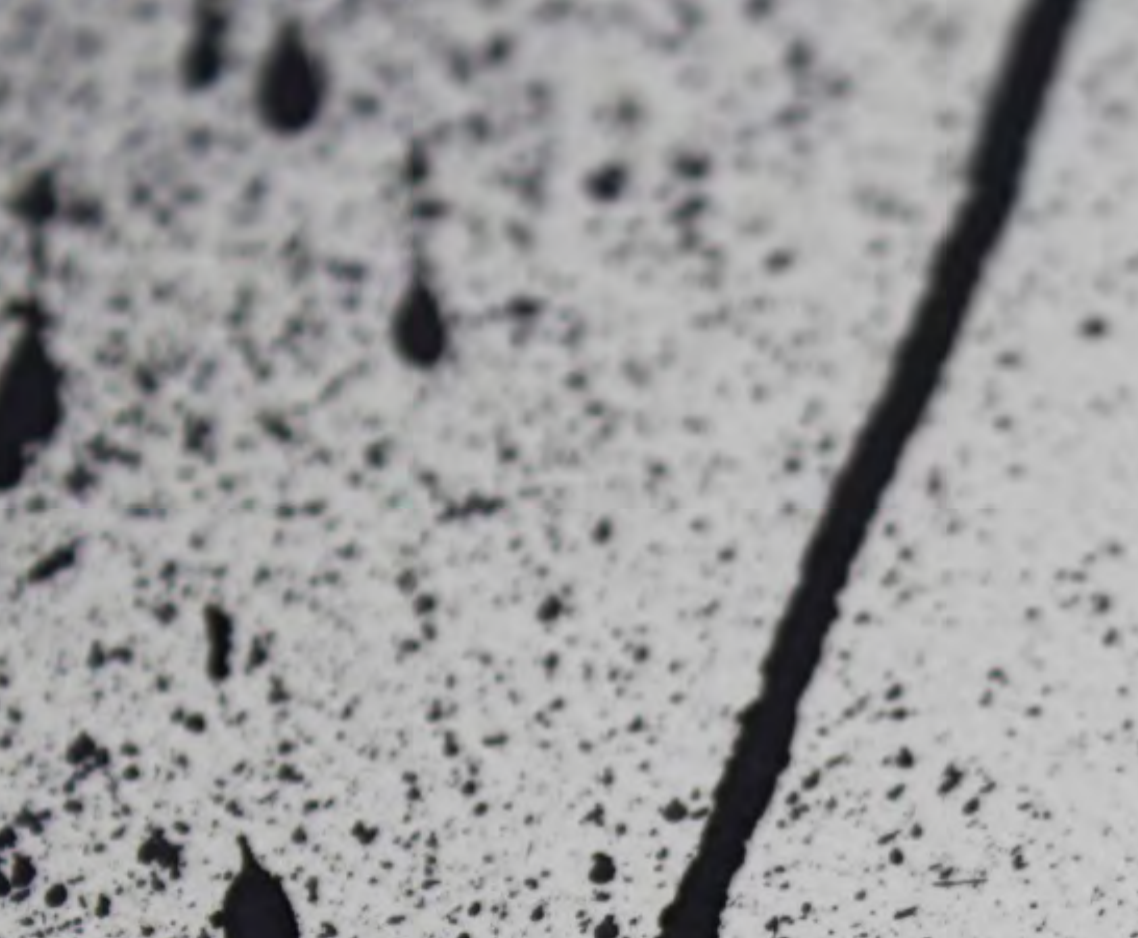

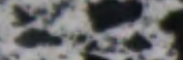

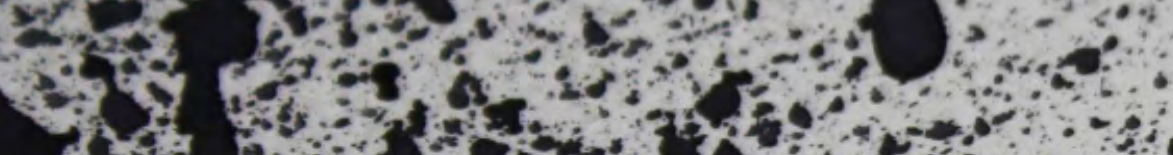
(1)

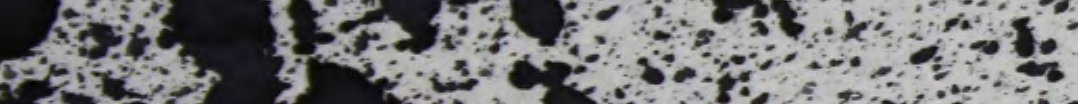

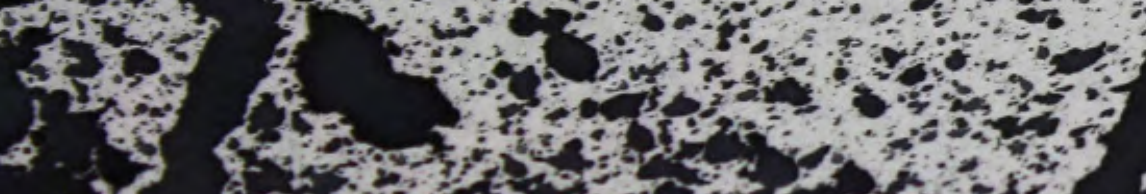
47 an,

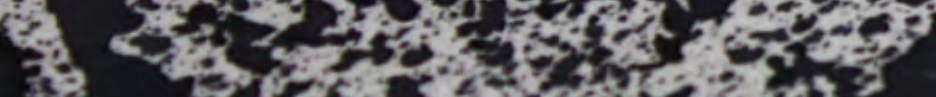
s. ato tostot

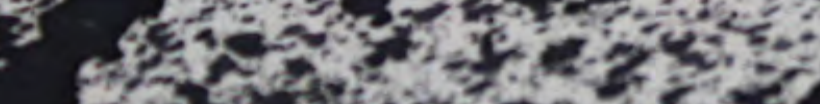

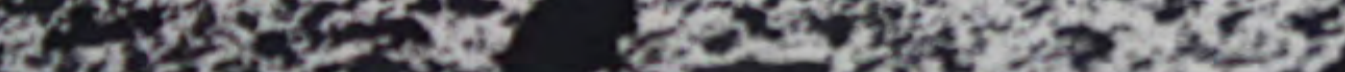

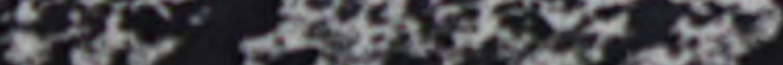

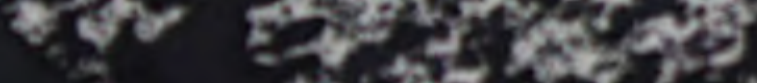

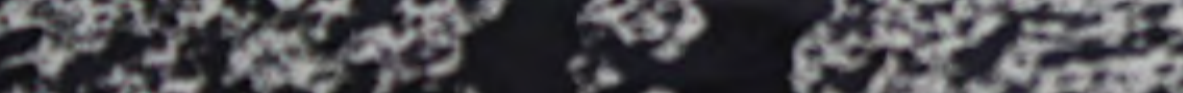

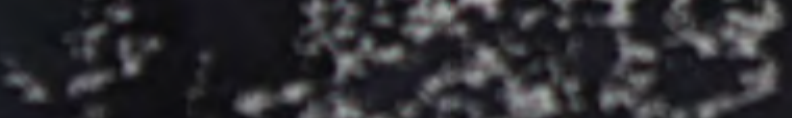
- 3 ar

$$
\text { spot? }
$$

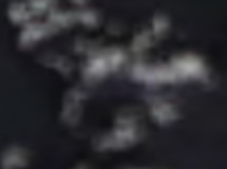

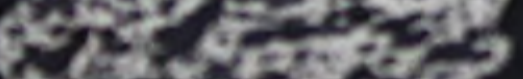

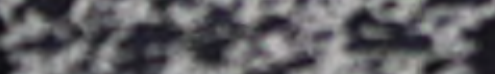

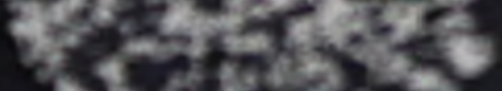

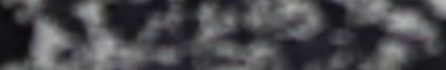

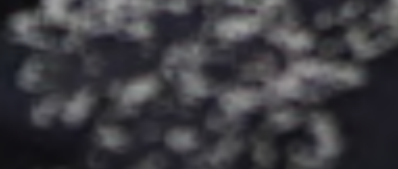





\section{Parte II}




\section{A percepção como instrumento}

Ser Bruto, não sendo um positivo, também não é um negativo, mas aquilo que, por dentro, permite a positividade de um visível, de um dizível, de um pensável, como a nervura secreta que sustenta e conserva unidas as partes de uma folha, dando-lhe a estrutura que mantém diferenciados e inseparáveis o direito e o avesso: é o invisível que faz ver porque sustenta por dentro o visível, o indizível que faz dizer porque sustenta por dentro o dizível, o impensável que faz pensar porque sustenta por dentro o pensável.

MARILENA CHAUI ${ }^{11}$

A percepção em meu processo criativo é via de acesso, possibilidade de comunhão com o entorno, que não se confunde com o contato racional. A percepção atua de maneira direta e diz respeito às raízes do comportamento, ao nascedouro das ações em direção à concretude do vivido. Na tentativa de tocar e ser tocada efetivamente, a cor e os pequenos movimentos do corpo foram estudados nesta pesquisa como ativadores do cotidiano e criadores de estados de presença e participação do sensível. Um estudo da permeabilidade, do que me atravessa ou, do que simplesmente passa.

Neste trabalho foram estudados conceitos e abordagens relevantes para este processo. O filósofo Maurice Merleau-Ponty (1908-1961) em a Fenomenologia da Percepção ${ }^{12}$, assume o corpo integrado, não organizado em partes isoláveis, estanques e a percepção como uma ferramenta de integração do sujeito consigo e com o mundo.

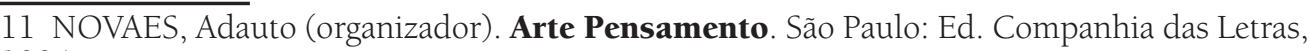
1994.

12 MERleAU-PONTY, Maurice. A Fenomenologia da Percepção. São Paulo: Ed. Martins Fontes, 2006. 
Neste capítulo, a partir de algumas reflexões desencadeadas pela leitura de Mereleau-Ponty e de outros estudos relevantes, a percepção é entendida como um dos instrumentos do artista plástico quando se coloca no campo performativo. A proposição é fazer um levantamento de certas qualidades e práticas quando se deseja o corpo como obra ou componente fundamental de um processo plástico ${ }^{13}$.

13 Ricardo Basbaum no texto Pensar Performance sugere o processo plástico como estratégia para mobilização em vários níveis das ações dos artistas performers, permitindo a conjugação de práticas do ver e do dizer, visualidade (atrelada à totalidade do corpo) e reflexão. (BASBAUM, R. Pensar em Performance. MAC-Revista, São Paulo, Museu de Arte Contemporânea, USP, n.1, abril 1992). 


\subsection{Limiar: a opacidade do observador}

Há uma imensa diferença entre ver uma coisa sem o lápis na mão e vê-la desenhando-a.

PAUL VALERY ${ }^{14}$

A visualidade é considerada em muitos estudos das artes plásticas protagonista dos sentidos. Na medida em que os procedimentos, comportamentos e posicionamentos dos artistas, pesquisadores e do próprio público diante da obra são percebidos enquanto força expressiva e transformadora do humano, quebra-se um paradigma e se faz necessária a consideração do corpo como um todo.

Um dos passos nesta direção ${ }^{15}$, foi a Doutrina das Cores de Goethe ${ }^{16}$ no século XIX. Neste estudo, apesar da visualidade ainda estar em primeiro plano, é sugerida uma passagem conceitual importante. Antes da Doutrina das Cores, os experimentos óticos estavam encerrados a experimentações externas ao corpo, aos meios translúcidos que deveriam funcionar de maneira análoga ao olho, como acontecia nos prismas de Isaac Newton (1643-1727), por exemplo. Ao sugerir que para ver as cores fechemos os olhos, Goethe propõe a mudança radical: as cores são também fisiológicas, dançam na retina como pós-imagens. Cores reverberam o corpo.

14 VALERY, Paul. Degas Dança Desenho. São Paulo, Ed. Cosac \& Naif, 2003.

15 CRARY, Jonathan. Techniques of the Observer. MIT Press, Cambridge, n.45, 1988.

16 GOETHE, Johann Wolfgang von. Doutrina das Cores. Tradução Marco Giannotti. São Paulo: Ed. Nova Alexandria, 1993. 
Se os discursos do visível nos séculos XVII e XVIII ocultaram e evitaram qualquer questão que ameaçasse a transparência do sistema ótico, com a análise de Goethe abre-se uma nova compreensão e coloca-se a opacidade do observador como condição do fenômeno visual ${ }^{17}$. Passa a interessar o olho em si. Podemos dizer que aqui começa (mesmo que de maneira insipiente) a interessar o corpo em si, seu funcionamento, sua inerente instabilidade física e temporal.

Se o observador é "opaco", há uma margem não claramente definida e certamente não fechada de passagem entre o externo e o interno que gera diferenciações e acontecimentos. Como paralelo, no desenho esta marca divisória seria a linha; no ser, trata-se de uma camada complexa e permeável: a pele, seus poros, as terminações nervosas e, como veremos também, o halo (campo que nos envolve imediatamente).

Portanto, foi a partir do século XIX e no século XX, com a Fenomenologia da Percepção ${ }^{18}$ entre outros estudos, que as artes visuais se apropriaram de conceitos que se tornaram base reflexiva para diversos artistas, principalmente nas décadas de 1960 e 1970. Por meio da percepção corporal, a margem que "separa" corpo e mundo passa a ser em si uma imagem a ser expandida, vivenciada, decifrada. Na Fenomenologia, que considera o corpo como um todo e a experiência como fundamento, o tátil passa a ser existencial, volumoso e o 
visual, a contra golpe, perde sua centralidade e se experimenta num movimento de integração ${ }^{19}$.

Numa reflexão que relativiza hierarquias tanto no que concerne à organização interna de nossos sentidos, como de nossas relações com os outros corpos, seres e objetos, propõem-se um corpo descentralizado e poroso. Para além de articulações ósseas, musculares, somos um emaranhado de articulações sensíveis em constante fluxo, tanto numa escala microscópica quanto na escala do social, ambiental.

19 Em questionamentos contemporâneos apontados por Rosalind Krauss e Yves-Alain Bois em Formless: a user's guide, 1997, leva-se em conta a organização hierárquica dos órgãos dos sentidos do corpo humano e propõe-se inversões numa atitude que os integra. O posicionamento dos olhos com relação à verticalidade da coluna é singular dos seres humanos, nenhum outro animal possui configuração semelhante: o olho para nós posiciona-se no alto, no topo. Propõem-se, então, uma desestruturação de tal organização, através da sensibilização e convocação do todo o corpo, lembrando e ativando sua presença, e rebaixando a centralidade da visualidade. A partir do momento em que o olho já não está à frente do processo perceptivo, há a possibilidade de um corpo equiparado ao mundo, com referências de pés descalços, talvez avesso, amorfo e difuso em relações horizontais. (BOIS, Yves-Alain; Krauss, Rosalind E./ Formless - a user's guide. Cambridge: New York Zone Books, 1997). 

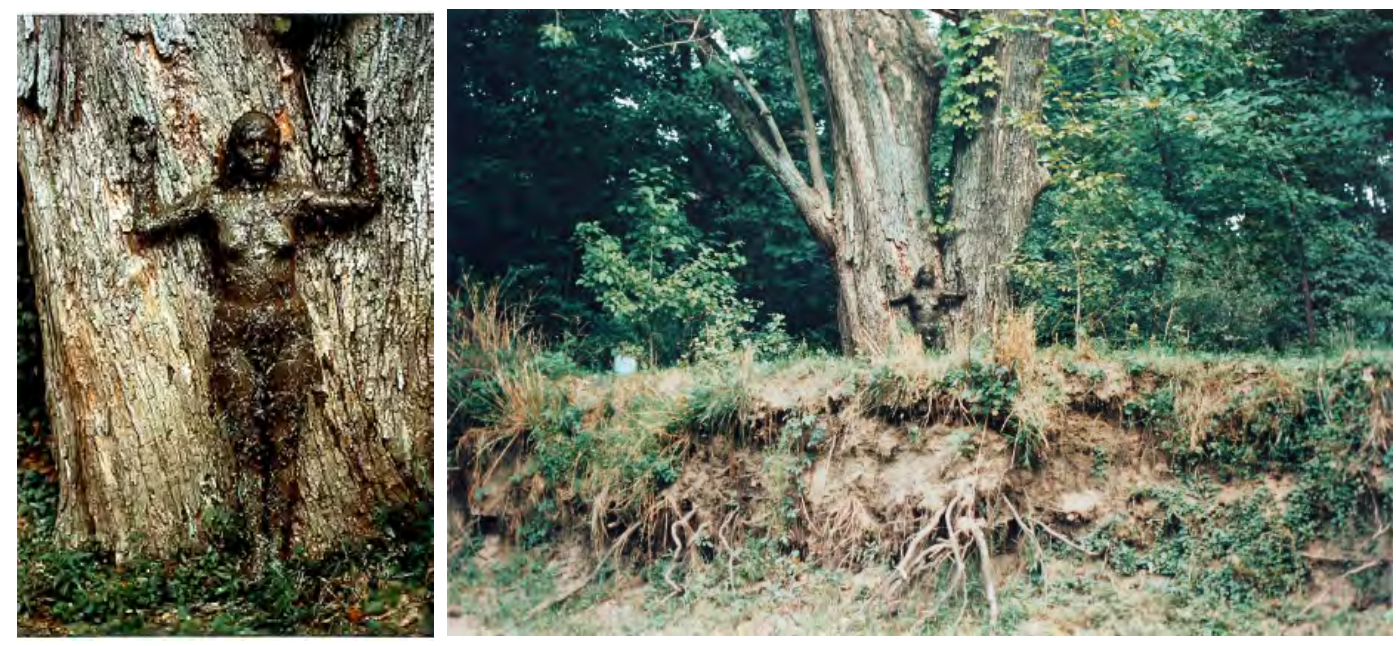

Ana Mendieta - sem título - 1977

A artista cubana numa série de trabalhos mimetiza-se com o ambiente. 


\subsection{Tátil-visual: o corpo performer}

Entre as possibilidades de estudos de relações sensório-motoras que o corpo desvela, esta pesquisa se detém na tátil-visual. Na história da arte, certos pesquisadores $^{20}$, a partir do século XVII desenvolveram teorias a respeito desta relação. No século XVIII, vem à tona o interesse pelo estudo de cruzamentos perceptivos como se estes contribuíssem para o conhecimento de processos intuitivos.

A referência conceitual do presente trabalho será o tátil-visual percebido tanto na comunhão corpo-mundo, como sugerimos no tópico anterior, quanto na síntese do corpo próprio, como veremos a seguir.

Na síntese do corpo próprio, o olhar dá conta de perceber os membros, a barriga, a ponta do nariz, talvez um pedaço das bochechas; e o tátil completa o que o campo visual não atinge, as costas, a parte interna da orelha, a cavidade da boca... O corpo visual e o corpo tátil se complementam, se trocam.

O reconhecimento que tenho de meu corpo parte de um agenciamento destes sentidos. De modo que, por vezes, reconheço minha silhueta numa filmagem (imagem que não consigo ver no cotidiano) e, por outras, não posso reconhecer a minha própria mão numa fotografia (imagem que está no meu campo visual $)^{21}$. Não se trata da tradução de um sentido para o outro, nem da reunião das partes, uma a uma. Mas sim, de um processo que acontece de uma só vez: este é meu corpo.

20 Podemos citar aqui os pesquisadores Adolf Hildebrand (1847-1921) e Alöis Riegl (18581905). Em Hildebrand, fala-se da relação tátil-visual imbricada no processo de percepção do espaço; em Riegl, como desdobramento dos estudos daquele, cria-se um conceito: o háptico, que se relaciona a certa capacidade de cruzamento perceptivo do tátil com o ótico.

21 MERLEAU-PONTY, 2006, pp.279-325. 
Para Merleau-Ponty, a relação tátil-visual aparece como estruturante da percepção humana e também como afirmação da existência de um lugar intersensorial. Ou seja, “(...) não há no sujeito normal uma experiência tátil e uma experiência visual, mas uma experiência integral em que é impossível dosar as diferentes contribuições sensoriais²2."

Na presente pesquisa, o corpo é percebido por esta comunhão do tátil e do visual. E, para ser ativado e tido como componente vivo da criação, pede o estudo dos pequenos movimentos que o compõe para que constantes afinações possam ser trabalhadas como ponto de partida da obra, como estado não mecânico de expressão e pesquisa.

O sentido tátil necessita do tempo para se desenrolar. É no passar de minha mão sobre uma superfície que reconheço suas reentrâncias e saliências. A visão acontece aparentemente de um só golpe, mas sabemos que o processo de formação de imagens e pós imagens também se dá no tempo. No entrelaçar destes acontecimentos, destes pequenos movimentos, cria-se uma temporalidade do sensível e um campo de experimentação. "O tempo é o sentido da vida (sentido: como se fala do sentido de um córrego, do sentido de uma frase, do sentido de um tecido, do sentido do olfato) ${ }^{23}$." 


\subsection{Pequenos movimentos: praticar percepção}

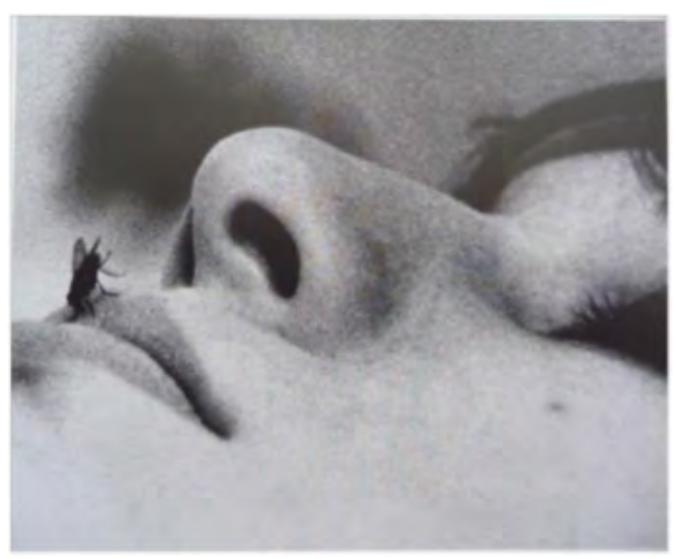

Yoko Ono - Fly - 1971

A percepção deve ser trabalhada, ampliada, a partir do pequeno movimento, do delicado, para mais tarde ser também do intenso. Se a língua investiga a cavidade da boca, conta os dentes; se o ar preenche os pulmões, amacia; se a blusa cobre as costas, esquenta... são os pequenos movimentos que me colocam em determinado estado, que me abrem à experiência perceptiva e fazem desta uma trilha acessível, um caminho que se cria e pode ser revisitado, explorado.

Os pequenos movimentos foram estudados e tiveram relevância nas pesquisas e práticas do engenheiro e físico Moshe Feldenkrais²4 (1904-1984).

24 Moshe Feldenkrais foi um dos pioneiros da educação somática e contemporâneo de outros educadores: Frederick Matthias Alexander (1869-1955), criou a Técnica de Alexander fundamentada na importância de uma boa postura, de uma reorganização dos padrões habituais do corpo para o bem estar do ser humano; Gerda Alexander (1908-1994), criou a Eutonia que colocava o foco no tônus corporal e suas constantes adaptações; e Ida Pauline Rolf (1896-1979) foi bioquímica e criou a chamada Integração Estrutural ou Rolfing que tinha como principal objetivo organizar a estrutura do corpo em relação à gravidade e para tal, investigou profundamente a importância dos tecidos do corpo humano, principalmente das fácias. 
Partindo do pressuposto que o corpo não deve ser exercitado por meio de repetições mecânicas, Feldenkrais colocou uma lupa em cada ação realizada, nos detalhes dos movimentos, levando em conta a importância da singularidade de cada gesto no seu mínimo e da experimentação em si como possibilidade do desenvolvimento da flexibilidade, não da musculatura, mas do ser. Compreendeu que muitos dos problemas que surgem no corpo estão relacionados a hábitos comportamentais, incluindo aspectos cognitivos, motores e ambientais.

No momento em que uma ação é realizada com atenção, vivida em suas sutis diferenciações, a percepção gera movimento e o movimento gera percepção. Movimentos pequenos e repetições experimentais são então a possibilidade de um corpo criar-se por meio do sensível, com parâmetros e limites próprios. Não de um "ideal de forma" ou de uma amplitude imposta, como foi exercitado pelo pensamento da ginástica, principalmente no século XIX ${ }^{25}$ e ainda hoje.

Nesta abordagem somática, a criação está atrelada a um certo rebaixamento proposital de padrões contraídos. Não que haja um apagamento dos movimentos habituais. Estes, que num primeiro momento são a única possibilidade, tornam-se por meio das práticas, uma, entre tantas outras. Assim, caberá a cada indivíduo escolher, dentro de um repertório criado, a trilha para cada circunstância vivida, num processo dinâmico de observação e afinação.

Uma outra referência que contribui com a reflexão sobre os pequenos movimentos é o infra mince ${ }^{26}$ de Marcel Duchamp (1887-1968). Temos acesso a esta ideia por meio de sessenta e quatro breves notas escritas pelo artista e

25 SOARES, Carmen Lúcia. Imagens da Educação no Corpo: estudo a partir da ginástica francesa do século XIX. Campinas: Ed. Autores Associados, 2002.

26 De acordo com Duchamp, na medida em que infra-mince é uma manifestação existente coube a ele descobrí-la, refletir a respeito e não inventá-la. É possível comparar o infra-mince ao infra-vermelho ou ao ultra-violeta, vibrações que existem mas que não vemos. Para percebe-las é preciso certo exercício, certa atenção, sensorial e mental. 
publicadas postumamente nos anos 1980. O infra mince, refere-se a entidades mínimas, que surgem, ou são agentes, das relações entre coisas ${ }^{27}$. Diz respeito então aos pequenos movimentos que se dão a partir da relação entre corpos, idéias, instâncias. É talvez, o próprio entre: apesar de quase imperceptível, é objetivamente existente.

O infra mince aparece nas notas de Duchamp de diferentes formas sendo que, de uma maneira ou de outra, sempre escapa, faz-se rastro, seja pela impossibilidade de uma definição precisa, seja por seu caráter de instantaneidade: "O calor de um assento (que acaba de ser deixado) é infra mince"28. As manifestações que estariam relacionadas a esta ideia são variadas mas obedecem princípios comuns, admitindo como relevante o tênue, à revelia do exagerado, do espetacular.

Uma pincelada, um traço do lápis, bem como o escorregar dos olhos pela paisagem, as mãos que pressionam a argila, a atenção ao corte preciso da madeira... Há uma prática cotidiana do gesto nas artes plásticas. Práticas de pequenos movimentos e manipulações que, com o tempo, se traduzem em corpo.

No livro The Body of the Artisan - Art and Experience in the Scientific Revolution, Pamela H. Smith ${ }^{29}$ discorre a respeito da importância de processos corporais no artesanato no norte da Europa, na Idade Média ${ }^{30}$.

27 OlAIO, Antonio. Ser um Indivíduo Chez - Marcel Duchamp. Porto: Dafne Editora, 2005, pp.160-161.

28 DUCHAMP in: OLAIO, 2005, pp.160.

29 SMITH, Pamela H. The Body of the Artisan - art and experience in the Scietific Revolution. Londres: University of Chicago Press, 2004.

30 No livro de Amelia Jones The Artist's Body diversos textos e imagens compilados, bem como reflexões da autora, delimitam o que para ela compõe o corpo do artista. Uma abordagem ampla e contemporânea que aqui não foi incluída diretamente por escolhas conceituais e brevidade da presente pesquisa. Torna-se indispensável entretanto citar a importância de tal publicação para o contexto das artes performativas. 
O aprendizado, por exemplo, da fabricação e mistura dos pigmentos passava por uma observação e contato atento com os materiais, seus comportamentos e efeitos posteriores. Por serem processos artesanais, cada trabalho realizado, cada gesto, admitia e afirmava existência. Não se tratava de procedimentos fabris, de grande escala e alta velocidade, mas sim, de um modo de fazer que absorveu certo legado de outras práticas, como as alquímicas e médicas, nas quais o fazer preocupa-se minuciosamente com a qualidade de sua realização.

Estas práticas corporais exigiam acuidade na observação de detalhes e na manipulação. Levava-se em conta a contemplação, a intuição e as circunstâncias. Para chegar em determinada cor, por exemplo, era necessário conhecer cada componente, suas variações, suas reações com outros elementos e também com o corpo, bem como seu comportamento em determinado ambiente, temperatura etc. Em um dos relatos, Smith cita o depoimento de um artesão que disse ter demorado anos para descobrir que seria melhor não fazer o temperamento dos cinzéis numa manhã fria.

Em documentos estudados, a autora constata também que a repetição era parte fundamental dos processos daqueles corpos. Para o artesão, a repetição seria tanto a cópia de técnicas corporais dos mestres, como a incorporação de processos naturais. Desejava-se apreender, absorver no corpo, as metamorfoses e fluxos que compunham todo o processo: das reações químicas dos componentes às manipulações tradicionais precisas dos mestres.

Aprender, por exemplo, a transformar-se como a água: do líquido ao gasoso. Absorvia-se assim, temporalidades. Comunhão entre os pulsos do corpo e dos fenômenos observados. Isto é diferente de imitar uma forma, trata-se 
de transformações que acontecem no tempo de maneira recíproca, de incorporação de um procedimento e da investigação da complexidade que o envolve.

Num outro exemplo, a autora conta que elementos como a urina ou a cera do ouvido podiam ser utilizados na fabricação de componentes de trabalhos. Havia, portanto, um investimento, um envolvimento físico. Elementos do corpo poderiam tornar-se parte de uma obra e o fazer da obra transformaria o corpo do artesão. Em alguns casos extremos, esta relação com os materiais levava certos artífices à morte prematura pelo contato direto ou inalação de componentes insalubres.

Seja por meio da abordagem corporal de Feldenkrais, pelos exemplos de Pamela H. Smith, ou pelo infra mince de Duchamp, retoma-se aqui o corpo que se constrói em práticas artesanais, em pequenos movimentos atrelados intencionalmente à percepção. Comunhão entre corpo e obra, corpo e mundo, num recriar-se constante em acontecimentos sutis.

Nestes processos que são poéticos em si, fica difícil delimitar onde está a obra: no objeto, no corpo de quem as realiza? Talvez esteja no conjunto de movimentos, discursos e relações que acontecem em torno e junto da obra-corpo. $\mathrm{O}$ artista belga Francis Alÿs sugere que seus trabalhos, caminhadas, pinturas, ações... são como constantes ensaios, nunca se encerram, estão sempre passíveis de repetição e recalibragem.

As artes performativas muitas vezes sugerem um deslocamento do olhar para o processo, para as ações, enquanto obra. Na medida em que o corpo é movimento constante, corpo é processo contínuo, corpo é obra, seu fazer-se é também poética. Corpo modelado pelo próprio artista, que escolhe atitudes 
que o compõe, e também participador de acasos desdobrados por movimentos dos contextos e encontros vividos. Interno e externo se encontram e se retroalimentam, partilham. 


\subsection{A cor: o que vaza, o que infiltra}

Os pequenos movimentos, os movimentos sutis, ao ocuparem o espaço entorno, se propagam, criam o que chamo de halo: camada para além de nossas peles, pele de emanações, que são também nosso corpo ${ }^{31}$. Ou talvez, o que esquecemos dele, como sugere certos aspectos da idéia de infra-mince.

Gestos criam um preenchimento do corpo no entorno imediato, densidade que se pode expandir e contrair. Este halo, num exemplo, é a sensação que temos ao aproximar nossas duas mãos reservando alguma distância entre elas. Se colocarmos ali a atenção, percebemos calor, volume, uma qualidade. Ou seja, uma reverberação que nos "encorpa", que de certa forma nos escapa, mas nos constitui.

Na medida em que este halo se torna perceptível, nos damos conta também de que a sua itensidade acontece não apenas no sentido de expansão, mas também de aproximação, de interiorização. Espesso e poroso. Não existe um lugar delimitado como superfície de passagem, mas um véu de nuances. O halo qualidade similar a da cor no sentido em que, diferente da linha, diz respeito às intensidades, à certa atmosfera e não ao que tem borda certa. Diz respeito às vibrações, aos pulsos e não ao que é rígido, unidirecional e estável.

31 Aproxima-se desta imagem a idéia de cinesfera proposta por Rudolf Laban (1879-1958). A cinesfera é o entorno do corpo do ser movente, os pontos do espaço que a pessoa pode alcançar sem deslocar-se. 


\subsection{Atmosfera: meias-tintas}

Por isso não fixei os traços, espalhei sobre os contornos uma nuvem de meias-tintas louras e quentes que faz com que não se possa com precisão colocar o dedo no lugar em que eles se confundem com o fundo. De perto, esse trabalho parece nebuloso e como que falta de precisão; mas a dois passos tudo se afirma, se detém, se destaca: o corpo gira, as formas tornam-se salientes, sente-se o ar circular em torno.

HONORÉ BALZAC 32

Em certas pinturas, o uso da cor no campo bidimensional, difere do desenho, da linha, no momento em que revela por meio do encontro de tons uma certa ambiência. Quando uma pintura é livre de linhas, de grades, quando se dissolve em meias tintas, passagens de claros e escuros, ou ainda, de maneira mais radical, torna-se uma única cor, como o caso dos monocromos, perdese a possibilidade de identificação rígida de contornos. Tem-se um campo de intensidades, atmosférico. Mesmo que uma pintura seja figurativa, se parte de uma construção em que os contornos não são definidos por linhas mas por metamorfoses cromáticas, pode revelar certa ambiência.

Nesta atmosfera, o espaço perde suas referências tridimensionais, bem como o tempo perde o sentido linear. Como numa noite muito escura, manchas de luz permitem ver pouco de nossos corpos e do que está envolta. A noite entra no corpo e o corpo na noite ${ }^{33}$.

32 Fala da personagem Frenhofer in: BALZAC, Honoré de. A Obra-Prima Ignorada: novela. São Paulo: Ed. Communique, 2003, pp.33.

33 MERLEAU-PONTY, 2006, pp.380-381. 
Não se trata, no entanto, de ver apenas a imagem nesta qualidade dissolvida, mas sim de amplificar esta qualidade para todo o corpo. "O azul é aquilo que solicita de mim uma certa maneira de olhar, aquilo que se deixa apalpar por um movimento definido de meu olhar. Ele é um certo campo ou uma certa atmosfera oferecida à potencia de meus olhos e de todo o meu corpo."34

Yves Klein ${ }^{35}$, sugere que pulverizou a barreira da forma em sua pintura e confirma que assim suprimira o espaço que existe na frente da tela, no sentido que a presença da pintura invade tanto o espaço quanto o observador. Força sensorial e integrativa da cor. Cada tom reverbera qualidades próprias e traz efeitos estimulantes, paralizadores, etc.

Uma passagem: o olho. E milhões de passagens: os poros, as terminações nervosas. Seja pela pele, pelo halo próximo ou pelo olhar que pode ir longe... são diversas as passagens e possibilidades de organização dos fluxos do corpo em suas relações com o mundo.

$\mathrm{Na}$ presente pesquisa não importa acertar ou não o gesto, repetir bem ou não as temporalidades da natureza, mas sim levar a atenção para as relações sensíveis do corpo e seus pequenos movimentos, emanações. Exercitá-los cotidianamente e fazer disto uma prática de afinação para um contato direto com o mundo, não arraigado em hábitos e contrações desnecessárias. Interessa o desvelar, o vir a ser de ações e qualidades corporais, desencadeadas por processos que envolvem a amplificação do tátil-visual. O que se têm como conseqüência material, formal, são como pistas, auxílios reflexivos e portas de entrada de compartilhamento das vivências, das experimentações. 
Em determinado momento da minha formação na graduação nas artes plásticas $^{36}$, já nos últimos anos, lembro-me de ter chegado atrasada à aula e ao entrar no ateliê, os colegas, cada um em seu espaço, realizavam seus trabalhos. Fiquei ali de pé, na porta, observando: que corpos são estes? Havia algo de específico e especial que se diferenciava das qualidades que vivenciara na dança, no circo, no teatro... Quais seriam estas qualidades? Os movimentos que executavam eram mínimos. Existia tom naquela circunstância, uma relação com o tempo, com a atenção, com a matéria, com as escolhas, precisões e imprecisões... Os detalhes trabalhados manualmente percorriam de alguma forma todo o corpo. Não eram corpos "abandonados" como um olhar de fora poderia sugerir, mas sim sustentados: pulsos e quietude.

36 Realizei duas graduações: Comunicação das Artes do Corpo com especialização em Performance (conclusão em 2005 - PUCSP), trabalho final orientado por Toshi Tanaka; e, Artes Visuais com bacharelado em Escultura (2008 - USP), Trabalho de Conclusão de Curso orientado pela Prof. Dra. Ana Maria de Araújo Tavares com foco em estudos das Artes Performativas. 

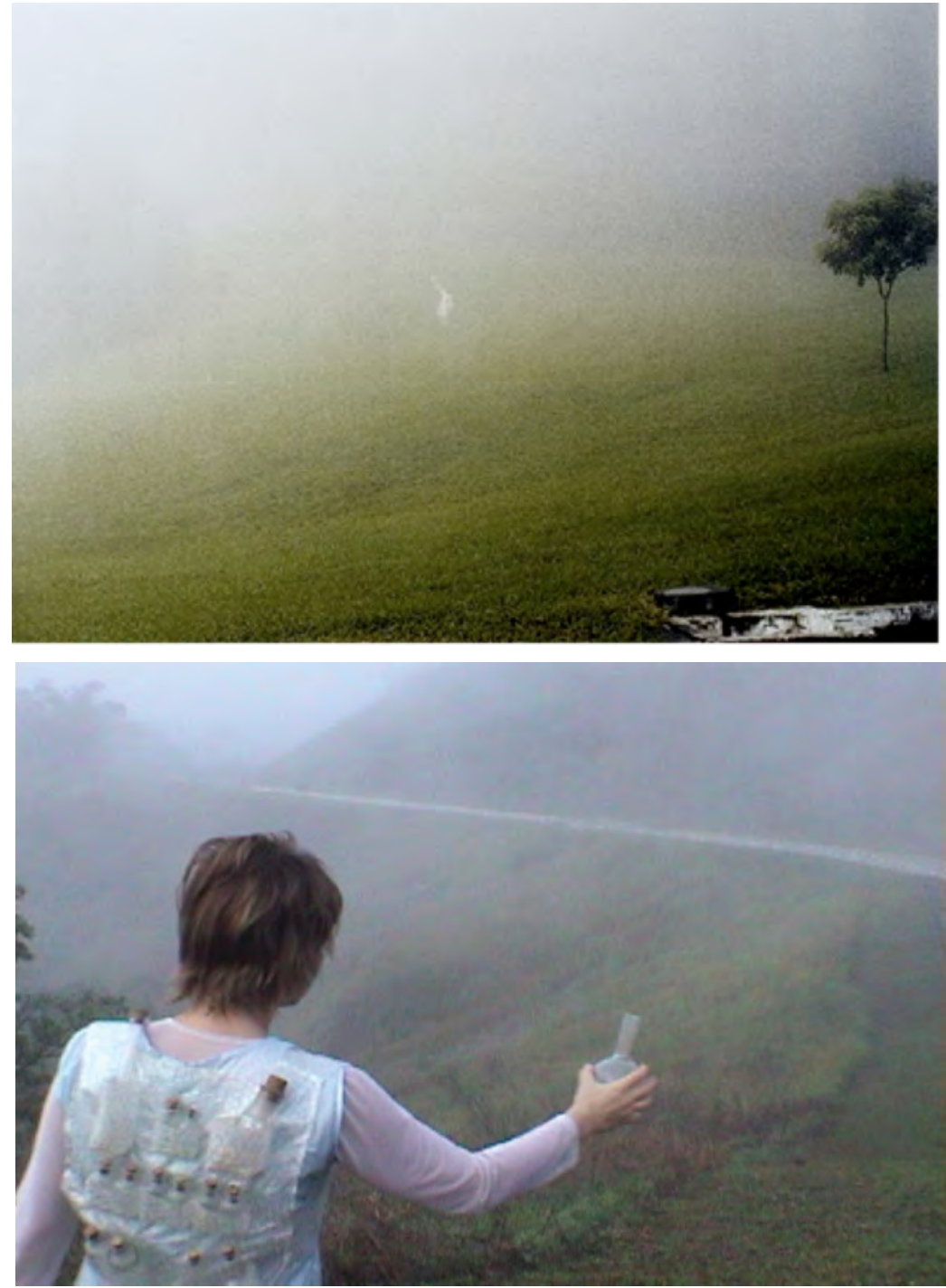

Brígida Baltar - Umidades: Coleta de Neblina - (2004/2001).

Nesta trabalho (sequêencia de fotografias) a artista brasileira, realiza repetidas vezes a ação de coletar neblina em diversos lugares e colecioná-las. Na primeira imagem, seu corpo quase que se perde e se mistura com o ambiente. 


\section{Experimentações cromáticas: corpo e pigmento}

Algumas manifestações estéticas podem ser vistas à luz de noções elaboradas nos tópicos anteriores: a pintura corporal da nação Kadiwéu, de maneira específica a do rito de passagem da adolescência para a fase adulta; as Antropometrias da Fase Azul (1960) de Yves Klein (1928-1962); e Roda dos Prazeres (1968) de Lygia Pape (1927-2004).

Os exemplos a seguir tratam do corpo em estratégias de encontro com a cor. A presença destas materialidades - corpo e pigmento - e suas maneiras de conjugar, fundir e interagir aparecem como componentes de três diferentes poéticas que relacionam-se à prática da pintura.

Na medida em que a cor tinge o corpo, pigmento e pele podem se amalgamar, transmutar... Neste momento revela-se a possibilidade de olharmos para o humano numa condição avessa, borrada, des/protegida. A pele vem à tona enquanto superfície, ao mesmo tempo que esta superfície borra, questiona seus limites e se sensibiliza.

O contato bruto com a matéria cor, com o pigmento, evoca o tátil-visual e o halo, apontados no capítulo anterior. Corpo humano em estado de vibração, de fluxo, movimento, in/quietude e, nos exemplos a seguir, ritual. 


\subsection{Uma pintura corporal da nação Kadiwéu}

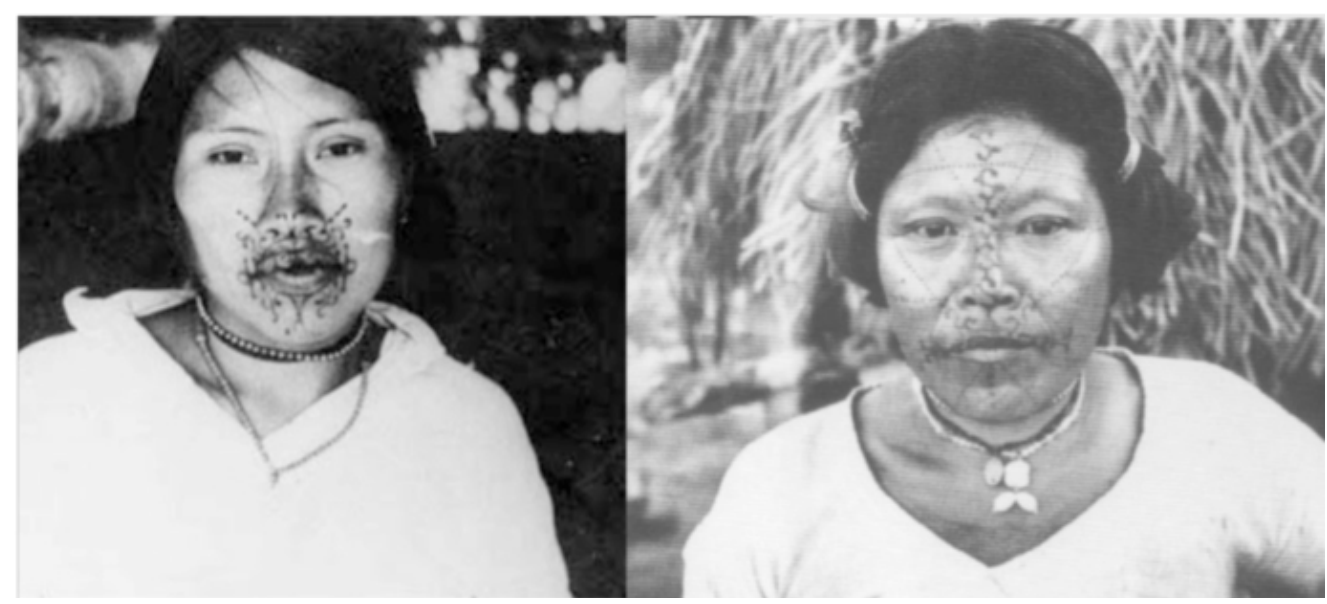

Imagens da pesquisa de Claude Lévi-Strauss - mulheres Kadiwéu pinturas do cotidiano. ${ }^{37}$

No início do século XX, o etnólogo francês Claude Lévi-Strauss (19082009) realizou uma longa viagem pelo Brasil, observou as comunidades tradicionais brasileiras e fez um inventário de manifestações típicas que eram muitas vezes análogas às supostas formas de expressão de comunidades pré-históricas no que concerne à pintura corporal.

Homens pré-históricos, além de terem realizado pinturas rupestres em diversos lugares do mundo, utilizaram-se dos diferentes pigmentos naturais para cobrir e adornar seus corpos, geralmente com finalidades rituais em manifestações individuais ou coletivas que diziam respeito aos universos mítico e mágico.

37 Não foram encontrados registros fotográficos do exemplo que citaremos neste texto relativo ao rito de passagem da puberdade dos meninos Kadiwéu. Assim, as imagens acima aqui estão a título de contextualizar o exemplo citado. 
Os pigmentos naturais eram produzidos a partir de terras, folhas, raízes, cascas de árvores, seivas, frutos e minerais. As cores sobre a pele entretanto não perduraram como prova em nenhum homem ancestral pré-histórico, decompuseram-se junto aos corpos, ou seja, nada pode ser afirmado categoricamente a respeito.

Nos documentos de Lévi-Strauss ${ }^{38}$, é possível vislumbrar de que maneira a pintura corporal em certas comunidades está atrelada a uma complexa rede de signos e símbolos culturais. Uma das descrições de pintura corporal indígena mais detalhada do etnólogo diz respeito às pinturas feitas pela nação Kadiwéu que ainda hoje habita, apesar de seus poucos remanescentes, a região do Mato Grosso no Brasil.

Interessado nas manifestações, bem como nos processos que implicavam tais comportamentos, Lévi-Strauss relata não só o que é possível de ser observado diretamente, graficamente sobre os corpos, como também as etapas, procedimentos, sentidos e valores de determinadas ações humanas ${ }^{39}$. A pintura corporal na nação Kadiwéu se dava tanto em ritos pontuais como em situações do cotidiano. Em cerimoniais, contribuía para enfatizar certas passagens da vida, como a transição da infância para fase adulta.

(...) as crianças não eram criadas pelos pais, mas entregues a outra família, e esses só as visitavam em raras ocasiões; ficavam nessa família, ritualmente cobertas de tinta preta da cabeça aos pés (...) até os catorze anos, quando eram iniciadas e lavadas, e uma das duas coroas concêntricas de cabelos que até então formavam seu penteado era raspada. ${ }^{40}$

38 LÉVI-STRAUSS,Claude. Tristes Trópicos. São Paulo, Ed. Companhia das Letras, 1996. 39 Talvez por isto as artes performativas e, de forma ampla, a arte contemporânea se aproximaram intencionalmente da antropologia como o fizeram: Richard Schechner (1954), em diversos estudos; Hal Foster (1955) no texto O Artista Enquanto Etnógrafo (2001); e o artista conceitual americano Joseph Kosuth (1945) no texto O Artista Enquanto Antropólogo (1975), entre outros.

40 LÉVI-STRAUSS, 1996, pp.170. 
Neste ritual o pigmento tem função de delimitar o corpo que na infância esta "aberto", vulnerável, uma proteção da pele e do campo sensível. O simbolismo está na existência da pintura no corpo e no processo cerimonial de eliminá-la. É também uma forma visual de identificação que determina a posição do indivíduo na comunidade.

A pintura corporal da nação Kadiwéu se manifesta em diversos momentos e circunstâncias vividas, mas aqui nos detivemos a este exemplo a fim de contribuir com o sentido geral da presente pesquisa. 


\subsection{Antropometrias da Fase Azul de Yves Klein}
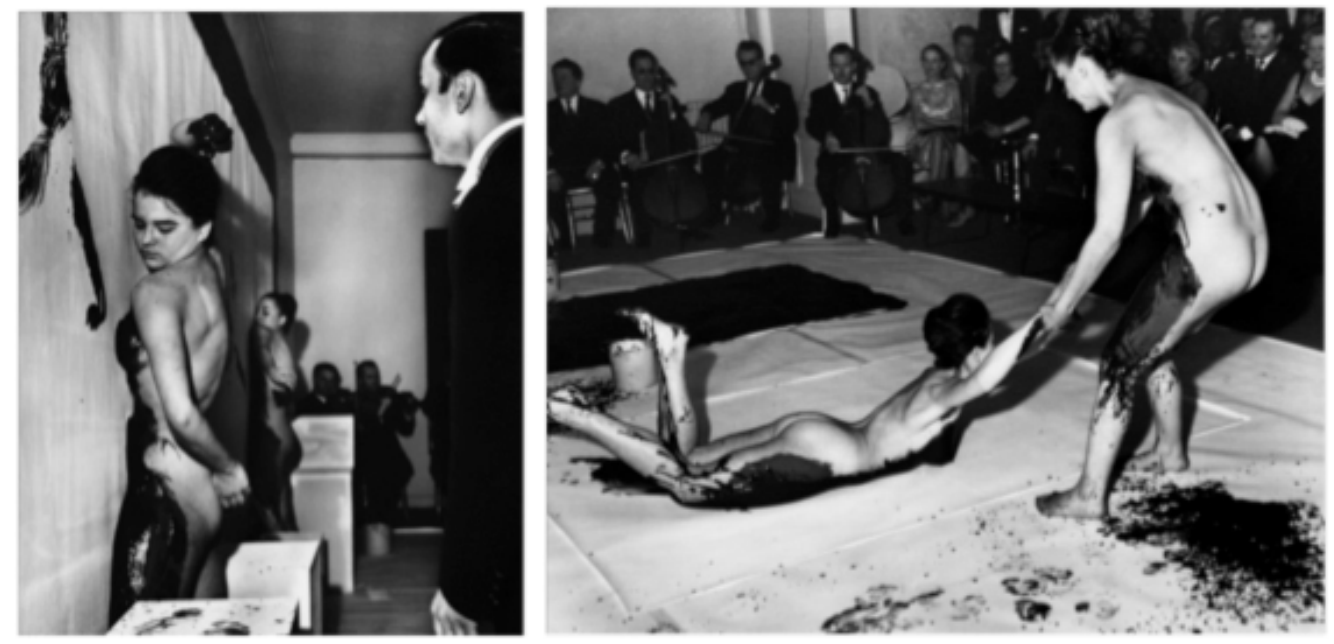

Yves Klein - Antropometrias da Época Azul - 9 de março de 1960

O artista francês Yves Klein (1928-1962), aparece em inúmeras publicações como pioneiro das artes performativas. Foi por meio da cor que sustentou certo questionamento existencial e criador que o acompanhou em toda a sua trajetória: evocou o vazio e paradoxalmente, a presença.

Sua postura diante da vida, sempre crítico e bem humorado, propunha gestos e circunstâncias limites, de cunho metafísico. É icônica a fotomontagem Leap into the Void (1960) publicada no jornal de número único, criado por ele, chamado Dimanche. Na fotografia, que aparecia na primeira página, Klein, num salto alegórico, se joga de um muro alto em direção à rua. No ápice do movimento, congela o instante, suspende: invade o vazio. 


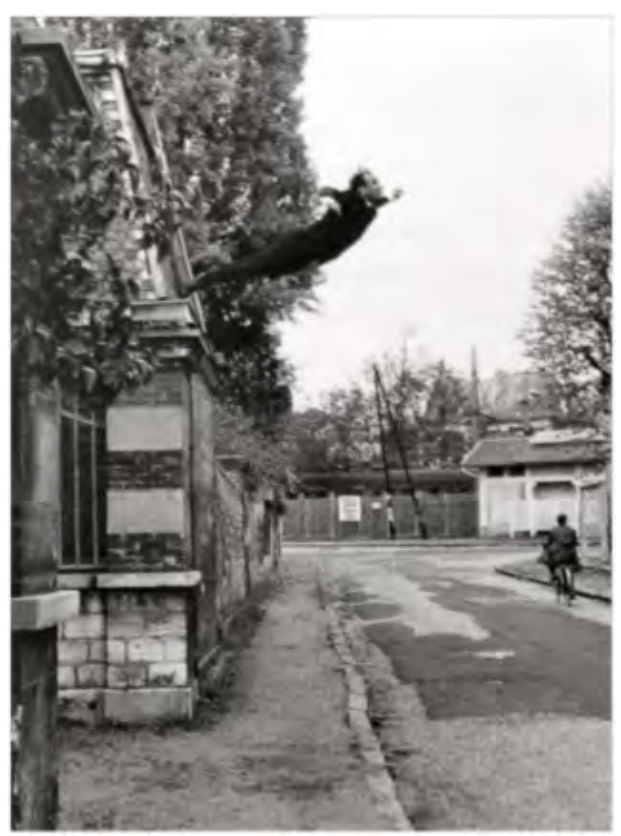

Yves Klein - Leap into the Void - 1960

Nas passagens, dentro e fora, do privado para o público, do material para o imaterial, da vida para a arte, de um para outro campo artístico... $\mathrm{Na}$ pulverização dos limites, Klein evidenciou tanto os processos do fazer artístico quanto seu posicionamento diante do sistema estabelecido da arte.

A opção por não se deter nas linhas e sim na cor e sua materialidade afirmava a idéia de que o espaço e o tempo são um uno: presença, a marca do imediato. "Klein alcançou o sonho de ter apenas cor, sem mediação, em uma intensidade máxima - de tal modo que esta pudesse ser experimentada tão somente no momento, no momento inarticulado da sensação (...). ${ }^{41}$ "

41 BOIS, Yves-Alain. A Relevância de Klein para hoje. ARS (São Paulo) v.8, n.15, p. 54-73, 2010. 
A possibilidade desta presença se efetivar materialmente, enquanto ainda investigava o plano pictórico em si e sua relação com o espaço, estava atrelada a uma pesquisa técnica de como fixar o pigmento puro numa superfície vertical, indo contra a característica orgânica de dispersão das pequenas partículas de pigmento. Bem como de criar uma cor específica, o Yves Klein Blue ${ }^{42}$, que dissesse respeito ao preciso campo de emanações que pretendia evocar.

Nas pinturas monocromáticas, buscava uma singela textura que mimetizava o ondulado causado pela difração atmosférica (como uma miragem). Ao suavizar os cantos e bordas, o efeito cumulativo de pigmento do método de Klein fazia com que a cor ocupasse todo o campo visual, parecendo não acabar abruptamente nas bordas das pinturas mas sim desvanecer.

Para ele, as cores eram como seres vivos, presenças, indivíduos extremamente evoluídos que se assemelhavam às pessoas e a todo o resto. Dizia que haviam nuances que poderiam ser gentis, loucas, violentas, majestosas, vulgares, calmas etc. Dizia que o azul fora escolhido por ter uma "qualidade de estar" característica que lhe conferia uma dimensão inexistente, não mensurável, em suspensão.

Há em Klein, um fundamento específico que o faz estar circunscrito às artes visuais: sua relação profunda com a tradição da pintura, com a cor. Mas, na medida em que os procedimentos e fenômenos passam a lhe interessar, mais e mais sua obra começa a ampliar este campo artístico em outras direções, em experimentações performativas ${ }^{43}$.

42 A fórmula química do YKB (Yves Klein Blue) não foi criada por Klein. Foi produzida por um químico com a instrução de que produzisse uma resina química que fixasse os pigmentos puros sem que perdessem a saturação, a matéria pura da sensibilidade. Klein era fascinado pelos pigmentos puros guardados dentro dos frascos de vidro.

43 O estrato conceitual de Klein era composto por princípios da alquimia rosa-cruz; da filosofia de Gastón Bachelard (1888-1962); da cultura oriental, por meio da prática do judô; e de 
Foi ainda na infância que experimentou imprimir seu corpo com tinta num pedaço de papel... "My hands and my feet dunked in paint, then applied to a surface, and there it was, I was there, face to face with my own psyche. I had proof of having five senses, of knowing how to make myself function!"44.

No final dos anos 1950, depois de investigar a monocromia e conceber o YKB (Yves Klein Blue), decidiu chamar modelos para seu ateliê e iniciar a série de Antropometrias. A partir de comandos vocais, as modelos pintavam os próprios corpos de azul, principalmente a frente do tronco e coxas (que para ele era onde tudo acontecia por si, pela força dos sentidos e do funcionamento do corpo) e então, imprimiam seus corpos sobre a superfície pictórica. Marcas deixadas nas telas eram o rastro de presenças, de acordo com Klein, semelhante àquelas experimentadas em sua infância. $\mathrm{O}$ artista desejava visualizar os fenômenos manifestarem-se por si. De acordo com ele, a manifestação é sempre distinta da forma, é a essência e rastro do imediato.

Seu questionamento era de fato complexo e genuíno mas a temporalidade efêmera evocada por Klein, o instante, quando encontrou o circuito artístico, sofreu desvios que impossibilitavam que a força de seu posicionamento se sustentasse na sua inteireza. O acontecimento foi substituído por espetáculo, por evento ${ }^{45}$.

Foi na década de 1960, na Galeria Internacional de Arte Contemporânea, em Paris, que o artista transpôs suas experimentações privadas, do ateliê, para um ambiente "público". Apresentou as Antropometrias da Época Azul.

ensinamentos do pintor Eugène Delacroix (1798-1963). Ou seja, existiu em sua trajetória o cruzamento de práticas corporais, reflexivas e pictóricas.

44 "Minhas mãos e meus pés mergulhados na tinta, depois aplicados à uma superfície, e ali estava, eu estava ali, face a face com minha psiquê. Eu tive a prova de ter os cinco sentidos, de saber como fazer o meu eu funcionar." KLEIN, 2007.

45 KLEIN, 2007. 
Os corpos de três mulheres foram usados como pincéis vivos para a criação de uma grande pintura que acontecia diante dos olhos do público convidado ao som da Sinfonia Monótona ${ }^{46}$. Klein não tocava nos corpos das modelos, a movimentação delas se dava por comandos vocais. As modelos e o artista praticavam uma telequinésia ${ }^{47}$ perfeita e impecável e foi isto que apresentou.

A relação do corpo do artista com o corpo da modelo vivo, classicamente estabelecido, era então colocado em xeque. Elas não estavam mais para serem observadas e representadas na tela. Eram colocadas na posição de coatuantes, apesar de serem como que objetos moventes, pincéis vivos de acordo com o próprio artista ${ }^{48}$.

O interesse pelo fazer da pintura e a atenção ao instante (da arte, da vida) em Yves Klein deriva, entre outros, do pintor francês do Romantismo, Eugène Delacroix. Este, ao referir-se a idéia de instante na pintura, falava de um bem-estar comparado com aquele que uma pessoa sente quando o corpo está em perfeita saúde. É fugidio. Para Delacroix, necessitamos de uma marca, algo que especialmente nos lembre cada um destes momentos especiais. É então a qualidade do momento que determina o pintor. Assim, produtor de "rastros".

Enquanto no ritual da comunidade Kadiwéu, o corpo era pintado cerimonialmente em determinada fase da vida, dos zero aos quatorze anos, a

46 A Sinfonia Monótona, de Yves Klein, compunha-se de uma única nota tocada durante vinte minutos. Pela constância do som o que se tinha eram as sutis reverberações do tom. A sinfonia era um similar dos monocromos.

47 Telequinésia vem das palavras gregas tele e kinese e significam: mover à distância. Seria então certa capacidade humana, chamada por alguns de paranormal, de mover certas coisas à distância sem tocá-las efetivamente.

48 Esta espécie de desajuste, ou reajuste, interessará o campo conceitual das artes performativas e mais tarde poderemos ver como a Antropometria da Fase Azul apresentada ao público antecedeu obras como Meat Joy de Carolee Schneeman (1964) e os trabalhos com modelos nuas de Vanessa Beecroft (anos 1990). 
marcar passagens, ciclos; em Klein, no contexto da cidade moderna européia, no seu interesse pelo instante, pelo rastro, o pigmento na pele inscrevia-se em circunstâncias fugidias, efêmeras. Esta característica efêmera das Antropometrias da Fase Azul não retira sua qualidade simbólica, mas deixa presente, de maneira inevitável, o pulso, a cadência que organiza o cotidiano moderno. 


\subsection{Roda dos Prazeres de Ligia Pape}
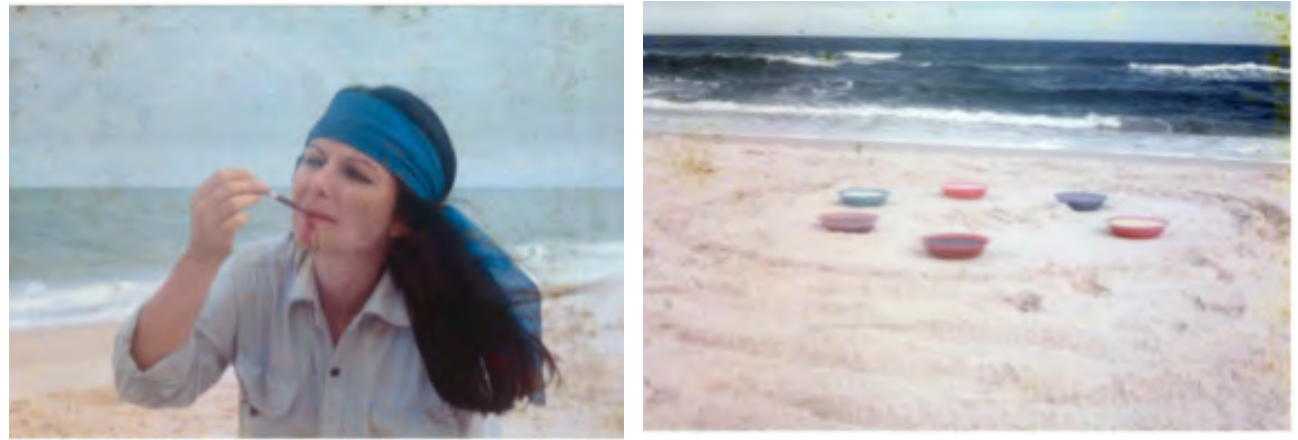

Lygia Pape - Roda dos Prazeres - 1968

Lygia Pape (1927-2004), entre outros artistas, participou na década de 1960, do Movimento Neoconcreto no Rio de Janeiro. Com o desejo de combater a racionalidade e mecanicismo do Concretismo de São Paulo, os cariocas lançaram mão de estratégias sensoriais e fenomenológicas de forma a convocar todo o corpo a participar e ser obra.

O movimento Neoconcreto partia de bases abstratas, geométricas, construtivistas, mas sempre à luz de referências históricas, embasamentos teóricos, experiências vividas e afetos cotidianos que dissessem respeito ao ser de uma forma inclusiva, sensível, total e transcendente; dando margem a desvios, experimentações e transgressões. Numa "vontade de apreender o sentido do mundo ou da história em estado nascente" ${ }^{\prime 49}$. No manifesto do movimento lê-se: 
Malevich ${ }^{50}$, por ter reconhecido o primado da "pura sensibilidade na arte", salvou as suas definições teóricas das limitações do racionalismo e do mecanicismo, dando à sua pintura uma dimensão transcendente que lhe garante hoje uma notável atualidade. (...) Na verdade, Malevich já exprimia, dentro da pintura "geométrica" uma insatisfação, uma vontade de transcendência do racional e do sensorial que hoje se manifesta de maneira irreprimível. ${ }^{51}$

Afirma-se uma visualidade e expressividade propriamente brasileiras no campo das artes, de uma forma ampla, bem como especificamente na Arte da Performance ${ }^{52}$. Foi nas décadas de 1960 e 1970, com o advento da arte conceitual, do feminismo norte americano, do movimento da contra-cultura, entre outros, que de fato institucionalizou-se internacionalmente a Arte da Performance. Daquele momento em diante, principalmente por meio dos textos de Guy Brett, o termo performance passa a se referir também à produção nacional brasileira.

Experimentação, vivência e coletividade foram palavras chaves que impulsionaram e caracterizaram a produção artística do Brasil da época. A imagem da convocação de todos os sentidos corporais, sugeria o viver junto e a criação: dissolvendo hierarquias culturais e desfrutando das cores, das sonoridades, dos cheiros e sabores. A estratégia era viver o grito existencial face ao contexto restritivo da ditadura militar dos anos 1960.

A investigação do cruzamento de sentidos, tato, paladar, audição, ol-

\footnotetext{
50 Kazimir Severinovich Malevich (1878-1935) foi pintor abstrato e fez parte da vanguarda russa e do Suprematismo no início do século XX. Vide imagem da pp.19 da presente pesquisa.

51 GULLAR, Ferreira. Manifesto Neoconcreto. in: PINACOTECA DO ESTADO DE SÃO PAULO - Lygia Pape: Espaço Imantado: catálogo. São Paulo: 2012, pp.80-84.

52 Roselee Goldberg publica nos anos 1970 A Arte da Performance - do futurismo ao presente e inaugura um modo de olhar para a história da arte que coloca foco nas ações dos artistas, nos acontecimentos que estavam junto das obras, como manifestações artísticas relevantes em si. A atora afirma que foi nos anos 1970 que de fato a performance passou a ser aceita como um meio de expressão artística independente.
} 
fato era possibilidade de conhecimento de processos que compõem os corpos. Neste contexto, cada artista evidenciava diferenciações e posicionamentos definidores: Hélio Oiticica (1937-1980) o fez por meio do suprasensorial, atrelado à idéia de percepção total; Lygia Clark (1920-1988) pelo infrasensorial, em que o cruzamento dos sentidos dava-se mais especificamente dentro do corpo; e em Pape, aparecerá por meio do conceito de plurissensorial. "A plurissensorialidade é questão permanente da lógica dos fenômenos de Pape (...). Jogos, falácias da percepção, mutabilidade sensorial montam o quiasma da lógica dos sentidos, jogo entre o invisível e o visível. ${ }^{53}$ "

Pape joga nos interstícios, anda nas beiradas, fala das fronteiras em si enquanto Clark, se volta ao interior, e Oiticica, de certa maneira, ao externo, ao carnaval, aos parangolés... De uma ou de outra forma, atuavam em consonância pensando a arte de maneira sensível, transgressora e investigativa.

A integração do corpo, enquanto materialidade, com o pensamento, atividade imaterial, aparece no trabalho de Pape antes mesmo de fazer parte do movimento Neoconcreto. Sensualidade e contenção já marcavam suas obras, nas quais a sedução não pressupõe excesso, mas silêncio. Há aí referências a passagens, entradas e saídas dos corpos, uma convocação da pele.

Particularmente importante para Pape nestes novos trabalhos era o fato de eles comunicarem idéias "através da epiderme, de uma forma essencialmente sensorial(...) e não pelo discurso formal." $O$ que a artista chamava de epidermização de uma idéia, uma maneira extraordinariamente sucinta de resumir aquilo que pode ser visto como um registro tipicamente brasileiro da relação entre corpo e espírito.. ${ }^{54}$

53 HERKENHOFF, Paulo. Lygia Pape: a arte da passagem. in: PINACOTECA DO ESTADO DE SÃO PAULO, 2012, pp.19-59.

54 OSORIO, Luiz Camillo. Lygia Pape: experimentação e resistência. PINACOTECA DO ESTADO DE SÃO PAULO, 2012, pp.99-115. 
Sua postura não era se deter à pele para circunscrever, fechar, mas desenhar linhas de força, propor encontros de intensidade. Tratava-se de uma afinação da relação corpo-mente que abria possibilidade para o erro, para o acaso, para a estranheza, para o vir a ser, mas com certa contenção já que as passagens interessavam "em si". Limiar ambivalente. "(...) o corpo aparece em Pape de forma mais contida, austera, como força disponibilizadora de movimento, como agente vital que se deixa direcionar. ${ }^{55 "}$

Como ambiente para este tipo de experimentação que propõe balizas mas não conduz racionalmente o fenômeno e sim o acompanha, a cor talvez é índice de transbordamento, possibilidade de comunicação direta, sem palavras, expressão de intensidades diante e avessa às censuras.

Talvez por isso, Pape tenha criado a idéia dos Espaços Imantados que poderiam acontecer em situações cotidianas de maneira espontânea ou intencionalmente. Tratava-se de espaços com força de aglutinação e dispersão, capazes de gerar encontros e criações. Por exemplo as rodas que se formam no centro da cidade quando alguém resolve proferir um discurso, tocar uma música, declamar uma poesia... algo une todos ali e depois de um tempo, acontece uma dispersão e aquele espaço, criado pela reunião das pessoas, se transforma, se dissipa.

Roda dos Prazeres (1968) foi obra que passou por diferentes circunstâncias. No ambiente expositivo Lygia organizou em círculo, no chão, tigelas com líquidos coloridos que deveriam ser degustados. Numa estratégica irônica e crítica havia um "descompasso" entre o prazer visual e o sabor dos líquidos. 
Um amarelo brilhante poderia conter um amargo horrível, um azul intenso poderia gerar dormência na língua...

Propositalmente a obra se realizava na experimentação: depois da cor fazer parte do corpo e os sentidos serem convidados a questionamentos e ao risco. Esta era uma camada do encontro que interessava à Lygia mas havia outra que também levou em consideração e que era fundamento subjacente da maioria de suas ações: a obra poderia ser repetida por quem desejasse, por sua simplicidade de realização. A autoria pode se dispersar horizontalmente.

Para Pape, que caminhava nos interstícios, suas obras aconteciam dentro e fora das instituições. Roda dos Prazeres, numa outra circunstância, se deu na beira do mar (vide imagens no início deste tópico) onde a artista repete a disposição em círculo das tigelas com líquidos coloridos. Cria um espaço imantado de escala individual. Diante da câmera, num exercício de registro de performance, registro de ação, Pape inicia a sua maneira de vivenciar a proposição ${ }^{56}$.

A artista dá voltas ao redor e do lado de fora do círculo formado pelas tigelas e depois entra no centro da roda. Pouco a pouco, entre os tons pálidos da paisagem, do céu azul tênue e da areia da praia clara, pinga em sua língua com um conta gotas os líquidos multicores. A maneira de seu gesto singelo, silencioso e ao mesmo tempo provocativo, sensual, lembra a materialidade de um rito antropofágico. Babas, intensidades, certo estado alucinatório.

56 A instalação de Roda dos Prazeres bem como este registro da ação da artista em vídeo fizeram parte da exposição Lygia Pape: Espaço Imantado na Pinacoteca do Estado de São Paulo, São Paulo, de 17 março a 13 de maio de 2012. 


\section{Dacapo}

Viver a cor, estudá-la, para confirmar a hipótese de que o corpo do artista plástico é composto por características específicas fundamentadas principalmente pela ativação de certo estado perceptivo intersensorial, tátil-visual, foi proposição desta pesquisa.

Ao mesmo tempo experienciar este corpo e ter o distanciamento para falar a respeito foi o grande desafio. Com o desenrolar da pesquisa certas atitudes e desejos revelaram objetivamente que tal estado perceptivo foi incorporado: quietude, vontade de observação, atenção às nuances e envolvimento estreito com a matéria, com o pigmento.

Diferente das artes da cena que com freqüência expunham-me nos palcos, práticas da extroversão, agora, os momentos de compartilhamento deramse em tempos dilatados, espaçados e muitas vezes de maneira indireta, por meio das pinturas, vídeos etc. . De modo mais contido, a respeitar e revelar transformações significativas do corpo-obra.

As artes performativas foram compreendidas enquanto campo de estudos de diminutas ações poéticas do corpo e de questionamentos que aproximam arte e vida. Distanciando-se do espetáculo, a performance, esteve nos gestos e fazeres cotidianos das práticas artísticas instauradas por balizas determinadas para cada ciclo de trabalho.

O encontro com a pintura ao longo desta pesquisa, como laboratório das potencialidades do corpo com a cor, abriu um caminho. Esta prática foi entrelaçada naturalmente ao dia-a-dia de modo cada vez mais intenso. O com- 
portamento dos materiais, de suas fusões e incompatibilidades, trouxe a experimentação para um campo de batalha em que errar era errância: descobrimentos indicados pela materialidade e seus fenômenos.

Terminar o processo com pinturas feitas diretamente com a respiração, com aerógrafo de boca, trouxe a possibilidade de conexão corpo-obra que entendo como um movimento de convergência e síntese de todo o processo.

Minha avó, além das histórias do circo, também pintava, e passei momentos a seu lado, presenciando aquela atividade quase meditativa. Cheiro de tinta-óleo e água raz. Nas entrelinhas das cópias de Almeida Júnior ${ }^{57}$ estavam os pequenos movimentos que revelavam o estar que as palavras não dizem. Foi quem me apresentou o imaginário, a gravidade e beleza do diminuto e, corporalmente, a finitude.

57 José Ferras de Almeida Júnior (1850-1899) foi pintor, do interior do estado de São Paulo, precursor de uma temática regionalista, cultura caipira, na arte acadêmica brasileira. 


\section{Referências}

ARNALD, Jean. Toutch to See. MIT Press, Cambridge, n.114, p. 5/16, Oct. 2005.

BASBAUM, R. Pensar em Performance. MAC-Revista, São Paulo, Museu de Arte Contemporânea, USP nº1, abril 1992.

BATCHELOR, David. Cromofobia. São Paulo: Ed. Senac, 2007.

Colour. Cambridge: Mitt Press, 2008.

BALZAC, Honoré de. A Obra-Prima Ignorada: novela. São Paulo: Ed. Communique, 2003.

BENJAMIN, Walter; et.al. Textos Escolhidos. São Paulo: Editora Abril, 1983. BINSTOCK, Benjamin. Alois Riegl in the Presence of The Nightwatch; MIT Press, Cambridge, n.74, p.37-44; fall, 1995.

BOIS, Yves-Alain. A Relevância de Klein para hoje. ARS (São Paulo), v.8, n.15, 2010.

; Krauss, Rosalind E./ Formless - a user's guide. Cambridge: New York Zone Books, 1997.

BRETT, Guy. Brasil Experimental, arte/vida: proposições e paradoxos. Rio de Janeiro: Ed. Contra Capa, 2005.

CHIPP, H.B. Teorias da Arte Moderna. São Paulo: Ed. Martins Fontes, 1999. COHEN, Renato. Performance como linguagem. São Paulo: Editora Perspectiva, 2002. Coleção Debates.

Work in Progress na Cena Contemporânea. São Paulo:

Ed.Perspectiva, 1997. 
CRARY, Jonathan. Techniques of the Observer. MIT Press, Cambridge, n.45, p.3-35; summer, 1988.

DELEUZE, Gilles. Francis Bacon - Lógica da Sensação. Rio de Janeiro: Ed.Zahar. 2007.

DEBORD, Guy. A Sociedade do Espetáculo - Comentários sobre a Sociedade do Espetáculo. Rio de Janeiro: Contraponto Editora, 1997.

FIGUEIREDO, Luciano. Lygia Clark - Hélio Oiticica - Cartas (1964-1974). Rio de Janeiro: Ed. UFRJ, 1998.

FOCILlON, Henri. Elogio da mão. Revista Serrote, São Paulo, n.6, p. 7-31, nov. 2010.

FOSTER, Hall. Modernizing Vision. Seatle: Bay Press, 1988.

The Return of the Real: the avant-garde at the end of the century. Londres: The MIT Press, 1996.

FUndAÇÃO BIENAL DE SÃO PAULO. Como Viver Juntos. Catálogo de textos da 27a Bienal de São Paulo. Curadoria de Lisette Lagnado; co-curadores Adriano Pedrosa, Cristina Freire, José Roca, Rosa Martinez; curador convidado Jochen Volz. São Paulo, 2006.

GALARD, Jean. A Beleza do Gesto. São Paulo: Edusp, 1997.

GIANNOTTI, Marco. A imagem escrita. Ars. (São Paulo), v.1, n.1, p. 91-115, 2003.

GOETHE. J.W. Doutrina das Cores. Tradução Marco G. Giannotti. São Paulo: Editora Nova Alexandria, 1993.

Goldberg, Roselle. A Arte da Performance: Do Futurismo ao Presente. São Paulo: Ed.Martins Fontes, 1979. 
Live Art since the 60's. New York: Thames \& Rudson, 2004.

Glusberg, Jorge. A Arte da Performance. São Paulo: Ed. Perspectiva, 1987.

HEINDEL, Max. Conceito Rosacruz do Cosmos. São Paulo: Fraternidade Rosacruz, 1961.

Hildebrand, Adolf. The Problem of Form in Painting and Sculpture. Londres: G. E. Stechert \& Co, 1907.

IVERSEN, Margareth. Alois Riegl: Art History and Theory. Massachusetts: The MIT Press, 1993.

JONES, Amelia. The Artist's Body. Londres: Ed. Phaidon, 2000.

KANDINSKY, Wassily. De lo Espiritual en el Arte. Buenos Aires: Ed. Galatea Nueva Vision, 1056.

KAPROW, Allan. Essays on the Blurring of Art and Life. Londres: University of California Press, 2003.

KLEIN, Yves. Overcoming the Problematics of Art. Paris: Spring Publications, 2007.

LÉVI-STRAUSS, Claude. Tristes Trópicos. São Paulo: Ed. Companhia das Letras, 1996.

LANT, Antonia. Haptical Cinema; MIT Press, Cambridge, n.74, p.45-73, fall, 1995.

MELIM, Regina. Performance nas Artes Visuais. Rio de Janeiro: Zahar Editora, 2008.

MERLEAU-PONTY, Maurice. Fenomenologia da Percepção. São Paulo: Martins Fontes, 2006. 
O olho e o espírito. São Paulo: Ed. Cosac \& Naify, 2004.

NOVAES, Adauto (organizador). Arte Pensamento. São Paulo: Ed. Companhia das Letras, 1994.

O'DOHERTY, Brian. No interior do cubo branco - A ideologia do Espaço da Arte. São Paulo: Ed. Martins Fontes, 2002.

OITICICA, Hélio. Aspiro ao Grande Labirinto. Rio de Janeiro: Ed. Rocco, 1986.

OlAIO, António. Ser um Indivíduo Chez - Marcel Duchamp. Porto: Dafne Editora, 2005.

PATERSON, Mark. The Senses of Touch - haptics, affects and technologies. Oxford: Ed. Berg, 2007.

PINACOTECA DO ESTADO DE SÃO PAUlO. Lygia Pape: Espaço Imantado: catálogo. São Paulo, 2012. 387 p. Catálogo da exposição de Lygia Pape com Curadoria de Manuel J. Borjas Villel e Teresa Velásques; textos de Paulo Herkennhoff... (et al). Exposição realizada de 17 de março a 13 de maio de 2012, na Estação Pinacoteca.

RAMIREZ, Mari Carmen. Hélio Oiticica - The Body of Color. London: Ed. Tate Publishing, 2007.

RANGEL, Lenira. Dicionário Laban. São Paulo: Annablume, 2005.

RIEGL, Aloïs. Excerpts from The Dutch Group Portrait; MIT Press; Cambridge, n.74, p.3-35, fall, 1995.

Late Roman Art Industry. Italia: Giorgio Bretschneider Editore, 1985.

SARDO, Delfim. Quando a Arte fala Arquitectura. Marte 4: da criação artís- 
tica à intervenção espacial, Lisboa, n.4, p. 74-87, 2011.

SENNETT, Richard. O Artífice. Rio de Janeiro: Ed. Record, 2009.

SHUSTERMAN, Richard. Pensar através do corpo, educar para as humanidades: um apelo para a soma-estética. Marte: De que falamos quando falamos de performance, Lisboa, n.3., 2008.

SMITH, Pamela H. The Body of the Artisan - art and experience in the Scie-tific Revolution. Londres, University of Chicago Press, 2004.

SOARES, Carmen Lúcia. Imagens da Educação no Corpo: estudo a partir da ginástica francesa do século XIX. Campinas: Ed. Autores Associados, 2002.

VALERY, Paul. Degas Dança Desenho. São Paulo: Ed. Cosac \& Naif, 2003.

VARICHON, Anne. Colors - what they mean and how to make them. New York: Ed. Abrams, 2006. 
Parte III 


\section{Anexos}

6.1. ANEXO 1 - Entrevista com a artista Monica Nador (JAMAC - Jardim Miriam Artes Clube - São Paulo, 6 de outubro de 2011).

\section{Apresentação:}

Monica Nador (1955) é artista plástica, pintora, desenhista e gravadora, formada pela FAAP (Fundação Armando Álvares Penteado) em 1983. Foi aluna de Regina Silveira entre outros. Participou de diversas exposições no Brasil e exterior. Com o projeto Paredes Pinturas passou a atuar em comunidades diversas, realizando trabalhos de pintura coletiva. Recebeu titulo de mestra pela Universidade de São Paulo em 2000.

FSM: Fabíola Salles Marino

MN: Monica Nador

FSM: Como é chegar numa comunidade que você não conhece muito bem e instalar ali um projeto de arte? Como foi que se aproximou das pessoas?

MN: Quando eu vim aqui pro Jardim Miriam vim porque tinha uma ONG aqui chamada Arte de Despertar da Milu Vilela. Então eu trabalhei nesta ONG. Estava voltando do Insight, uma exposição em Tihuana, já sabia que queria morar na periferia. Meu objetivo era ficar um ano inteiro, sabia que deveria ser uma residência maior. Naquela ONG estava começando uma relação mas depois de três meses, fui mandada embora. Naquele momento cortei um monte de relações que eu não queria ter cortado com as pessoas daqui. Então eu decidi que seria o meu próprio patrão e resolvi fazer uma ONG . 
FSM: Naquele momento você já conhecia um muita gente do Jardim Miriam, não?
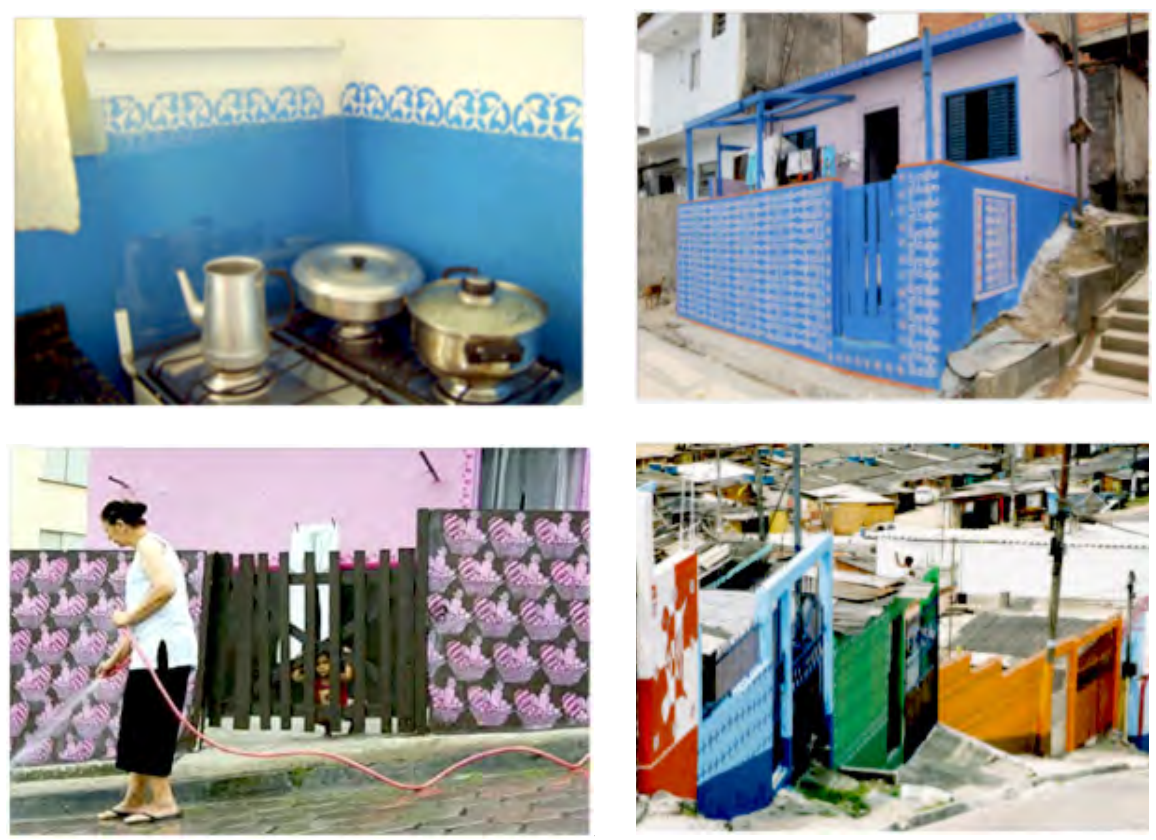

Monica Nador - Projeto Paredes Pintura em diversas localidades

MN: Quis ficar aqui por causa destes laços que já tinha começado a fazer, mas só que demorei tanto pra voltar - um ano e meio - e na hora que eu consegui me restabelecer, reencontrei pouca gente. Outro ponto importante quando resolvi ficar aqui no Jardim Miriam foi que eu me aproximei de uns amigos que são ligado à uma rede que se chama Consulta Popular. É um coletivo de movimentos sociais (MST, movimento das barragens, moradia, Passe Livre, Educafro...), muitos são membros fundadores do PT, são representantes de diversas lideranças espalhadas pelo Brasil. Eu falei para eles que queria ir para o Jardim Miriam e perguntei com quem que poderia falar. Me ajudaram. Estes amigos dão um grande incentivo para o projeto até hoje. Foi por muita insistência da minha 
parte eu fui me aproximando. Eu queria muito. De quinze em quinze dias eu me reunia com eles. A gente ficou pelo menos um ano se encontrando antes de estabelecer mesmo o projeto aqui.

FSM: Mas você se relacionava diretamente com as pessoas da região?

MN: Então este grupo com quem eu me encontrava era formado pelas lideranças. O que eu estava querendo era articular um grupo de recepção e conexão. Bem, eu já fazia este trabalho no bairro reunindo pessoas para pintar mas o que eu queria fazer era o Paredes Pintura e aí, outras pessoas vieram e acharam legal, participaram. Também este povo não durou muito tempo. Porque é duro o trabalho. Então foi assim que eu fiquei, vim atrás destas pessoas e elas vieram me introduzindo. É difícil mudar de tribo...

FSM: Acredito que não necessariamente você vai para um lugar, propõe algo ali, e este movimento é frutífero para tal comunidade. Comente.

MN: É, não, mas você pode ter certeza que vale. É uma opção para quem quiser. O que a gente não pode é se furtar. Porque a gente precisa trabalhar com educação em vários níveis. Conviver, mostrar exemplo, isto é educar. Precisa confiar que você pode estender a mão para os outros sim. Porque o mundo é contra, sabe, então você precisa acreditar.

FSM: Você acha que a cor teve um papel afetivo como aproximação? MN: Eu acho que sim, claro. Claro, lógico que é. É só o afeto que me move. Antigamente quando eu não trabalhava com a sociedade como um todo eu me 
sentia dividida, incompleta, doente, sabe?

FSM: Depois do primeiro momento de aproximação, acredito que o trabalho deve ter promovido um impacto e uma alteração significativa no cotidiano das pessoas, como se deu a continuidade? Foi espontânea a participação da comunidade?

MN: Por exemplo o Mauro, que é uma referência do bairro, um dos primeiros que eu me aproximei. Ele foi metalúrgico, tem trinta anos, fez ciências sociais e é professor de geografia. É uma pessoa maravilhosa. Quando eu cheguei aqui ele falou: olha o seu trabalho é muito legal mas o que eu quero mesmo, o que eu gosto, é educação continuada. É por causa dele que nós temos o Café Filosófico. Um encontro que vem monte de gente legal conversar uma vez por mês. O Mauro era militante principalmente da área da saúde mas depois de um tempo aqui no JAMAC a cultura também entrou no elenco de reivindicações dele. A outra coisa interessante é que eu cheguei na casa dele outro dia e ele tinha pintado as paredes de dentro. Tudo listradão. Aí eu falei: Uau Mauro! Uma liberdade, sabe? Muito legal. Ele acompanha o projeto desde o início, é super próximo. Ele quer que a gente organize aqui uma Bienal do Jardim Miriam.

FSM: Quais atividades acontecem aqui neste momento?

MN: Estamos preparando trabalhos para a exposição que faremos na galeria Luciana Brito em novembro. Tem o trabalho na CDHU (Companhia de Desenvolvimento Habitacional e Urbano) em Cubatão de pintura de paredes. Os Cafés Filosóficos que são encontros mensais e fazem parte da programação do Ponto de Cultura. E o Ponto de Cultura oferece desenho animado, já tivemos cinema, 
umas palestras e as aulas de estêncil.

FSM: Vocês já fizeram algum tipo de atividade corporal aqui?

MN: Sim, fizemos. Eu tenho uma irmã que ela fez uma sessão de psicodrama.

Foi apenas uma vez, foi legal mas não continuou.
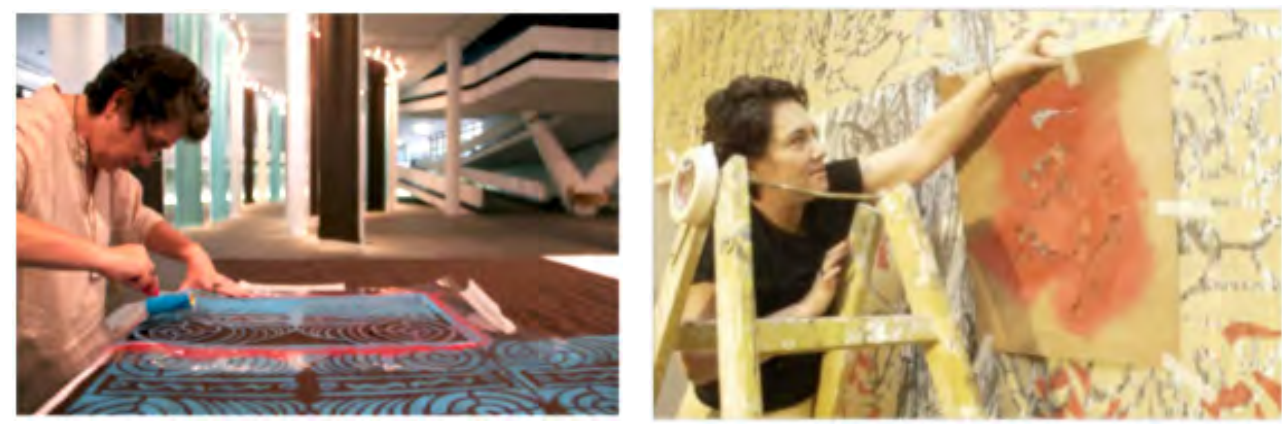

Imagens de Monica Nador trabalhando

FSM: E tem outros artistas aqui na região? Eles participam de alguma forma? Existe alguma troca com eles?

MN: Tem, claro que tem. Já vieram muitos grafiteiros aqui. Até algumas pessoas já falaram que notaram certo refinamento do trabalho destes grafiteiros daqui. Alem disso, um dos meninos que está comigo é artista, o Paulinho. Agora mesmo fez um daqueles rinocerontes que tem pela cidade. Fez a vaca e foi leiloada a vaca dele. Além do Bruno Perê. E na época da 27 Bienal fizemos aqui uma exposição com os pintores da região

FSM: Pode comentar a respeito da relação entre arte e vida?

MN: Arte é uma bobagem. Eu fico me perguntando: O que eu faço? O que é arte? O que eu faço é artesanato, a pintura como um artesanato chiquérrimo. A arte é uma construção social. Uma construção artificial. 
FSM: Você é semente, né?

MN: Sou, eu sou. Se Deus quiser.

Observação:

Neste momento ela sugeriu que assistíssemos a um pequeno filme http://www.videolog.tv/baroukh/videos/428827 produzido pelo Centro de Cultura Judaica de São Paulo, Casa de Cultura de Israel, em 2009, dentro da série Ensinar e Aprender Arte Contemporânea. Segue abaixo a transcrição do que a artista fala no filme que se torna relevante aqui como ilustração e contextualização da conversa.

"Eu sou pintora de formação. Numa certa altura na minha vida de pintora eu voltei a estudar, fui fazer pós graduação e li um texto que mudou a minha vida, mudou a minha cabeça, tive uma crise que me deixou dez anos sem pintar telas. Eu me deparei neste texto com a realidade nua e crua de que a pintura já era. O que quer dizer isto? Quer dizer que a pintura já era dependendo do que você espera dela. E eu que queria fazer a revolução, achei muito pouco pintar e achei que deveria fazer de outro jeito. Então eu fui convidada pelo Museu de Arte Moderna para pintar uma parede, fazer uma grande pintura mural. Eu fiz a pintura mural e aprendi a técnica do estêncil com um grafiteiro que me ajudou a fazer a parede. Fiz a parede. Quando eu dei conta de fazer a parede pensei: então vamos pintar paredes mais necessitadas de pintura do que esta bela parede do MAM (Museu de Artes Moderna). Foi um pouco isto que aconteceu.

Minha intenção era pintar lugares que não tinham acesso àquele tipo de informação. Vamos dizer que eu queria que a arte fosse mais democrática. E fui pintar nas periferias. Resolvi pintar as casas mas eu fui me envolvendo muito 
com o trabalho social. Eu queria realmente que tivesse uma ação mais concreta. Eu não poderia ficar a mercê das exposições me chamarem para eu poder pintar uma casa a mais. Quer dizer, eu poderia, mas não era isso que eu queria. Eu na verdade, o que eu mais queria, era que o meu trabalho virasse política pública.

Eu tenho um objetivo de me ligar a realidade onde estou, é um objetivo irremovível pra mim. Durante muito tempo eu achei que iria abandonar totalmente o circuito de arte mas eu vejo que isto não é possível. Não é possível e eu não quero. Eu preciso do reconhecimento público para eu fazer o trabalho, pra conseguir as coisas. É muito difícil começar a fazer um trabalho deste tipo.

Arte é uma coisa que historicamente sempre esteve ligada ao cotidiano das pessoas, a vida do dia-a-dia, faz parte do ser humano ser artista. Na préhistória os caras desenhavam os bichinhos que eles queriam caçar ou que eles queriam oferecer para divindades, quer dizer, este registro sempre existiu da gente mexer com a forma plástica, cerâmica... isto sempre existiu. Esta coisa de Arte Contemporânea, quem fez foi o iluminismo, esta concepção que tem duzentos anos.

Quando eu li isto naquele texto do Douglas Crimp ${ }^{58}$, que a arte do jeito que a gente conhece hoje só tinha duzentos anos, eu fiquei louca. Faz duzentos anos que os caras estão cortando a onda da arte. Eu dou o maior valor para esta instância da produção humana que é o artesanato. E eu acho que a pintura é um artesanato chiquérrimo. Sabe? Não é muito mais do que isso. E não que precisasse ser, e não que isso seja pouco, inclusive. Mas não venha me dizer que pintura é uma coisa e que artesanato é outra... estou fora. Isso é modernidade. 58 CRIMP, Douglas. Sobre as Ruínas do Museu. São Paulo: Ed. Martins Fontes, 2006. 
Eu sou uma artista muito tradicional.

(...) O JAMAC, Jardim Miriam Arte Clube, está aqui desde 2004. Quando eu vim para cá eu trouxe alguns amigos que não agüentaram muito a barra, foram embora e eu fiquei. Porque na verdade eu tinha este desejo de vir morar numa periferia aqui em São Paulo há muitos anos. Na verdade era um desejo meu. Hoje é gerido como uma OCSIP (Organização da Sociedade Civil de Interesse Público), e é basicamente o meu ateliê que é aberto ao público aqui da periferia. O JAMAC virou um dos pontos de difundir conhecimentos inacessíveis para as camadas populares aqui na região. Mas eu pretendo que aqui a gente seja um lugar formador de arte educadores para a região. Quer dizer, aqui é muito mais difícil mas é muito mais vivo, muito mais gostoso, eu sinto um prazer imensamente maior." 
6.2. ANEXO 2 - Conversa com o bailarino e professor da técnica de Feldenkrais José Maria Carvalho. São Paulo, 17 de março, de 2012.

Apresentação

José Maria Carvalho é bailarino, coreógrafo, professor e pesquisador de dança butô, dança contemporânea e danças brasileiras. Estudou com Klauss Vianna, trabalhou com Roberto Freire e Mirian Muniz e fundou, em 1985, o Espaço Viver Dança e Cia., em São Paulo, onde é diretor e professor. Formado no método Feldenkrais de Educação Somática pela Associarão Feldenkrais do Brasill. Sua pesquisa atual busca parâmetros corporais próprios a partir da dança contemporânea e do butô.

FSM: Fabíola Salles Marino

JMC: José Maria Carvalho

FSM: Esta conversa teve como intento levantar pontos que dizem respeito ao corpo do artista, seu fazer e fazer-se, a partir das experiências e vivências do bailarino e pesquisador José Maria Carvalho. Veremos como aborda as composições que estabelece com pensadores e criadores, Moshe Feldenkrais, João Guimarães Rosa, Takao Kosuno, entre outros, bem como princípios que considera fundametais na trajetória de um corpo criador.

JMC: Falarei de um recorte, um corte, da minha passagem pelo método Feldenkrais. Traduzir é sempre recriar e necessariamente já se tem um ponto de vista. Eu entendo que quando trabalhamos com a obra de alguém, criativamente, não trabalhamos com aquilo que aquela pessoa explicitou, com o que está escrito, ou atualizado. O que entra em contato com aquele texto é o meu racional, e eu decodifico aquilo lá. Mas eu também, através do pensamento, entro em contato com um contexto maior daquela obra, que são suas potências, que é o virtual 
daquele pensamento. Que não está atualizado naquele texto. É apenas uma parte, como um iceberg, uma parte é visível e outra parte existe ali e não está explicitado. E é desta forma que eu acredito lidar com o pensamento de outras pessoas.

A minha força ao se compor com a força daquele pensamento, captura coisas que de lá criam potência para mim e que eu trago no meu trabalho. Mergulhar neste virtual, na força do seu encontro com aquilo, esta para mim é a riqueza das obras que são plenas. É um território tão vasto que cada um consegue conectar a sua singularidade com algo dali e trazer toda uma reflexão. Um outro já está fazendo outra e abre-se caminho para muitas conexões diferentes que estão ali e ainda poderão ser feitas.

Se não, eu cristalizo e trato como algo muito frágil. Ao dizer, por exemplo: Feldenkrais pensava assim. O pensamento dele me atravessa, me permeia. Há certos momentos em que eu já não sei mais se este pensamento é do Feldenkrais, do Guimarães Rosa, do Artaud... Meu, eu sei que não é. Esta é única coisa que eu sei.

Eu acho que a gente não inventa nada de novo. O criativo é a maneira de você entrar em contato com um material e trazer à tona coisas. Mesmo porque, aquele autor também não inventou tudo aquilo, ele fez o mesmo trabalho criativo, foi beber em um monte de outras obras, num virtual de um monte de coisas. Feldenkrais diz isto e o Guimarães diz: eu não inventei as coisas, elas estavam aí, eu só tive a capacidade de ir lá e trazer.

Só que nem tudo está explicitado. Tem gente que diz: mas aonde que está o texto que diz isto? Aonde está o pulo do gato? E não há. É você quem 
vai fazer o pulo do gato. Porque na hora em que você se conectar fundo com aquilo, acontece algo criativo. E alguém virá falar, ah, da onde que ela tirou isto, tem um lugar que ela escondeu e não está mostrando para ninguém...

Feldenkrais diz, eu fui lá e tirei, tirou porque estava envolvido, estudando e pensando. E outro alguém que tiver um mesmo grau de envolvimento vai lá e vai tirar alguma coisa que está ali. Cada um vai tirar, então veja, isto é infinito, uma multiplicidade.

Na época do Feldenkrais tinha o Frederick Matthias Alexander, a Gerda Boyesen, a Ida Rolf, todos contemporâneos, com certeza ele leu e conhecia o trabalho destas pessoas. Mas em algum momento ele partiu para um olhar original dele. Firmar um olhar dele que não era o da Ida, do Alexander... Cada um criou uma abordagem muito própria, da sua singularidade. A Ida Rolf era química, bioquímica, e ela estava muito interessada nos tecidos, nas fascias. Então ela investiga a mudança daquele tecido e cria uma abordagem que mexe e muda as composições dos tecidos. Seu caminho de pesquisa é o de liberação destes tecidos e fluxos do corpo. A fascia diz respeito às trocas do mundo com você e de você com o mundo, faz um meio de campo. É um lugar muito importante e ela olha para isto.

Então cada um tem um olhar singular. Para questões que aparecem numa certa época e como é que aborda aquilo. A diferença é que Feldenkrais era físico, teve um problema nos joelhos e ficou bastante motivado diante desta impossibilidade para encontrar caminhos para a questão. Foi então pesquisar, estudar e ver como abordar de maneira diferente do que os médicos naquele momento apresentavam. Diziam que seria um processo final, de degeneração: 
olha, você só vai piorar e uma hora morrer. E para ele não, ele tinha uma visão dinâmica. Ele então diz: você sempre pode melhorar. Estava querendo não o certo e o errado mas como você pode melhorar. Não importa a questão, não importa certo e errado, importa que você pode melhorar. Não importa de onde vem a questão.

E ele começou a trabalhar ferramentas e procedimentos para que se pudesse melhorar partindo da seguinte constatação: nós usamos muito pouco do nosso potencial. A vida cotidiana, a vida social, nos leva a um uso muito limitado da nossa potência. Então ele pensava que era possível uma melhora. Na medida em que você trabalha a sua potência as suas questões, as mesmas já se recolocam dentro disso. Clinicamente eu percebo que quando a pessoa traz uma questão, ela está paralisada ali.

Quando uma pessoa traz para uma dinâmica de vida algo cristalizado, quando se coloca em movimento, suas questões também se recolocam. Então não se trata de eu ter um problema que vou curar. Mas olhar como eu tenho questões na minha vida que estão paralisadas e como é que eu penso a minha vida como uma dinâmica, um processo e como eu recoloco estas questões dentro destes processos, boto tudo pra andar junto. Eu leio isto no Feldenkrais, apesar de não estar colocado exatamente desta maneira em seus poucos escritos.

E pode ser não só no seu corpo mas na sua casa. Se a energia da casa está parada, alguma questão da pessoa também está parada. A casa, o quarto, a planta, a cozinha, o cachorro, tudo está na dinâmica da pessoa. Então olhe bem para o ambiente em que você está que isto tem a ver com o seu corpo tam- 
bém. Coloque a energia para circular, mexa, troque a cor, tire a poeira, mude. A estereoscopia, por exemplo, é uma realidade, está ali, mas muita gente não consegue ver. E se a pessoa insistisse um pouco mais conseguiria ver pois esta é uma capacidade de todo mundo. Ou seja, o que você precisa ver está ali, precisa assim, encontrar uma maneira de enxergar aquilo.

Mesma coisa quando as pessoas falam do Butô. O que o Takao traz é o mesmo que o Kazuo Ohno ou o Hijikata estavam falando em suas danças, em seus procedimentos artísticos, e que Proust falará literalmente como um pensador. A idéia de que no mesmo momento em que o artista está criando a obra, está criando o sujeito artista, está trabalhando nesta questão. Por isso que vida e obra se cruzam ali. Elas têm uma interface. Porque você não cria a obra se não estiver criando as condições para a criação daquela obra, que é a criação deste sujeito que cria a obra.

E este sujeito que cria a obra, não é o sujeito de um corpo cotidiano. Então quando a gente fala do corpo do artista talvez aí a gente possa fazer um link. Esta é uma questão para mim importante. Quando a gente entra para fazer uma improvisação não é com este corpo da rua. Este corpo é um corpo que eu só apresento marcas, hábitos e clichês. É um corpo que só consegue trazer o que já está marcado aí, não consegue trazer nada nestes primeiro momento a não ser que entre num processo e comece a arrebentar com isso. Arrebentar não sei se é a palavra mas talvez: limpar. Até que você possa deixar que outras trilhas, que outras potências apareçam ali. Se não, num primeiro momento, eu só posso falar do que já existe, fazer composição com o que já existe.

Este corpo criativo por exemplo, para Takao na dança butô, você ex- 
perimenta no seu cotidiano e por isto ele dizia: olha, nesta loucura de trabalho, a gente não chega ao poético. Está no meio desta loucura? Para. Cancela. Vai ao parque e escreve um poema. O que ele estava dizendo é que no movimento utilitário cotidiano não vai poder emergir o poético. Eu não sei como é isso em artes plásticas mas quando você olha o pintor Francis Bacon surge uma questão interessante. Bacon dizia o seguinte: quando eu pego uma tela vazia alí só tem clichê: o clichê que estava nele como pintor, o ateliê estava cheio de clichê e o quadro também estava cheio de clichê. Então quando eu chego para pintar ali eu chego para pintar o clichê.

Assim o primeiro procedimento todo que eu preciso realizar é limpar a tela, me limpar, para poder começar. Eu tenho todo um trabalho de limpeza, de sair disso daí. Então nos procedimentos antes da gente querer improvisar tem um trabalho longo de sair deste corpo cotidiano e quase como um xamã chamar as entidades ("estou brincando"). É um trabalho de limpar, de quebrar com os clichês e dilatar energias que estão em mim para que o corpo possa estar num lugar mais distanciado de tudo o que é mecânico do cotidiano, com outras trilhas abertas, para poder trabalhar e criar.

O que estamos chamando de vida, no cotidiano social, na verdade temos pouco espaço para que a gente possa vivê-la. É fundamental que o artista possa levar para o cotidiano esta vida o quanto for possível. Isto que o Takao dizia que era o sujeito artista. Esta é a grande batalha. A grande batalha que você está dizendo e que o Takao dizia é que o sujeito artista é aquele que vai levar para a vida dele esta experimentação. O que a gente está dizendo é que na vida social, cotidiana, a gente tem pouco espaço e oportunidade de viver isto porque 
o que a maioria diz é o seguinte: eu não tenho tempo, eu preciso trabalhar, eu preciso sobreviver. Todo mundo dá esta desculpa, ao invés de falar: não, vamos ficar aqui, dilatar... Mas e aí, como eu faço para romper com estes compromissos?

Por exemplo a vida da Leila Diniz. Ela foi quase presa pela ditadura porque diziam que era revolucionária, não uma revolucionária dos modos da esquerda que queria pregar a revolução. Ela não pregava a revolução, ela era a revolução na vida dela. Isso criava um incomodo muito grande por exemplo com os parceiros dela. Estava com um, largou este, ficou com um outro... a vida dela fluía com intensidade. E aí a sociedade fala: ela é puta. E depois ela vira uma atriz famosa aí não é mais puta, é liberta, entende? Ela é uma pessoa que nunca manteve a aparência. Foi a primeira pessoa que apareceu com um biquíni e uma super barriga na praia. Com aquilo consideraram-na uma devassa. Veja, hoje em dia, qualquer grávida vai de biquíni na praia. Mas tinha esta pressão social. Quando a ditadura a prende, ela fala: eu não quero fazer revolução nenhuma, eu quero é viver em paz, me deixem em paz, eu quero é ser livre. Para a ditadura, ela era uma revolucionária mas ela de fato queria criar, era uma atriz, falava o que pensava. Ela não queria ter restrições para ser o que ela era.

Depois é até idolatrada mas na hora é marginalizada, punida... Tem que negar-se. Cientistas por exemplo, tiveram que negar suas obras pois contradiziam tudo que havia sido dito antes. Milhares de mulheres foram mortas como bruxas na fogueira porque pensavam e falavam o que pensam. Todos estes são sujeitos artistas. São pessoas que tinham uma prática de vida, que afirmava al- 
guma coisa, e que incomoda de mais.

Eu acho que quem consegue levar isto para a vida é muito difícil porque você vai sofrer uma pressão de todo mundo: da família, dos amigos, da sociedade em geral, da imprensa. Na nossa vida, a qualquer momento que você assumir um caminho único e que você tiver força neste caminho, de algum lugar uma cacetada virá. Porque a sociedade não agüenta. Ela vai assimilando pouco a pouco, com o tempo.

Com o Takao isto foi um grande aprendizado. Então a gente tinha a hora de começar o ensaio e não tinha uma hora marcada para terminar o ensaio, nunca teve. Então quando ele chegava era a hora de começar o trabalho e, terminava, na hora que o trabalho terminasse. Muitas vezes saia lá pela uma da manhã.

O Takao tinha a capacidade de habitar a intensidade. Eu chamo do rigor extremo das coisas. Nada é gratuito absolutamente nenhuma coisa é gratuita. E isto eu acho que é um primor da contribuição dele. Porque cada singularidade de cada artista traz um mundo... Proust fala: cada um traz um mundo possível à tona. Que se você não for lá para ver nós não o teríamos. Isto é que é lindo. Esta seria uma missão (se é que eu posso falar que o artista tem uma missão) que ele traz à tona alguma coisa que só ele pode trazer e que se ele não o fizer ela não virá. Porque só ele pode trazer, porque é singular. Isto é muito lindo. Isto fazia com que ele tivesse esta potência de tirar de cada artista a sua singularidade.

A experimentação cria um corpo singular que se expressa ou expressa este corpo de uma maneira singular. Então só existe uma luva para cada mão e uma mão para cada luva. Duas mãos não caberiam na mesma luva neste caso. 
Para cada linguagem, cada expressão, um corpo. Muito singular.

Então surgiu nesta nossa conversa um lugar. O corpo deste artista que ao viver a arte como destino, como desejo, está vivendo num lugar em que na medida em que ele cria o seu corpo, cria. Acho que é deste campo que você está falando na sua pesquisa, deste artista que você está falando. Como é que este artista conectado com o seu destino, com o seu desejo, a arte cria corpo nele e o corpo expressa a arte dele. Expressa aquela alma que está ali, aquela subjetividade. E como no desejo de expressão que esta alma tem ela necessariamente cria um corpo, um substrato para que isto possa se materializar. O corpo neste sentido é este material, esta matéria, é corporificação desta subjetividade. E esta subjetividade é fruto dos encontros deste destino. Porque todos os encontros mudam o interno, ele vai se ampliando, e chega uma hora que aquele corpo não dá mais conta... esta criação vai criando corpo e este corpo vai se expressando e isto é eterno.

E aí é muito lindo pensar isto no ponto de vista das cores. Na idéia do ferreiro fica muito claro isto, ele não simplesmente bate o ferro, o ferro bate o corpo dele também. E isto é fazer corpo. Aquele ofício cria corpo ao mesmo tempo que aquele corpo interage com aquela matéria e espiritualiza aquela matéria. Veja, é ferro mas de repente, é Escalibur. Aquilo é mais do que um ferro fundido, aquilo já tem signos ali. Já está espiritualizado aquilo ali de alguma maneira. Tem umas espadas dos samurais clássicas que eram forjadas por uns artesãos especiais que faziam ligas especiais que tinham todo um procedimento... era uma arte tremenda. Tinha um balanço perfeito. Era um ser que nasceu ali, entendeu? 

